\begin{tabular}{|c|c|}
\hline $\begin{array}{l}\text { 2. To: (Receiving Organization) } \\
\text { HLW Program }\end{array}$ & $\begin{array}{l}\text { 3. From: Coriginating Organi } \\
\text { Process Engineering }\end{array}$ \\
\hline $\begin{array}{l}\text { 5. Proj./Prog./ } \\
\text { TWRS }\end{array}$ & $\begin{array}{l}\text { 6. Cog. Engr.: } \\
\text { T. W. Crawford H5-49 }\end{array}$ \\
\hline
\end{tabular}

8. Originator Remarks:

Approval/Release

4. Related EDT No.:

NA

7. Purchase Order No.: NA

9. Equip./Component No.: NA

10. System/Bldg./Facility: NA

11. Receiver Renarks:

12. Major Assm. Dwg. No.: NA

13. Permit/Permit Application No.: NA

14. Required Response Date:

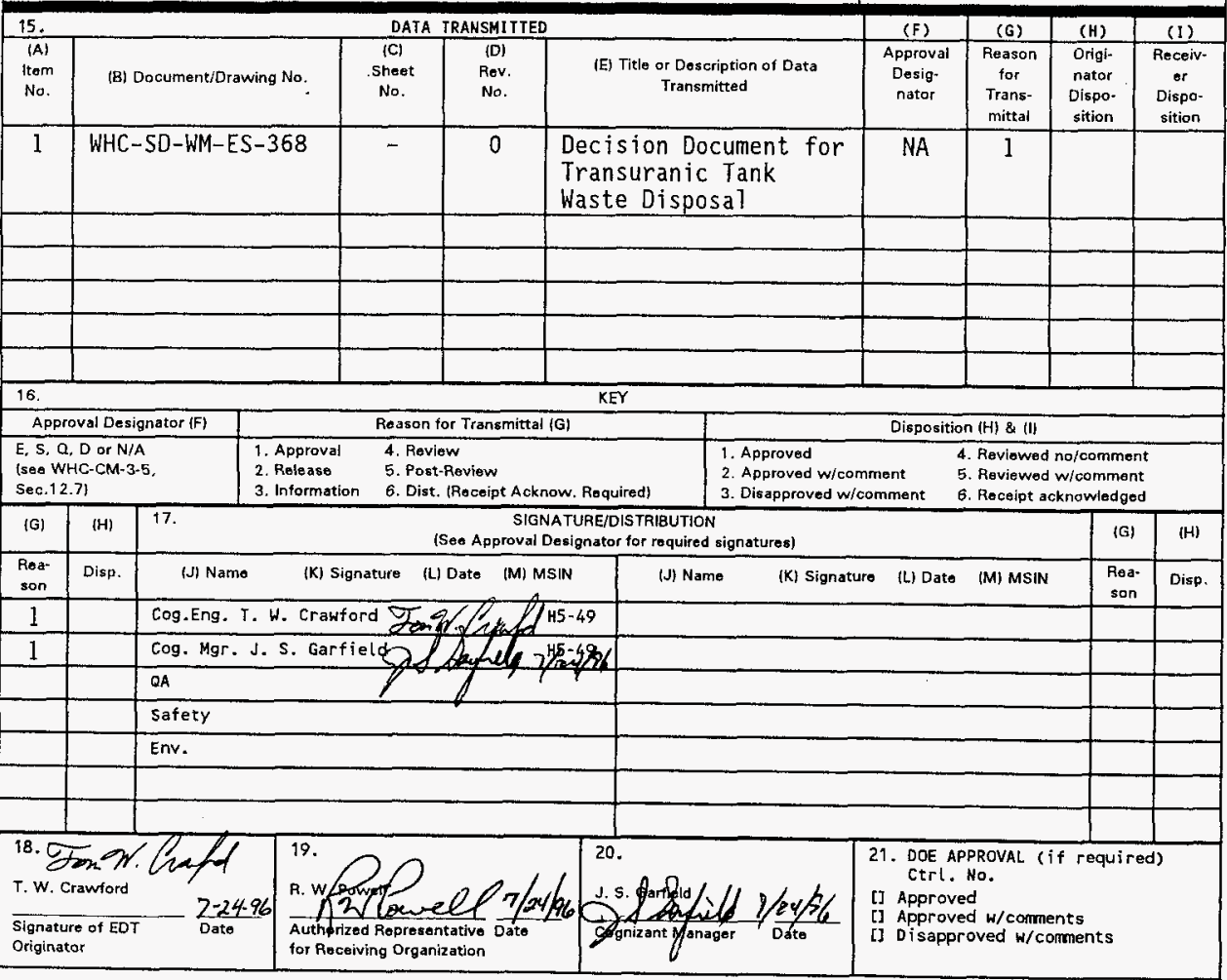

BD-7400-172-2 (04/94) GEF097 


\section{Decision Document for Transuranic Tank Waste Disposal}

T. W. Crawford and C. M. McConville Westinghouse Hanford Company, Richland, WA 99352

U.S. Department of Energy Contract DE-AC06-87RL10930

$\begin{array}{lll}\text { EDT/ECN: } & 608739 & \text { UC: } 721 \\ \text { Org Code: } & 73520 & \text { Charge Code: } \\ \text { B\&R Code: } & \text { EW3130010 } & \text { Total Pages: } 83\end{array}$

Key Words: transuranic, cost benefit

Abstract: During the Tank Waste Remediation System systems requirements review, an issue was raised regarding the disposal of potentially transuranic tank waste. This report documents the decision analysis process to resolve this issue. A decision was made to blend the Hanford Site transuranic tank waste with high-level waste for disposal in an offsite repository. In the interim, the transuranic tank waste will remain stored consistent with the existing safety authorization basis and waste compatibility requirements. The transuranic tank waste will not be sent to the Waste Isolation Pilot Plant for disposal.

The decision is justified based on several decision criteria including cost, volume of waste produced, operability, safety, and technical maturity. There is no cost incentive to segregate transuranic tank waste for disposal at Waste Isolation Pilot Plant. The additional operating and capital costs required to immobilize segregated transuranic tank waste outweigh the savings gained in disposal cost.

TRADEMARK DISCLAIMER. Reference herein to any specific commercial product, process, or service by trade name, trademark, manufacturer, or otherwise, does not necessarily constitute or imply its endorsement, recommendation, or favoring by the United States Government or any agency thereof or its contractors or subcontractors.

Printed in the United states of America. To obtain copies of this document, contact: WhC/BCS Document Control Services, P.O. Box 1970, Mailstop H6-08, Richland WA 99352, Phone (509) 372-2420; Fax (509) 376-4989.
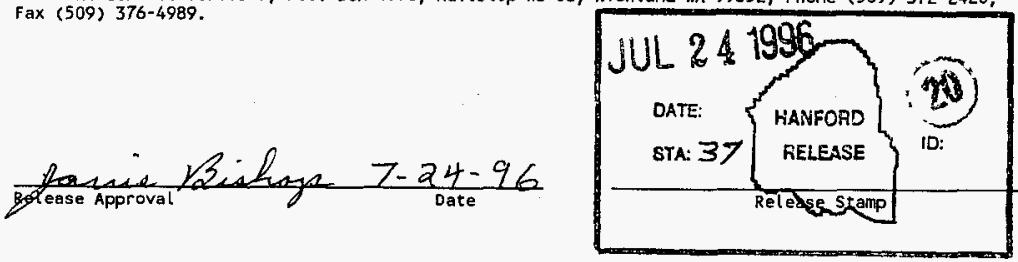

Approved for Public Release 
WHC-SD-WM-ES-368

Revision 0

\section{DECISION DOCUMENT FOR TRANSURANIC TANK WASTE DISPOSAL}

July 1996

T. W. Crawford

C. M. McConville

Westinghouse Hanford Company

Richland, Washington

Prepared for

U.S. Department of Energy

Richland, Washington 
WHC-SD-WM-ES-368

Revision 0

This page intentionally left blank. 
WHC-SD-WM-ES-368

Revision 0

CONTENTS

1.0 INTRODUCTION $: \ldots \ldots \ldots \ldots \ldots \ldots \ldots \ldots \ldots \ldots \ldots \ldots$

2.0 STATEMENT OF THE DECISION $\ldots \ldots \ldots \ldots \ldots \ldots \ldots \ldots \ldots$

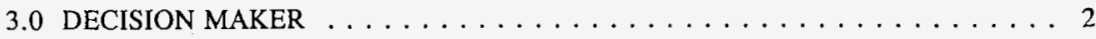

4.0 DECISION ACTION OFFICER $\ldots \ldots \ldots \ldots \ldots \ldots \ldots \ldots \ldots \ldots \ldots$

5.0 ALTERNATIVE SELECTED $\ldots \ldots \ldots \ldots \ldots \ldots \ldots \ldots \ldots$

6.0 DATE OF SELECTION $\ldots \ldots \ldots \ldots \ldots \ldots \ldots \ldots \ldots \ldots \ldots$

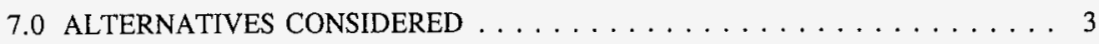

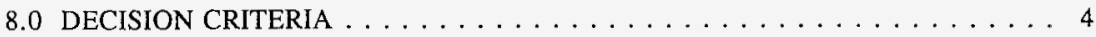

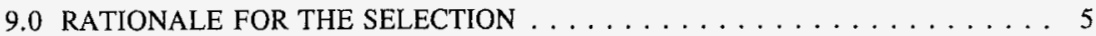

9.1 ANALYSIS OF ALTERNATIVES $\ldots \ldots \ldots \ldots \ldots \ldots \ldots$

9.2 SOURCES OF UNCERTAINTY $\ldots \ldots \ldots \ldots \ldots \ldots \ldots \ldots \ldots \ldots$

9.3 PROGRAMMATIC RISKS AND BENEFITS $\ldots \ldots \ldots \ldots \ldots \ldots 12$

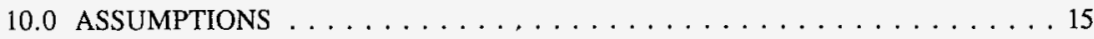

11.0 DECISION ACCEPTANCE $\ldots \ldots \ldots \ldots \ldots \ldots \ldots \ldots \ldots \ldots \ldots$

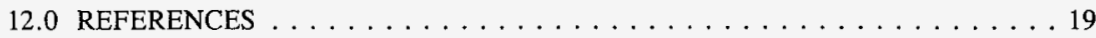

APPENDIXES

A - CASE STUdY EVALUATION $\ldots \ldots \ldots \ldots \ldots \ldots \ldots \ldots$ A-1

B - DETAILED LIFE-CYCLE COST SUMMARY $\ldots \ldots \ldots \ldots \ldots \ldots$ B-1 


\section{WHC-SD-WM-ES-368}

Revision 0

\section{LIST OF FIGURES}

1. Decision Logic for Disposal of Transuranic Tank Waste. . . . . . . . . . . . 1

\section{LIST OF TABLES}

1. Case Study Variables. ... . . . . . . . . . . . . . . . . 4

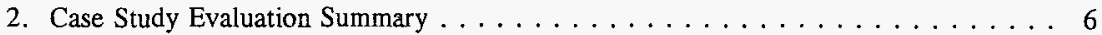

3. Transuranic Waste Segregation Savings and Additions Compared to Blending . . . . 8

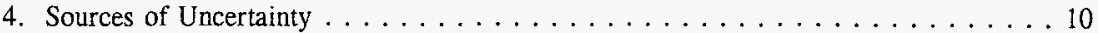

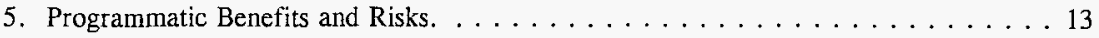


WHC-SD-WM-ES-368

Revision 0

\section{LIST OF TERMS}

DOE

DST

HLW

IRT

LAW

OCRWM

PNNL

RH

RL

SRR

SST

TRU

TWRS

WHC

WIPP
- U.S. Department of Energy

Double-shell tank

High-level waste

Independent Review Team

Low-activity waste

Office of Civilian Radioactive Waste Management

Pacific Northwest National Laboratory

Remote handled

U.S. Department of Energy-Richland Operations Office

Systems requirements review

Single-shell tank

Transuranic

Tank Waste Remediation System

Westinghouse Hanford Company

Waste Isolation Pilot Plant 
WHC-SD-WM-ES-368

Revision 0

This page intentionally left blank. 


\section{DECISION DOCUMENT FOR TRANSURANIC TANK WASTE DISPOSAL}

\subsection{INTRODUCTION}

During the Tank Waste Remediation System (TWRS) systems requirements review (SRR) conducted during November 1994, an issue was raised regarding the disposal of potentially transuranic (TRU) tank waste. Westinghouse Hanford Company (WHC) prepared an action plan that identified a need to resolve this issue, recorded as SRR Finding 2.2.4.5 (Bacon 1996). A decision memorandum addressing SRR Finding 2.2.4.5 as Program Issue \#6 was issued by WHC and approved by the U.S. Department of Energy-Richland Operations Office (RL) (Kinzer 1995). The decision memorandum provided near term program guidance and maintained the potential TRU waste remain segregated from high-level waste (HLW) until disposal options are evaluated (e.g., technical feasibility, cost effectiveness, and regulatory acceptability).

Figure 1 shows the decision logic for disposal of TRU tank waste. Seven single-shell tanks (SSTs) and three double-shell tanks (DSTs) have been identified as potentially containing TRU waste, based on a conservative interpretation of the definitions of HLW and TRU wastes (Colburn 1995). The technical feasibility of immobilizing insoluble TRU tank waste in a HLW vitrification facility has been confirmed (Crawford and Manuel 1996). This report summarizes the TRU waste cost/benefit analysis.

Figure 1. Decision Logic for Disposal of Transuranic Tank Waste.

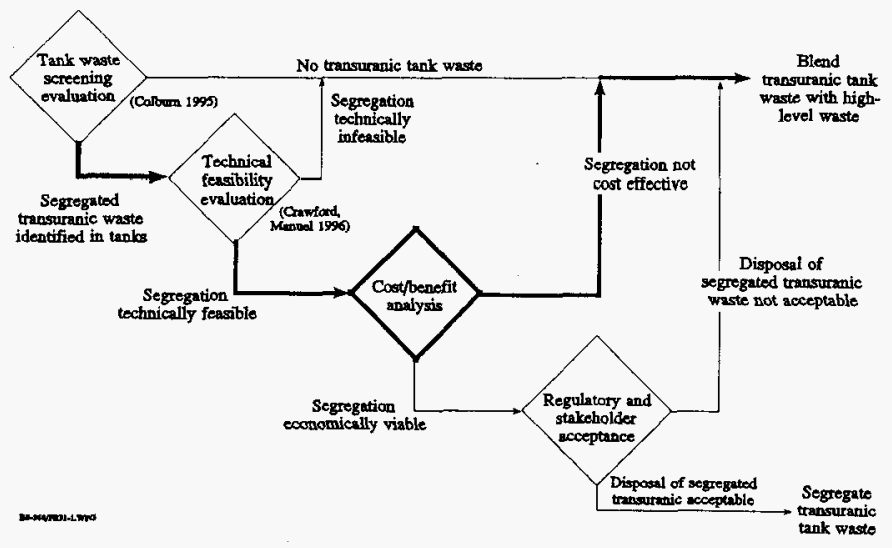


WHC-SD-WM-ES-368

Revision 0

\subsection{STATEMENT OF THE DECISION}

The current TWRS program baseline (WHC 1995) assumes TRU tank waste will be blended with tank HLW, immobilized by vitrification, and disposed of in a geologic repository. Alternatively, it has been proposed that the TRU tank waste remain segregated and be disposed of as remote-handled transuranic (RH-TRU) waste in the WIPP if it is determined to be technically feasible, economically beneficial, and compliant with regulations governing WIPP and TRU wastes. This study evaluates the costs/benefits of these two alternatives to aid the U.S. Department of Energy in determining the disposition of TRU tank wastes.

This decision does not include final resolution of the following U.S. Department of Energy (DOE) policy issues:

1. Formal designation of TRU tank waste

2. WIPP acceptance of TRU tank waste or DOE Office of Civilian Radioactive Waste Management (OCRWM) acceptance of TRU tank waste blended with HLW.

\subsection{DECISION MAKER}

J. O. Honeyman is the responsible decision maker.

\subsection{DECISION ACTION OFFICER}

J. S. Garfield is the decision action officer.

\subsection{ALTERNATIVE SELECTED}

The Hanford Site TRU tank waste will be blended with HLW for treatment and disposal in an offsite geologic repository. In the interim, the TRU tank waste will remain stored consistent with the existing safety authorization basis and waste compatibility requirements. The immobilized TRU tank waste will not be sent to WIPP for disposal. 
WHC-SD-WM-ES-368

Revision 0

\subsection{DATE OF SELECTION}

This decision document satisfies RL milestone T36-96-116, "TRU Waste Disposal Options Cost-Benefit Analysis and Draft Recommendation". The milestone commitment consists of performing a "cost/benefit analysis for TRU waste segregation assessing the impact on retrieval, pretreatment and vitrification plant operation versus the alternative of blending with HLW for repository disposal" (WHC 1995). WHC requests RL concurrence on this decision by August 1, 1996. Concurrence is necessary by this date to incorporate this decision into the tank waste retrieval sequence document, which is a deliverable defined in the Hanford Federal Facility Agreement and Consent Order (referred to as the Tri-Party Agreement) (Ecology et al. 1994) as Milestone M-45-02A, "Initial Single-shell Tank Retrieval Sequence Document," due September 30, 1996.

\subsection{ALTERNATIVES CONSIDERED}

The Hanford Site TRU tank waste is currently segregated from the other tank HLW. Two alternatives exist for disposal of the Hanford Site TRU tank waste:

1. Blend the TRU waste with the tank HLW for disposal in an offsite repository.

2. Maintain TRU tank waste segregation, and dispose of TRU waste at WIPP.

Four case studies were chosen to evaluate the two alternatives. All four case studies are based on conditions assumed by the TWRS Process Flowsheet (Orme 1995), with the exceptions listed in Table 1. All cases assume minimized capital costs and, therefore, no excess processing capacity. Alternative 1 assumes the TRU waste and other tank HLW will be blended prior to immobilization. Case 1 represents Alternative 1 listed above and matches the TWRS Process Flowsheet (Orme 1995) conditions (i.e., uniform blending of all 177 tanks and Hanford Waste Vitrification Plant (HWVP) glass oxide limits in addition to a $10 \mathrm{MT} /$ day vitrification capacity). 
WHC-SD-WM-ES-368

Revision 0

Table 1. Case Study Variables.

\begin{tabular}{|l|c|c|c|c|}
\hline Case study variables & $\begin{array}{c}\text { Case 1, } \\
\text { TWRS Process } \\
\text { Flowsheet, (Ome } \\
1995)\end{array}$ & $\begin{array}{c}\text { Case 2a, Segregated } \\
\text { TRU waste }\end{array}$ & $\begin{array}{c}\text { Case 2b, } \\
\text { Segregated TRU } \\
\text { waste, crystalline } \\
\text { TRU waste form }\end{array}$ & $\begin{array}{c}\text { Case 2c, } \\
\text { Segregated TRU } \\
\text { waste, 10.7 MT/day } \\
\text { melter }\end{array}$ \\
\hline $\begin{array}{l}\text { High-Level and TRU } \\
\text { waste blending }\end{array}$ & Blend & Segregate & Segregate & Segregate \\
\hline Melter size & $10 \mathrm{MT} / \mathrm{day}$ & $10 \mathrm{MT} /$ day & $10 \mathrm{MT} / \mathrm{day}$ & $10.7 \mathrm{MT} / \mathrm{day}$ \\
\hline TRU waste form & $\begin{array}{c}\text { Non-crystalline } \\
\text { glass }\end{array}$ & $\begin{array}{c}\text { Non-crystalline } \\
\text { glass }\end{array}$ & Crystalline & Non-crystalline glass \\
\hline
\end{tabular}

TRU $=$ Transuranic

TWRS $=$ Tank Waste Remediation System.

Alternative 2 assumes TRU waste segregation will be maintained during the pretreatment and immobilization processes. Cases $2 a, 2 b$, and $2 c$ are variations of Alternative 2 and segregate the TRU tank waste from the HLW. The segregated TRU waste inventory is comprised of approximately $7,600 \mathrm{~m}^{3}$ sludge contained in seven SSTs: 241 -T201, 241-T-202, 241-T-203, 241-T-204, 241-T-110, 241-T-111, 241-T-112, and three DSTs: 241-SY-102, 241-AW-103, 241-AW-105 (Colburn 1995). The segregated TRU tank waste represents approximately 3 percent of the total liquid and sludge/solids inventory in the 177 SSTs and DSTs. Case 2a matches the TWRS Process Flowsheet (Orme 1995) with the exception of segregating the TRU tank waste from the HLW. Case $2 b$ assumes the same conditions as Case $2 a$ with the exception of waste oxide limits for a crystalline, nonhomogeneous, TRU waste form. Case $2 \mathrm{c}$ assumes the same conditions as Case $2 \mathrm{a}$ but with increased vitrification and canister handling capacity to match the operating duration of Case 1.

Since WIPP does not require glass as a waste form, alternative waste forms were considered including grout and polyethylene (Boomer et al. 1993). It is estimated these alternative waste forms would produce from two to five times more waste volume than borosilicate glass. In addition to increased volume, a separate facility with adequate radiation shielding would need to be constructed for the alternative immobilization process. A new facility would increase the capital cost of treating segregated TRU tank waste. A facility is already pianned to produce HLW glass. Construction of a new facility to produce an alternative waste form for segregated TRU waste would not be economically justified. Therefore, TRU waste forms other than glass or glass-like material were excluded from further consideration in this analysis.

\subsection{DECISION CRITERIA}


WHC-SD-WM-ES-368

Revision 0

The four cases are evaluated based on the following decision criteria:

1. Life-cycle cost (including disposal costs)

2. Life-cycle cost (excluding disposal costs)

3. Process duration (years)

4. Volume of immobilized HLW produced

5. Volume of immobilized TRU waste produced

6. Volume and radioactivity of immobilized low-activity waste (LAW) left onsite

7. Operability (a measure of the difficulties encountered while conducting treatment facility operations)

8. Safety

9. Technical Maturity (a measure of the development required to implement the technologies necessary to accomplish each alternative).

The first six decision criteria ( 1 through 6 ) are based on the values of governments and constituencies with a stake in the future of the Hanford Site (PNNL 1996). The last three decision criteria (7 through 9) are selected specifically to facilitate the TRU waste segregation decision analysis. The decision criteria 7 through 9 reflect concerns designers and facility operators would have with regard to selecting technologies and processes to treat the TRU wastes.

\subsection{RATIONALE FOR THE SELECTION}

Blending TRU tank waste with HLW for disposal in an offsite repository is justified based on several decision criteria including cost, volume of waste produced, operability, safety, and technical maturity. An evaluation summary shown in Table 2 indicates there is no cost incentive to segregate TRU tank waste for disposal at WIPP. A summary of the significant differences among the cases (Table 3) shows the operating cost and capital cost of producing segregated TRU waste outweigh the potential savings gained in disposal cost.

In general, blending of TRU waste with HLW produces less waste volume and fewer canisters of glass. Fewer canisters decrease the safety risk during transportation to offsite repositories. Blending of the two waste types would also decrease the operations complexity for retrieval, pretreatment, and immobilization. Blending of TRU and HLW tank waste could use mature technologies. The only situation where a minor cost savings could be found (Case $2 b$ ), requires technology development to produce a crystalline form which would offset at least a portion of the potential savings. Several sources of uncertainty and programmatic risks also support the decision as shown in Sections 9.2 and 9.3. 


\section{WHC-SD-WM-ES-368 Revision 0}

Table 2. Case Study Evaluation Summary. (2 sheets)

\begin{tabular}{|c|c|c|c|c|}
\hline \multirow[b]{2}{*}{ Decision criteria } & $\begin{array}{c}\text { Blended HLW and } \\
\text { TRU Waste }\end{array}$ & \multicolumn{3}{|c|}{ Segregated TRU Waste } \\
\hline & $\begin{array}{l}\text { Case 1, TWRs } \\
\text { Process Plowsheet } \\
\text { (Orme 1995) }\end{array}$ & $\begin{array}{l}\text { Case 2a, TWRS } \\
\text { Process Flowsheet } \\
\text { (Orme 1995) } \\
\text { Conditions }\end{array}$ & $\begin{array}{l}\text { Case } 2 b \text {, Crystalline } \\
\text { TRU waste form }\end{array}$ & $\begin{array}{c}\text { Case } 2 \mathrm{c}, \\
10.7 \mathrm{MT} / \text { day melter }\end{array}$ \\
\hline \multicolumn{5}{|c|}{ Cost (Millions of 1995 dollars) } \\
\hline Labor ${ }^{2}$ & 790 & 932 & 829 & 870 \\
\hline Consumables $^{a}$ & 365 & 389 & 363 & 389 \\
\hline Canisters $^{2}$ & 71 & 79 & 73 & 79 \\
\hline DST retrieval operations & 864 & 1,008 & 912 & 864 \\
\hline Startup training & 180 & 180 & 180 & 198 \\
\hline $\begin{array}{l}\text { Decontamination and } \\
\text { decommissioning }\end{array}$ & 742 & 743 & 743 & 791 \\
\hline Hot 10 ondocost & 1012 & 3,31 & 3100 & 300 \\
\hline Facility capital cost ${ }^{2}$ & 1,873 & 1,875 & 1,875 & 1,975 \\
\hline Replacement melters ${ }^{*}$ & 195 & 234 & 195 & 195 \\
\hline Interim storage & 636 & 530 & 530 & 530 \\
\hline $106 / 8$ apial costos & 270 & \% 12640 & 2600 & 2709 \\
\hline 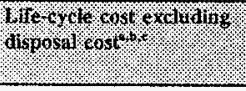 & 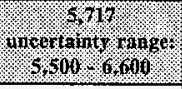 & ancongur range & 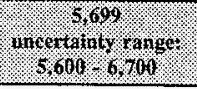 & 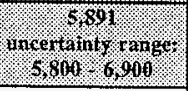 \\
\hline Repository disposal cost & 2.788 & 2,565 & 2,565 & 2,565 \\
\hline WIPP disposal cost & N/A & 55 & 28 & 55 \\
\hline $10410000 \% 00 \%$ & 2786 & 2620 & 2693 & 2620 \\
\hline 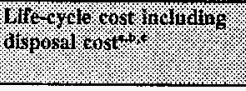 & 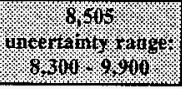 & 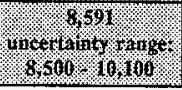 & 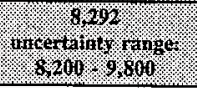 & 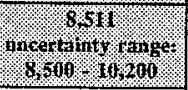 \\
\hline \multicolumn{5}{|c|}{ Immobilized Waste Volume } \\
\hline HLW $\left(\mathrm{m}^{3}\right)^{\mathrm{a}}$ & 8,970 & 8,250 & 8,250 & 8.250 \\
\hline TRU waste $\left(\mathrm{m}^{3}\right)^{\mathrm{a}}$ & 0 & 1,310 & 660 & 1,310 \\
\hline $\mathrm{TRU}+\mathrm{HLW}\left(\mathrm{m}^{3}\right)^{\mathrm{a}}$ & 8,970 & 9,560 & 8,910 & 9,560 \\
\hline HLW canisters $\left(1.26 \mathrm{~m}^{3}\right)^{\mathrm{a}, \mathrm{d}}$ & 7,120 & 6,550 & 6.550 & 6,550 \\
\hline $\begin{array}{l}\text { TRU waste canisters } \\
\left(0.71 \mathrm{~m}^{3}\right)^{a_{0}}\end{array}$ & 0 & 1,850 & 925 & 1.850 \\
\hline TRU + HLW canisters ${ }^{\mathbf{2}, \mathbf{d . 0}}$ & 7,120 & 8,400 & 7,475 & 8,400 \\
\hline Low-activity waste $\left(\mathrm{m}^{3}\right)$ & \multicolumn{4}{|c|}{ Same for all cases, not a discriminator. } \\
\hline
\end{tabular}


WHC-SD-WM-ES-368

Revision 0

Table 2. Case Study Evaluation Summary. (2 sheets)

\begin{tabular}{|c|c|c|c|c|}
\hline \multirow[b]{2}{*}{ Decision criteria } & Blended HLW and & \multicolumn{3}{|c|}{ Segregated TRU Waste } \\
\hline & $\begin{array}{l}\text { Case 1. TWRS } \\
\text { Process Flowsheet } \\
\text { (Onme 1995) }\end{array}$ & $\begin{array}{l}\text { Case 2a, TWRs } \\
\text { Process Flowsheet } \\
\text { (Orme 1995) } \\
\text { Conditions }\end{array}$ & $\begin{array}{l}\text { Case } 2 b, \text { Crystalline } \\
\text { TRU waste form }\end{array}$ & $\begin{array}{l}\text { Case } 2 \mathrm{c}, \\
10.7 \mathrm{MT} / \text { day melter }\end{array}$ \\
\hline \multicolumn{5}{|c|}{ Process Duration } \\
\hline Process duration (years) ${ }^{a, b}$ & $\begin{array}{l}13 \\
\text { uncertainty range: } \\
11.5-18\end{array}$ & $\begin{array}{l}16 \\
\text { uncertainty range: } \\
14.5-21\end{array}$ & $\begin{array}{l}14 \\
\text { uncertainty range: } \\
13-19\end{array}$ & $\begin{array}{l}13 \\
\text { uncertainty range: } \\
12-18\end{array}$ \\
\hline \multirow[t]{2}{*}{$\begin{array}{l}\text { Tri-Patty Agreement schedule } \\
\text { impacts }\end{array}$} & $\begin{array}{l}\text { Allows deferral of } \\
\text { HLW processing } \\
\text { for early SST } \\
\text { closure }^{\text {h }}\end{array}$ & \multicolumn{3}{|c|}{$\begin{array}{l}\text { WIPP closure drives HLW processing to compete with SST closure } \\
\text { and precludes sequential processing alternatives for LAW and } \\
\text { HLW. }\end{array}$} \\
\hline & $\begin{array}{c}90 \text { percent } \\
\text { probability of } \\
\text { meeting Tri-Party } \\
\text { Agreement } \\
\text { completion date }\end{array}$ & $\begin{array}{c}75 \text { percent } \\
\text { probability of } \\
\text { meeting Tri-Party } \\
\text { Agreement } \\
\text { completion dateg }\end{array}$ & $\begin{array}{l}80 \text { percent probability of } \\
\text { meeting Tri-Party } \\
\text { Agreement completion } \\
\text { date }\end{array}$ & $\begin{array}{c}90 \text { percent } \\
\text { probability of } \\
\text { meeting Tri-Party } \\
\text { Agreement } \\
\text { completion date }\end{array}$ \\
\hline \multicolumn{5}{|c|}{ Other Decision Criteria } \\
\hline Operability & & \multicolumn{3}{|c|}{$\begin{array}{l}\text { Segregating the TRU waste from the HLW would increase } \\
\text { operations complexity for retrieval, pretreatment, and vitrification. }\end{array}$} \\
\hline Safety & & \multicolumn{3}{|c|}{$\begin{array}{l}\text { Increased safety risks due to increased number of canisters and } \\
\text { offsite shipments. }\end{array}$} \\
\hline Technical maturity & $\begin{array}{l}\text { Uses proven } \\
\text { technology }\end{array}$ & $\begin{array}{l}\text { Uses proven } \\
\text { technology }\end{array}$ & $\begin{array}{l}\text { Requires melter and } \\
\text { glass form development } \\
\text { which is not included in } \\
\text { the life-cycle cost } \\
\text { estirnate. }\end{array}$ & $\begin{array}{l}\text { Uses proven } \\
\text { technology }\end{array}$ \\
\hline
\end{tabular}

HLW $=$ High-level waste

RH $=$ Remote handled

SST $=$ Single-shell tank

TRU = Transuranic

WIPP $=$ Waste Isolation Pilot Plant

"Single values reported for cost, volume, and duration represent "base case" values calculated by the INSIGHT

Model. Algorithms and references for each input value are reported in Crawford and McConville 1996, Appendix A. Due to rounding, totals may not equal sum of numbers shown.

"Uncertainty ranges reported for life-cycle cost and duration represent cumulative probabilities of 20 percent and 80 percent (Crawford and McConville 1996, Appendix A).

"Cost values represent HLW and TRU waste processing only. The total life-cycle cost does not include SST

retrieval, pretreatment, or low-activity waste processing.

'HLW canister being evaluated for acceptance by DOE-OCRWM.

"RH-TRU waste canister currently accepted by DOE-WTPP.

'TRU tank waste must be immobilized by 2021 to meet the RH-TRU waste emplacement window at WIPP.

'Assuming the HLW/TRU waste process begins in 2009, the process duration must be 19 years or less to meet the

Tri-Party Agreement mandated HLW/TRU waste immobilization completion date of 2028 (Milestone M-51-00).

"SST closure to be completed by September 2024 (Tri-Party Agreement Milestone M-45-00). 
Table 3. Transuranic Waste Segregation Savings and Additions Compared to Blending. Reference Case: TWRS Process Flowsheet (Orme 1995) Case 1

\begin{tabular}{|c|c|c|c|c|c|c|}
\hline & \multicolumn{2}{|c|}{$\begin{array}{c}\text { Case 2a, TWRS Process } \\
\text { Flowsheet (Orme 1995) } \\
\text { Conditions }\end{array}$} & \multicolumn{2}{|c|}{$\begin{array}{l}\text { Case } 2 b \text {, Crystalline } \\
\text { TRU waste form }\end{array}$} & \multicolumn{2}{|c|}{$\begin{array}{c}\text { Case } 2 \mathrm{c}, 10.7 \mathrm{MT} / \text { day } \\
\text { melter }\end{array}$} \\
\hline & Savings & Additions & Savings & Additions & savings & additions \\
\hline \multicolumn{7}{|c|}{ Cost (Millions of 1995 dollars) } \\
\hline Labor & & 1.142 & & +39 & & +80 \\
\hline Consumables & & +24 & -2 & & & +24 \\
\hline Canisters & & +8 & & +2 & & +8 \\
\hline DST retrieval operations & & $1 \times 44$ & & +48 & & 0 \\
\hline Startup training & 0 & 0 & 0 & 0 & & +18 \\
\hline $\begin{array}{l}\text { Decontamination and } \\
\text { decommissioning }\end{array}$ & & +1 & & +1 & & +49 \\
\hline Total expense cost & & +319 & & +88 & & +178 \\
\hline Facility capital cost & & +2 & & +2 & & 1.102 \\
\hline Replacement melters & & +39 & 0 & 0 & 0 & 0 \\
\hline Interim storage & 106 & & 108 & & 106 & \\
\hline Total capital cost & -65 & & -105 & & -5 & \\
\hline $\begin{array}{l}\text { Life-cycle cost excluding } \\
\text { disposal cost }\end{array}$ & & +253 & -18 & & & +174 \\
\hline Repository disposal cost & 2233 & & 223 & & 223 & \\
\hline WIPP disposal cost & & +55 & & +28 & & +55 \\
\hline Total disposal cost & -168 & & -195 & & -168 & \\
\hline $\begin{array}{l}\text { Life-cycle cost including } \\
\text { disposal cost }\end{array}$ & & +86 & -213 & & & +7 \\
\hline \multicolumn{7}{|c|}{ Immobilized Waste Volume } \\
\hline$T R U+H L W\left(m^{3}\right)$ & & 1590 & -60 & & & $2.5 \%$ \\
\hline $\begin{array}{l}\text { TRU + HLW } \\
\text { canisters } \\
\end{array}$ & & 1,280 & & +355 & & 4,280 \\
\hline Low-activity waste $\left(\mathbf{m}^{3}\right)$ & 0 & 0 & 0 & 0 & 0 & 0 \\
\hline \multicolumn{7}{|c|}{ Process Duration } \\
\hline $\begin{array}{l}\text { Process duration } \\
\text { (years) }\end{array}$ & & +3 & & +1 & 0 & 0 \\
\hline
\end{tabular}

DST $=$ Double-shell tank

HLW $=$ High-level waste

TRU $=$ Transuranic

TWRS = Tank Waste Remediation System

Note: The values shown were determined by subtracting the Case 1 values in Table 2 from the Case 2 values in Table 2. The shaded values identify significant savings or additions. 


\subsection{ANALYSIS OF ALTERNATIVES}

The INSIGHT Model is used with a decision analysis software, Supertree ${ }^{1}$ (McConville and Johnson 1995), to perform deterministic and probabilistic evaluations for the first five decision criteria listed in Section 8.0: (1) total life-cycle cost, (2) life-cycle cost excluding disposal costs, (3) process duration, (4) volume of immobilized HLW produced, and (5) volume of immobilized TRU waste produced. Appendix A describes the input variables and algorithms constructed to calculate values for each of these five decision criteria. The sixth criterion, volume of immobilized LAW produced, is determined to be the same for all cases and is not included in the deterministic and probabilistic evaluations. The last three decision criteria (operability, safety, technical maturity) are evaluated qualitatively. Table 2 summarizes the case study evaluation results for each of the decision criteria. Table 3 summarizes the cost, volume, and duration differences among the cases. The details of the deterministic and probabilistic evaluations are provided in Appendix A.

The INSIGHT Model, coupled with decision analysis software, evaluates the decision criteria in two steps: (1) deterministic sensitivity analysis, and (2) probabilistic analysis. More than 100 variables are assessed in each sensitivity analysis, with each variable input as a range of high, mid, and low values. (The applicable variables for this study are defined in Section A3.0 of Appendix A). The deterministic sensitivity analysis identifies which input variables have the most significant effect on the decision criterion being evaluated (e.g., lifecycle cost, HLW volume, process duration). These significant variables provide the frame for the subsequent probabilistic analysis. Probabilities of 25 percent, 50 percent, and 25 percent are assigned to the high, mid, and low values of the top five significantvariables identified in each sensitivity analysis. The decision criterion is calculated for all possible combinations of the framing variables based on their ranges and assigned probabilities. The result is a cumulative probability distribution over the full range of the decision criterion.

The point values reported in Table 2 for cost, volume, and duration were determined by the INSIGHT Model with all input variables set to their "base case" value (e.g., midrange value). The range of life-cycle cost and process duration values reported in Table 2 were determined from cumulative probability distribution charts, with the low value representing a 20 percent probability and the high value representing an 80 percent probability (see Appendix A, Section A5.0). Table 3 subtracts the Case 1 values in Table 2 from the Case 2 values in Table 2 to show the savings (-) and additions (+) required to segregate the TRU tank waste.

Segregation of TRU waste increases the total non-crystalline glass volume produced by approximately $600 \mathrm{~m}^{3}$ as shown by Cases $2 \mathrm{a}$ and $2 \mathrm{c}$. The segregated TRU waste has a high zirconium concentration and the immobilized TRU waste volume is therefore sensitive to the achievable zirconium oxide concentration in non-crystalline glass. Case $2 \mathrm{~b}$ produces a

${ }^{1}$ Supertree is a registered trademark of Strategic Decisions Group. 
crystalline TRU waste form with a higher zirconium oxide concentration limit that reduces the immobilized TRU waste volume.

Variations in life-cycle cost including disposal cost among the four case studies are negligible. In addition, variations in life-cycle cost excluding life-cycle cost are very small and well within the range of uncertainty. Comparison of the evaluation results for the two decision criteria (i.e., life-cycle cost including disposal cost and life-cycle cost excluding disposal cost) shows that uncertainties associated with disposal costs cause the variations among the cases to become less distinctive. Although Case $2 \mathrm{~b}$ shows a potential of saving a few hundred million dollars, the incremental cost of developing, constructing, and operating a steep-sloped bottom-pour melter required to produce the crystalline waste form is not included in the estimate and would be expected to offset a portion of the potential savings. See Appendix B for a more detailed life-cycle cost summary.

Cases 1 and $2 c$ have the greatest probability of meeting the Tri-Party Agreement completion date for HLW/TRU waste immobilization. Assuming the HLW/TRU waste process begins in 2009 , the process duration must be 19 years or less to meet the Tri-Party Agreement mandated completion date of 2028 . The cumulative probability of meeting the completion date is approximately 90 percent for Cases 1 and $2 \mathrm{c}, 80$ percent for Case $2 \mathrm{~b}$, and 75 percent for Case $2 \mathrm{a}$.

\subsection{SOURCES OF UNCERTAINTY}

There are seven major sources of uncertainty that impact cost, volume, and duration: (1) tank waste inventory, (2) heel remaining in tanks, (3) blending factor, (4) pretreatment efficiencies, (5) oxide limits in immobilized waste form, (6) regulatory acceptance, and (7) complexity of interfaces. Table 4 summarizes the uncertainties favoring blending the TRU waste with HLW or segregating TRU waste.

Table 4. Sources of Uncertainty.

\begin{tabular}{|l|c|c|}
\hline \multicolumn{1}{|c|}{ Uncertainties } & $\begin{array}{c}\text { Favors blending transuranic } \\
\text { waste with high-level waste }\end{array}$ & $\begin{array}{c}\text { Favors segregation of } \\
\text { transuranic waste }\end{array}$ \\
\hline 1. Tank waste inventory & $\mathrm{X}$ & \\
\hline 2. Heel remaining in tanks & $\mathrm{X}$ & \\
\hline 3. Blending factor & & $\mathrm{X}$ \\
\hline 4. Pretreatment efficiencies & $\mathrm{X}$ & \\
\hline 5. Oxide limits in immobilized waste form & $\mathrm{X}$ & \\
\hline 6. Regulatory acceptance & $\mathrm{X}$ & \\
\hline 7. Complexity of interfaces & $\mathrm{X}$ & \\
\hline
\end{tabular}


WHC-SD-WM-ES-368

Revision 0

1. Tank Waste Inventory. An important uncertainty factor in making this decision is the proposed revision in the Hanford Site tank composition inventories. (Draft $\mathrm{C}$ of the Best-Basis Inventories of Chemicals and Radionuclides in Hanford Site Tank Waste [Kupfer et al., 1996] documents the "Best-Basis" inventories to date). The provisional "Best-Basis" inventories substantially changes the estimated inventories for several key components that affect waste loading in a HLW glass. For the provisional "Best-Basis" inventory, the chromium inventory increases by more than a factor of two making it the probable limiting glass component. Waste in the TRU tanks collectively have a low concentration of chromium. Due to the low chromium concentration, segregating TRU tank waste from HLW may not decrease the volume of HLW. The net result would be the same cost for immobilization and disposal of HLW plus the additional cost of immobilization and disposal of segregated TRU waste.

2. Heel Remaining in Tanks. The TWRS Process Flowsheet (Orme 1995) assumes that 100 percent of the waste in the tanks would be retrieved. Given the refractory nature of some of material in the tank, it is not clear that this will be achieved. If it is not, then the calculated amount of HLW and TRU waste will be overestimated. The INSIGHT model takes this uncertainty into account by using ranges of retrieval efficiencies for both SSTs and DSTs. Decreased retrieval efficiency lowers the volumes of HLW and TRU waste produced. A smaller HLW volume increases the impact of TRU tank waste processing, thereby making segregation of TRU tank waste less attractive.

3. Blending Factor. The INSIGHT Model cost, volume, and duration calculations assume that all tank waste is perfectly blended. In practice, it is unlikely that perfect blending of the insoluble HLW would be achieved. A blending factor of 1.2 applied to HLW only, is suggested as a reasonable upper bound by an independent review team which was assembled by DOE to estimate a range of HLW glass volume for the TWRS EIS (Taylor and Lang 1996). A blending factor is not required for the segregated TRU waste. Blending the TRU waste is not perceived as a problem since the TRU waste volume is small (approximately $7,600 \mathrm{~m}^{3}$ ). A blending factor of 1.2 applied to HLW would increase the HLW glass volume, processing duration, operating cost, and disposal cost by about 20 percent. In general, increasing the volume of HLW decreases the impact of processing segregated TRU tank waste, thereby making segregation of TRU tank waste more attractive.

4. Pretreatment Efficiencies. Pretreatment of tank sludge will be performed to remove selected materials and reduce the volume of product HLW glass. The TWRS Process Flowsheet (Orme 1995) is based on a water wash to remove soluble species, followed by caustic leaching of the insoluble species. The separation efficiencies assumed in the flowsheet reflect the best judgement based on available experimental work. However, all tank waste groups have not been 
WHC-SD-WM-ES-368

Revision 0

sampled and analyzed. Thus, the pretreatment efficiencies constitute a potentially significant source of uncertainty. Uncertainty in separation efficiencies have been incorporated into the probabilistic assessment of the HLW and TRU waste volume.

5. Oxide Limits in Immobilized Waste Form. The TWRS Process Flowsheet (Orme 1995) assumes a set of waste oxide loading limits based on the HWVP glass composition. Two factors have changed since the design of HWVP that add uncertainty to these waste oxide limits and their impact on the volume of HLW. The two factors are the inclusion of SSTs in the feed inventory and advances in glass formulations. The INSIGHT model takes the oxide limit uncertainty into account by using ranges of limits for each critical oxide component. For the limiting waste oxide component, sodium, an increased waste oxide limit from $12.5 \mathrm{wt} \%$ to $20 \mathrm{wt} \%$ decreases the volume of HLW produced by 1,300 to $1,600 \mathrm{~m}^{3}$. A smaller $\mathrm{HLW}$ volume increases the impact of TRU tank waste processing, thereby making segregation of TRU tank waste less attractive.

6. Regulatory Acceptance. Acceptability of a unique waste form (i.e., Hanford TRU tank waste) by WIPP and the state of New Mexico is uncertain. In addition, it is uncertain whether WIPP could receive RH-TRU tank waste and remain within the legal waste volume limit. WIPP has the capacity to accept a total RH-TRU waste volume of $7,080 \mathrm{~m}^{3}$, according to the Agreement for Consultation and Cooperation Between the Department of Energy and the State of New Mexico on the Waste Isolation Pilot Plant (DOE and the State of New Mexico 1981). Other DOE sites have estimated a total inventory of approximately $5,000 \mathrm{~m}^{3}$ for shipment to WIPP (DOE 1995). The Hanford Site has estimated an inventory of approximately $3,000 \mathrm{~m}^{3}$, excluding TRU tank waste (Kosiancic 1996). The total projected inventories from the Hanford Site and other DOE sites exceed WIPP's legally mandated capacity.

7. Complexity of Interfaces. Blending the TRU waste with HLW would require interfacing with only one repository. Segregating the TRU tank waste for disposal at WIPP would require interfacing with two separate repositories for certification and disposal of tank waste. The additional repository interface would increase the complexity of meeting applicable customer requirements, transportation arrangements, documentation, etc.

\subsection{PROGRAMMATIC RISKS AND BENEFITS}

The major programmatic benefits and risks associated with the two TRU waste disposal alternatives are summarized in Table 5 . 


\section{WHC-SD-WM-ES-368}

Revision 0

Table 5. Programmatic Benefits and Risks.

\begin{tabular}{|c|c|c|}
\hline & Benefit & Risk \\
\hline \multirow[t]{2}{*}{$\begin{array}{l}\text { Blending } \\
\text { TRU waste } \\
\text { with HLW }\end{array}$} & $\begin{array}{l}\text { Less total volume of } \\
\text { immobilized waste. Blending } \\
\text { the TRU waste with HLW for } \\
\text { disposal results in a smaller total } \\
\text { volume than segregating the two } \\
\text { waste types. }\end{array}$ & \multirow[t]{2}{*}{$\begin{array}{l}\text { DOE Order Interpretation. There is a risk that a DOE interpretation } \\
\text { of DOE Order } 5820.2 \text { a would not allow mixing of TRU tank waste } \\
\text { with HLW for disposition at the geologic repository. A strict } \\
\text { interpretation could require TRU waste to be stored and treated as a } \\
\text { segregated waste stream and disposed of at WIPP. This risk is small } \\
\text { since a precedent has been set at Savannah River Site for blending } \\
\text { these waste types in underground storage tanks. }\end{array}$} \\
\hline & $\begin{array}{l}\text { Less Complexity. Blending the } \\
\text { TRU waste with HLW for } \\
\text { disposal is simpler than } \\
\text { segregating and sending to } \\
\text { separate disposal facilities. }\end{array}$ & \\
\hline \multirow[t]{4}{*}{$\begin{array}{l}\text { Segregating } \\
\text { TRU waste }\end{array}$} & \multirow{4}{*}{$\begin{array}{l}\text { Less Waste Stored Onsite if } \\
\text { WIPP Opens and Geologic } \\
\text { Repository Does Not Open. If } \\
\text { WIPP opens and accepts } \\
\text { Hanford's immobilized TRU } \\
\text { tank waste, and if the federal } \\
\text { geologic repository is delayed or } \\
\text { does not open, about } 720 \mathrm{~m}^{3} \\
\text { (approxirnately } 8 \text { percent) less } \\
\text { waste would be stored onsite. } \\
\text { However, the TRU tank waste } \\
\text { to be sent to WTPP contains less } \\
\text { than one percent of the total } \\
\text { curies from TRU radionuclides } \\
\text { in the tank waste. }\end{array}$} & $\begin{array}{l}\text { WIPP May Not Have Sufficient Capacity for RH-TRU waste. It is } \\
\text { uncertain whether WIPP could receive RH-TRU tank waste and } \\
\text { remain within the legal waste volume limit. WIPP has the capacity to } \\
\text { accept a total RH-TRU waste volume of } 7,080 \mathrm{~m}^{3} \text {, according to the } \\
\text { Agreement for Consultation and Cooperation Between the Department } \\
\text { of Energy and the State of New Mexico on the Waste Isolation Pilot } \\
\text { Plant (DOE and the State of New Mexico 1981). Other DOE sites } \\
\text { have estimated a total inventory of approximately } 5,000 \mathrm{~m}^{3} \text { for } \\
\text { shipment to WIPP (DOE } 1995 \text { ). The Hanford Site has estimated an } \\
\text { inventory of approximately } 3,000 \mathrm{~m}^{3} \text {, excluding TRU tank waste } \\
\text { (Kosiancic 1996). The total projected inventories from the Hanford } \\
\text { Site and other DOE sites exceed WIPP's capacity. }\end{array}$ \\
\hline & & $\begin{array}{l}\text { Increased Cost If WIPP Does Not Open Or Rejects RH-TRU Tank } \\
\text { Waste. If segregated TRU waste is immobilized, and if WIPP does } \\
\text { not open or cannot accept Hanford TRU tank waste, then: (a) another } \\
\text { interim storage facility would be required at a capital cost of about } \\
\$ 100 \text { million, (b) annul interim storage operating costs would } \\
\text { increase by about } 20 \text { percent, and (c) disposal costs at the geologic } \\
\text { repository would increase by an additional } \$ 500 \text { miltion. }\end{array}$ \\
\hline & & $\begin{array}{l}\text { Schedule Slippage. Completion of retrieval and immobilization of } \\
\text { TRU tank waste within the WIPP waste emplacement window may not } \\
\text { occur due to schedule interferences. This study assumes there is no } \\
\text { impact on vitrification operations to immobilize TRU waste by } 2021 \\
\text { to meet the RH-TRU waste emplacement window at WIPP. Also } \\
\text { assumed is that there is no impact on retrieval to retrieve } 10 \text { TRU } \\
\text { tanks before } 2019 \text {. }\end{array}$ \\
\hline & & $\begin{array}{l}\text { Increased Retrieval Complexity. Retrieval complexity may increase to } \\
\text { maintain a segregated TRU waste stream. The TRU waste cannot be } \\
\text { commingled with HLW and still retain TRU classification. Retrieval } \\
\text { and transfer of TRU waste tanks may need to occur first in the } \\
\text { schedule to prevent cross contamination with HLW. }\end{array}$ \\
\hline DOE & U.S. Department of Energ & \\
\hline HLW & High-level waste & \\
\hline RH & Remote handled & \\
\hline $\begin{array}{l}\text { TRU } \\
\text { WTPP }\end{array}$ & Transuranic & \\
\hline
\end{tabular}


WHC-SD-WM-ES-368

Revision 0

This page intentionally left blank. 
WHC-SD-WM-ES-368

Revision 0

\subsection{ASSUMPTIONS}

The key assumptions related to the disposal of TRU tank waste are discussed below:

Meeting RH-TRU Waste Criteria. It is assumed that vitrified tank waste would meet WIPP's waste acceptance criteria with respect to waste form and other criteria. The TRU waste does meet the criteria of being greater than $100 \mathrm{nCi}$ per gram of transuranic radionuclides. Also, it meets the radiation dose rate criteria to be remote handled waste instead of contact handled waste (Crawford and Manuel 1996).

Classification of TRU Waste Tanks. The ability to treat segregated TRU tank waste assumes DOE classifies the waste in at least the 10 underground storage tanks identified as TRU waste (Colburn 1995).

Negligible Impact On Current TWRS Operations. It is assumed there is a negligible impact on current TWRS operations to maintain segregated TRU insoluble waste stream. Based on this assumption it is permissible to transfer and store non-complexed supernatant waste on top of TRU sludge which mitigates most waste volume management and waste compatibility issues. This assumption defines the lower bound cost of TWRS Operations before retrieval. Any deviations from this assumption necessary to maintain TRU waste segregated will only increase TWRS Operations complexity and cost.

No Impact On Waste Retrieval Project. For this analysis it is assumed there is no impact on the Waste Retrieval Project resulting from segregating TRU waste. Although it is clear this is an oversimplification, conclusions can be drawn from the analysis without quantifying retrieval impacts (see Section 6.5.1.2.4). This assumption defines the lower bound cost of the Waste Retrieval Project. Any deviations from this assumption necessary to retrieve TRU waste while maintaining segregation will only increase retrieval complexity and cost. Qualitatively, retrieval of segregated TRU waste would cause some impact on retrieval complexity and cost due to segregation requirements, early scheduling needs of TRU waste, and retrieval inefficiencies.

No Physical Impacts On Blending. It is assumed segregation of TRU waste will not require additional equipment for blending. However, TRU segregation does impact blended waste compositions and glass compositions resulting in increased glass volume.

No Impacts On Pretreatment Of HLW/TRU Sludge. The pretreatment of HLW/TRU sludge is not expected to be impacted by the segregation of TRU waste. In general, the sludge washing process is independent of tank blending or segregation. 
WHC-SD-WM-ES-368

Revision 0

No Impacts On LAW Treatment. This analysis assumes there is no impact on LAW treatment since there is a negligible difference in LAW volume and composition if TRU waste is segregated.

HLW And TRU Waste Vitrified In Same Facility. It is assumed that HLW and TRU waste can be vitrified in the same facility with only minor modifications (Crawford and Manuel 1996). The two waste types would be processed in campaigns to minimize cross contamination. The optimal case would be to process the TRU waste first to prevent contaminating the TRU waste with HLW.

Negligible Cost Difference To Meet Disposal Criteria. This analysis assumes there is a negligible cost difference to meet waste acceptance requirements for WIPP (WIPPWAC) and the geologic repository. Although an additional set of documentation would be required for TRU waste bound for WIPP, this type of documentation is not unique to the Hanford site

Immobilization of TRU Waste in HLW Facility. It is assumed that immobilization of TRU waste in the planned HLW vitrification facility would be more cost effective than to perform the immobilization process in a facility designed, built, and operated exclusively for TRU wastes. This assumption is based upon a sunk capital cost including infrastructure and the experience base of borosilicate glass as an acceptable waste form.

Schedule Impact To Meet RH-TRU Waste Emplacement Window At WIPP. This study assumes there is no impact on vitrification operations to immobilize TRU waste by 2021 to meet the RH-TRU waste emplacement window at WIPP. It is assumed that there is no impact associated with retrieval of 10 TRU tanks before 2019.

No Additional Interim Storage For RH-TRU Glass Canisters. Interim storage for RH-TRU glass canisters is not explicitly included in the interim storage cost. TRU waste is assumed to be shipped within one year of its immobilization and therefore does not require dedicated interim storage.

No Additional Cost to Produce Crystalline TRU Waste Form (Case 2b). It is assumed that to produce a TRU crystalline waste form there is no additional development, operation, or capital costs associated with using a steep sloped wall, bottom pour melter necessary to remove the two-phase glass. Although this assumption is not very likely, it does define the lower bounds of the immobilization facility expense and capital costs. Any deviations from this assumption necessary to immobilize segregated TRU waste as a crystalline waste form will only increase the complexity and costs associated with that option.

No Excess Processing Capacity. All cases assume no excess processing capacity to minimize capital costs. 


\subsection{DECISION ACCEPTANCE}

The Hanford Site TRU tank waste will be blended with HLW for disposal in an offsite geologic repository. In the interim, the TRU tank waste will remain stored consistent with the existing safety authorization basis and waste compatibility requirements. The TRU tank waste will not be sent to WIPP for disposal.

The decision is justified based on several decision criteria including cost, volume of waste produced, operability, safety, and technical maturity. There is no cost incentive to segregate TRU tank waste for disposal at WIPP. The additional operating and capital costs required to retrieve, treat, and immobilize segregated TRU tank waste outweigh the savings : gained in disposal cost.

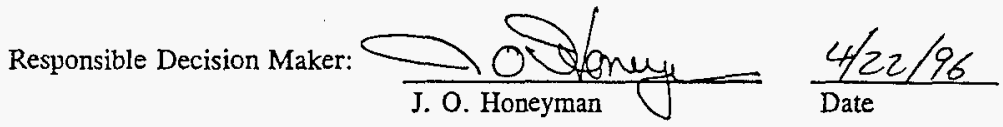

DOE Concurrence:

Decision Action Officer:

$$
\text { W. J. Taylor }
$$

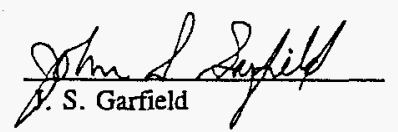

Date

$4-19-96$ 
WHC-SD-WM-ES-368

Revision 0

This page intentionally left blank. 
WHC-SD-WM-ES-368

Revision 0

\subsection{REFERENCES}

Bacon, R. F., 1996, Transmittal of Systems Requirements Review Action Plan to the U.S. Department of Energy, Richland Operations Office, 9650177 , Letter from R. F. Bacon to J. E. Kinzer (dated January 15, 1996), Westinghouse Hanford Company, Richland, Washington.

Boomer, K. D., S. K. Baker, A. L. Boldt, J. D. Galbraith, J. S. Garfield, C. E. Golberg, B. A. Higley, L. J. Johnson, M. J. Kupfer, R. M. Marusich, R. J. Parazin, A. N. Praga, G. W. Reddick, J. A. Reddick, E. J. Slaathaug, L. M. Swanson, T. L. Waldo, and C. E. Worcester, 1993, Tank Waste Technical Options Report, WHC-EP-0616, Westinghouse Hanford Company, Richland, Washington.

Colburn, R. P., 1995, Identification of Potential Transuranic Waste Tanks At The Hanford Site, WHC-SD-WM-ES-331, Westinghouse Hanford Company, Richland, Washington.

Crawford, T. W. and A. F. Manuel, 1996, Technical Feasibility of Transuranic Tank Waste Processing in High-Level Waste Vitrification Facility, WHC-SD-WM-ES-386, Rev. 0, Westinghouse Hanford Company, Richland, Washington.

DOE, 1995, Transuranic Waste Baseline Inventory, Rev. 2, DOE/CAO-95-1121, Volume 1, Carlsbad, New Mexico.

DOE and State of New Mexico, 1981, Agreement for Consultation and Cooperation Between the Department of Energy and the State of New Mexico on the Waste Isolation Pilot Plant, July 1, 1981, U.S. Department of Energy, Washington, D.C.

Ecology, DOE, and EPA, 1994, Hanford Federal Facility Agreement and Consent Order, as amended, Washington State Department of Ecology, U.S. Department of Ecology, U.S. Environmental Protection Agency, and the U.S. Department of Energy, Olympia, Washington.

Kinzer, J. E., 1995, Tank Waste Remediation System (TWRS) Systems Requirements Review Action Plan, 95-TWR-129, (Letter to Dr. A. L. Trego, September 28, 1995), U.S. Department of Energy, Richland Operations Office, Richland, Washington.

Kosiancic, E. J., 1996, Remote Handled Transuranic Volume Estimates From Tank Waste Remediation System, (Letter to D. D. Wodrich, April 1, 1996), Westinghouse Hanford Company, Richland, Washington.

McConville, C. M. and M. E. Johnson, 1995, Decision Analysis Model for Assessment of Tank Waste Remediation System Waste Treatment Strategies, WHC-EP-0874, Westinghouse Hanford Company, Richland, Washington. 
Orme, R.M., 1995, TWRS Process Flowsheet, WHC-SD-WM-TI-613, Rev. 1, Westinghouse Hanford Company, Richland, Washington.

PNNL 1996, R. L. Keeney, D. von Winterfeldt, Value-Based Performance Measures for Hanford Tank Waste Remediation System Program, PNNL-10946, Battelle Pacific Northwest National Laboratory, Richland, Washington.

Taylor, W.J. and K.T. Lang, 1996, Independent Review of Hanford High-Level Waste Volume, memorandum no. 96-WDD-011 dated April 29, 1996, U.S. Department of Energy, Richland Operations Office, Richland, Washington.

WHC, 1995, Tank Waste Remediation System Fiscal-Year 1996 Multi-Year Program Plan . W.B.S. 1.1, WHC-SP-1101 Rev. 1a Vol. 1, Westinghouse Hanford Company, Richland, Washington. 
WHC-SD-WM-ES-368

Revision 0

APPENDIX A

CASE STUDY EVALUATION

A-1 
WHC-SD-WM-ES-368

Revision 0

This page intentionally left blank.

A-2 
Revision 0

\section{APPENDIX A}

\section{CASE STUDY EVALUATION}

This appendix describes how each of the four cases were evaluated against five of the nine decision criteria listed in Section 8.0: (1) total life-cycle cost, (2) life-cycle cost excluding disposal costs, (3) process duration, (4) volume of immobilized HLW produced, and (5) volume of immobilized TRU waste produced. The INSIGHT Model was used with a decision analysis software, Supertree (McConville and Johnson 1995), to perform deterministic and probabilistic evaluations.

The INSIGHT Model case study definitions are discussed in Section A1.0. The algorithms for calculating life-cycle cost, process duration, and immobilized waste volume for the HLW/TRU waste treatment process are presented in Section A2.0. The INSIGHT Model input variables are listed in Section A3.0. The methods for evaluation (i.e., deterministic sensitivity analysis and probabilistic analysis) are described in Section A4.0. The deterministic and probabilistic results of the four case study evaluations are presented in Section A5.0.

\section{A1.0 CASE STUDY DEFINITION}

The user of the INSIGHT Model chooses among options for tank waste inventory, retrieval system, pretreatment process, pretreatment facility, HLW/TRU waste treatment process, HLW/TRU waste form, container size, and LAW form to define the waste treatment strategy to be analyzed. Table A-1 lists the user specified parameters that are common to each of the four cases evaluated. Table A-2 lists the user specified parameters that vary among the four cases. 
WHC-SD-WM-ES-368

Revision 0

Table A-1. INSIGHT Model Case Study Fixed Parameters.

\begin{tabular}{|l|l|}
\hline \multicolumn{1}{|c|}{ User Specified Parameters } & \multicolumn{1}{|c|}{ Cases 1, 2a, 2b, and 2c Fixed Parameters } \\
\hline Tank Waste Inventory & $\begin{array}{l}\text { Inventory specified in TWRS Process Flowsheet, } \\
\text { (Orme 1995) }\end{array}$ \\
\hline Primary SST Retrieval System & 30 Sluicers \\
\hline Secondary SST Retrieval System & 2 Mechanical Arms \\
\hline DST Retrieval System & 2 Mixer Pumps per DST \\
\hline Pretreatment Process & $\begin{array}{l}\text { Enhanced Sludge Wast, Cesium Ion Exchange, } \\
\text { Selective Strontium TRU Element Precipitation }\end{array}$ \\
\hline Pretreatment Facility & New Enhanced Sludge Wash Pretreatment Facility \\
\hline HLW Form & Low-Temperature/Non-Crystalline Glass \\
\hline TRU Waste Container volume & $0.71 \mathrm{~m}^{3}$ \\
\hline HLW Container volume & $1.26 \mathrm{~m}^{3}$ \\
\hline LAW Form & Glass-in-Sulfur \\
\hline
\end{tabular}

DST $=$ Double-shell tank

HLW $=$ High-level waste

LAW $=$ Low-activity waste

SST $=$ Single-shell tank

TRU = Transuranic

TWRS $=$ Tank Waste Remediation System.

Table A-2. INSIGHT Model Case Study Variable Parameters.

\begin{tabular}{|c|c|c|c|c|}
\hline $\begin{array}{c}\text { User specified } \\
\text { parameters }\end{array}$ & $\begin{array}{c}\text { Case 1, } \\
\text { TWRS Process } \\
\text { Flowsheet } \\
\text { (Orme 1995) }\end{array}$ & $\begin{array}{l}\text { Case 2a, } \\
\text { Segregated } \\
\text { TRU Waste }\end{array}$ & $\begin{array}{c}\text { Case } 2 b \text {, } \\
\text { Segregated TRU Waste, } \\
\text { Crystalline Transuranic } \\
\text { Waste Form }\end{array}$ & $\begin{array}{c}\text { Case } 2 \mathrm{c}, \\
\text { Segregated TRU } \\
\text { Waste, } 10.7 \mathrm{MT} / \text { day } \\
\text { Melter }\end{array}$ \\
\hline $\begin{array}{l}\text { High-Level and TRU } \\
\text { Waste Blending }\end{array}$ & Blend & Segregate & Segregate & Segregate \\
\hline Melter Size & $10 \mathrm{MT} /$ day & $10 \mathrm{MT} / \mathrm{day}$ & $10 \mathrm{MT} /$ day & $10.7 \mathrm{MT} /$ day \\
\hline TRU Waste Form & $\begin{array}{c}\text { Non-Crystalline } \\
\text { Glass }\end{array}$ & $\begin{array}{l}\text { Non- } \\
\text { Crystalline } \\
\text { Glass }\end{array}$ & Crystalline & Non-Crystalline Glass \\
\hline
\end{tabular}

TRU $=$ Transuranic

TWRS $=$ Tank Waste Remediation System. 
WHC-SD-WM-ES-368

Revision 0

\section{A2.0 INSIGHT MODEL ALGORITHMS}

This section discusses the input variable relationships for calculating life-cycle cost, process duration, and immobilized waste volume for the HLW/TRU waste treatment process. Some of the original INSIGHT Model algorithms required modification to support the segregation of TRU waste from HLW. The algorithms relevant to the HLW/TRU waste treatment process are listed below, with the modified algorithms marked with an asterisk. The remaining algorithms can be found in Decision Analysis Model for Assessment of Tank Waste Remediation System Waste Treatment Strategies (McConville and Johnson 1995).

The INSIGHT Model cost and volume algorithms have been verified via independent calculations. The volume algorithms for Case 1 were verified by comparing the immobilized HLW and TRU waste volumes with volumes reported in the TWRS Process Flowsheet (Orme 1995). The HLW and TRU waste volume algorithms for Case $2 \mathrm{a}$ were verified against a modified version of the TWRS Process Flowsheet (Orme 1995) that segregated the TRU waste from the HLW (Crawford and Manuel 1996). Cases $2 b$ and $2 c$ used the same HLW and TRU waste volume algorithms as Case $2 \mathrm{a}$, but different input variables (see Table A-2).

\section{A2.1 Life-Cycle Cost Algorithms}

The life-cycle cost calculated for this study does not represent the complete TWRS program costs. The calculated life-cycle cost includes only the HLW/TRU waste disposal elements of the TWRS Program. Costs for SST retrieval, pretreatment, and LAW processing remain the same for all four cases and, therefore, are not included in the lifecycle cost evaluation. The HLW/TRU waste life-cycle cost is a total of the HLW/TRU waste expense, capital, and disposal costs.

The HLW/TRU waste total expense cost includes costs for labor, startup training, consumables, DST retrieval operations, canisters, and facility D\&D, as shown in Table A-3. Case $2 \mathrm{c}$ assumes a slightly larger melter than the other cases and therefore requires a greater labor operating cost than Cases 1, 2a, and $2 b$ (see Section A3.0, Table A-8). The DST retrieval duration also affects the HLW/TRU waste total expense cost. DST retrieval begins once SST retrieval commences and ends when immobilization of the HLW and TRU waste is complete. The consumable cost is based on metric tons of immobilized HLW and TRU waste produced. The same consumable cost per metric ton is used for all four cases.

The HLW and TRU waste canisters differ in volume and cost. The HLW canister holds approximately $1.26 \mathrm{~m}^{3}$ of immobilized waste and costs approximately $\$ 10,000$ (1995 dollars) per canister (Crawford 1995). The WIPP requires the TRU waste to be packaged in a smaller canister that is estimated to hold $0.71 \mathrm{~m}^{3}$ of immobilized waste (Crawford and Manuel 1996) and costs approximately \$7,000 (1995 dollars) per canister. 
Table A-3. High-Level Waste/Transuranic Waste Expense Cost Algorithms.

\begin{tabular}{|c|c|}
\hline Calculated Parameter & Algorithm \\
\hline *Expense Cost & $\begin{array}{l}\text { labor cost }+ \text { startup training cost }+ \text { consumables }+ \text { HLW } \\
\text { container cost }+ \text { TRU waste container cost }+ \text { DST retrieval } \\
\text { operating cost }+ \text { HLW/TRU waste facility D\&D }\end{array}$ \\
\hline Labor cost & $\begin{array}{l}\text { (HLW/TRU waste process duration) } \\
\mathrm{x} \text { (HLW/TRU waste facility labor cost per year) }\end{array}$ \\
\hline Startup training cost & 3 years $\mathrm{x}$ HLW/TRU waste labor cost per year \\
\hline *Consumables cost & $\begin{array}{l}\text { (consumables cost per MT glass produced) } x \text { (MT HLW glass } \\
+ \text { MT TRU waste glass) }\end{array}$ \\
\hline HLW container cost & $\begin{array}{l}\text { (cost per } 1.26 \mathrm{~m}^{3} \text { container) } \mathrm{x} \text { (number of } 1.26 \mathrm{~m}^{3} \text { containers } \\
\text { produced) }\end{array}$ \\
\hline $\begin{array}{l}\text { *TRU waste container } \\
\text { cost }\end{array}$ & $\begin{array}{l}\text { (cost per } 0.71 \mathrm{~m}^{3} \text { container) } \times \text { (number of } 0.71 \mathrm{~m}^{3} \text { containers } \\
\text { produced) }\end{array}$ \\
\hline $\begin{array}{l}\text { DST retrieval operating } \\
\text { cost }\end{array}$ & $\begin{array}{l}\text { (DST retrieval operating cost per year) } \times \text { (HLW completion } \\
\text { date - SST retrieval start date) }\end{array}$ \\
\hline $\begin{array}{l}\text { HLW/TRU waste facility } \\
\text { D\&D cost }\end{array}$ & $\begin{array}{l}\text { (0.3) } \times \text { (HLW/TRU waste facility construction cost) } \\
+(3 \text { years }) \times \text { (HLW/TRU waste facility labor cost per year) }\end{array}$ \\
\hline
\end{tabular}

*Indicates a modification of algorithms reported in Decision Analysis Model for Assessment of Tank Waste Remediation System Waste Treatment Strategies, (McConville and Johnson 1995)

$\begin{array}{lll}\text { D\&D } & =\text { Decontamination and Decommissioning } \\ \text { DST } & =\text { Double-shell tank } \\ \text { HLW } & =\text { High-level waste } \\ \text { TRU } & =\text { Transuranic. }\end{array}$

The HLW/TRU waste total capital cost includes costs for construction of the process facility, construction of interim storage buildings, and melter replacements, as shown in Table A-4. The number of interim storage buildings required are based on a building capacity of 1,330 containers with a volume of $1.26 \mathrm{~m}^{3}$. The interim storage building costs apply to the HLW only. The TRU waste segregation cases assume the TRU waste is processed before the HLW, and shipped within one year of its immobilization. Before shipment, the TRU waste containers would be stored in the HLW interim storage buildings. The total melter replacement cost is based on the melter life and the required process duration excluding down time for replacement. The melter life is assumed to be two years with a five month replacement period, based on HWVP and Defense Waste Processing Facility assumptions (WHC 1992 and WSRC 1995). 
WHC-SD-WM-ES-368

Revision 0

Table A-4. High-Level Waste/Transuranic Waste Capital Cost Algorithms.

\begin{tabular}{|l|l|}
\hline Calculated parameter & \multicolumn{1}{c|}{ Algorithm } \\
\hline *Capital cost & $\begin{array}{l}\text { HLW/TRU waste facility construction cost + interim storage } \\
+ \text { melter replacement cost }\end{array}$ \\
\hline $\begin{array}{l}\text { Interim storage } \\
\text { building construction } \\
\text { cost }\end{array}$ & $\begin{array}{l}\text { [Round up to nearest whole number: (number of HLW containers } \\
\text { produced)/(number of HLW containers per interim storage } \\
\text { building)] x (Construction cost per interim storage building) }\end{array}$ \\
\hline $\begin{array}{l}* \text { Melter replacement } \\
\text { cost }\end{array}$ & $\begin{array}{l}\text { [Round to nearest whole number: (HLW/TRU waste process } \\
\text { duration excluding melter replacements)/(melter life)] x (cost per } \\
\text { melter replacement) }\end{array}$ \\
\hline
\end{tabular}

*Indicates modification of algorithms reported in Decision Analysis Model for Assessment of Tank Waste Remediation System Waste Treatment Strategies (McConville and Johnson 1995).

HLW $=$ High-level waste

TRU $=$ Transuranic.

The HLW and TRU waste disposal costs are based on the number of canisters produced, as shown in Table A-5. The HLW disposal cost is estimated at $\$ 356,000$ per $0.62 \mathrm{~m}^{3}$ canister (1995 dollars) by the DOE OCRWM (DOE-RW 1995). This study assumes a HLW container volume of $1.26 \mathrm{~m}^{3}$ (Crawford 1995). Based on previous HLW disposal cost estimates by DOE (DOE-RW 1993), this study assumes the disposal cost for $1.26-\mathrm{m}^{3}$ canisters is 10 percent greater than the $0.62-\mathrm{m}^{3}$ canister disposal cost.

Table A-5. High-Level Waste/Transuranic Waste Disposal Cost Algorithms.

\begin{tabular}{|l|l|}
\hline \multicolumn{1}{|c|}{ Calculated parameter } & \multicolumn{1}{c|}{ Algorithm } \\
\hline $\begin{array}{l}\text { High-level waste } \\
\text { disposal cost }\end{array}$ & $\begin{array}{l}\text { (disposal cost per } 1.26-\mathrm{m}^{3} \text { high-level waste canister) } \\
\mathrm{x} \text { (number of } 1.26-\mathrm{m}^{3} \text { containers produced) }\end{array}$ \\
\hline $\begin{array}{l}\text { *Transuranic waste } \\
\text { disposal cost }\end{array}$ & $\begin{array}{l}\text { (disposal cost per } 0.71-\mathrm{m}^{3} \text { container) } \mathrm{x} \text { (number of } 0.71-\mathrm{m}^{3} \\
\text { containers produced) }\end{array}$ \\
\hline
\end{tabular}

*Indicates modification of algorithms reported in Decision Analysis Model for Assessment of Tank Waste Remediation System Waste Treatment Strategies (McConville and Johnson 1995). 
WHC-SD-WM-ES-368

Revision 0

\section{A2.2 Process Duration Algorithms}

The HLW/TRU waste immobilization process may not begin before pretreatment begins and the facility operates until all wastes have been treated. The HLW process startup date is calculated as the maximum of the HLW availability date or the pretreatment startup date. The HLW/TRU waste process facility availability date reflects the Hanford Federal Facility Agreement and Consent Order (Tri-Party Agreement) (Ecology et al. 1994) date of December 2009 (Tri-Party Agreement Milestone M-51-03) for startup of HLW/TRU waste hot operations.

The HLW/TRU waste process duration is derived from the total mass throughput, total operating efficiency, duration required for melter replacement, and the quantity of waste treated, as shown below in Table A-6. The parameter "percent operating time" represents the percentage of the process duration when the melter is actually in operation.

Table A-6. High-Level Waste/Transuranic Process Duration Algorithms.

\begin{tabular}{|c|c|}
\hline Calculated parameter & Equation \\
\hline $\begin{array}{l}\text { HLW/TRU waste } \\
\text { process startup date }\end{array}$ & $\begin{array}{l}\text { Maximum of } \\
\text { HLW/TRU waste vitrification facility availability date } \\
\text { or } \\
\text { Pretreatment startup date }\end{array}$ \\
\hline $\begin{array}{l}\text { *percent operating } \\
\text { time }\end{array}$ & melter life/(melter life + melter replacement duration) \\
\hline \multirow[t]{2}{*}{$\begin{array}{l}\text { *HLW/TRU waste } \\
\text { process duration }\end{array}$} & $\begin{array}{l}\text { Cases } 1,2 a, 2 b \\
\text { (quantity of HLW containers + quantity of TRU waste } \\
\text { containers)/[(\% operating time)x(total operating } \\
\text { efficiency)x(container per year facility throughput) }]\end{array}$ \\
\hline & $\begin{array}{l}\text { Case } 2 \mathrm{c} \\
\text { (mass of HLW glass }+ \text { mass of TRU waste glass)/[(\% operating } \\
\text { time) } x \text { (total operating efficiency) } x \text { (mass per year melter } \\
\text { throughput)] }\end{array}$ \\
\hline $\begin{array}{l}\text { HLW/TRU waste } \\
\text { process completion } \\
\text { date }\end{array}$ & $\begin{array}{l}\text { HLW/TRU waste process startup date }+ \text { HLW/TRU waste } \\
\text { duration }\end{array}$ \\
\hline
\end{tabular}

*Indicates modification of algorithms reported in Decision Analysis Model for Assessment of Tank Waste Remediation System Waste Treatment Strategies (McConville and Johnson 1995).

HLW $=$ High-level waste

TRU $=$ Transuranic. 
The HLW/TRU waste process duration was calculated using an annual container throughput for Cases $1,2 \mathrm{a}$, and $2 \mathrm{~b}$, and an annual mass throughput for Case 2c. For Case 1 , the annual mass throughput is equal to the annual container throughput. The segregated TRU waste Cases $(2 \mathrm{a}, 2 \mathrm{~b}, 2 \mathrm{c})$ require a separate, smaller volume container for the TRU waste. Cases $2 \mathrm{a}$ and $2 \mathrm{~b}$ assume the TRU waste annual canister throughput is the same as the HLW annual canister throughput (i.e., Cases $2 a$ and $2 b$ are limited by canister handling). The Case $2 c$ process duration algorithm is based on annual mass throughput and assumes increased canister handling to accommodate the mass throughput.

\section{A.2.3 Immobilized Waste Volume Algorithms}

The composition of the immobilized HLW/TRU waste form must meet several criteria such as durability, minimization of radionuclide leaching, thermal output, etc. The quantity of waste oxides incorporated into the immobilized HLW/TRU waste form, along with the immobilizing materials, will influence the ability to meet these criteria. Cases $1,2 \mathrm{a}$, and $2 \mathrm{c}$ assume non-crystalline glass as the immobilized HLW/TRU waste form. Case $2 \mathrm{~b}$ assumes a crystalline TRU waste form and non-crystalline glass as the HLW form. The crystalline and non-crystalline waste forms have different waste oxide concentration limits. The volume of HLW produced is a function of the total mass of oxides in the pretreated HLW, and waste oxide limits for individual components, as shown in Table A-7. 
WHC-SD-WM-ES-368

Revision 0

Table A-7. Immobilized Waste Volume Algorithms.

\begin{tabular}{|c|c|}
\hline Calculated Parameter & Equation \\
\hline $\begin{array}{l}\text { Waste oxide loading } \\
\text { limit }\end{array}$ & $\begin{array}{l}100 \text { percent - minimum } \mathrm{SiO}_{2} \text { concentration limit - minimum } \mathrm{B}_{2} \mathrm{O}_{3} \\
\text { concentration limit - minimum } \mathrm{Li}_{2} \mathrm{O} \text { concentration limit }\end{array}$ \\
\hline $\begin{array}{l}\text { Number of } 1.26 \mathrm{~m}^{3} \\
\text { HLW containers } \\
\text { produced }\end{array}$ & $\begin{array}{l}\text { Maximum of } \\
\text { [sum of(mass of component } \mathrm{i} \text { oxide in pretreated } \\
\text { HLW)/(component } \mathrm{i} \text { concentration limit)x(HLW mass per } \\
\text { container)] } \\
\text { or } \\
\text { [(total mass of oxides in pretreated } \mathrm{HLW}) /(\text { waste oxide } \\
\text { loading limit) } x \text { (HLW mass per container)] }\end{array}$ \\
\hline $\begin{array}{l}\text { *Number of } 0.71 \mathrm{~m}^{3} \\
\text { TRU waste containers } \\
\text { produced }\end{array}$ & $\begin{array}{l}\text { Maximum of } \\
\text { [sum of(mass of component } \mathrm{i} \text { oxide in pretreated TRU } \\
\text { waste)/(component } \mathrm{i} \text { waste concentration limit)x(TRU waste } \\
\text { mass per container)] } \\
\text { or } \\
\text { [(total mass of oxides in pretreated TRU waste)/(waste oxide } \\
\text { loading limit)x(TRU waste glass per container)] }\end{array}$ \\
\hline $\begin{array}{l}\text { Volume }\left(\mathrm{m}^{3}\right) \text { of } \\
\text { immobilized HLW } \\
\text { glass produced }\end{array}$ & $\begin{array}{l}\text { (Quantity of HLW containers produced) } x\left(1.26 \mathrm{~m}^{3} \text { glass per }\right. \\
\text { container) }\end{array}$ \\
\hline $\begin{array}{l}\text { *Volume }\left(\mathrm{m}^{3}\right) \text { of } \\
\text { immobilized TRU } \\
\text { glass produced }\end{array}$ & $\begin{array}{l}\text { (Quantity of TRU waste containers produced) } \times\left(0.71 \mathrm{~m}^{3} \text { glass per }\right. \\
\text { container) }\end{array}$ \\
\hline
\end{tabular}

*Indicates modification of algorithms reported in McConville and Johnson (1995)

HLW $=$ High-level waste

TRU $=$ Transuranic. 


\section{Revision 0}

\section{A3.0 INSIGHT MODEL INPUT VARIABLES}

The INSIGHT Model includes values with specified uncertainty ranges for variables such as facility construction and operation costs; process start-up and completion dates; and the fraction of waste components separated and sent to LLW and HLW treatment. Each variable range is defined in terms of a base condition (i.e., mid value) and a high and low modifier that represent the range of the technical uncertainty. The variable ranges are estimates based on evaluation of available engineering information by knowledgeable technical personnel (e.g., contingency included in architectural engineering conceptual designs, cost estimates for facilities, range of tank waste sludge components dissolved by caustic).

The original list of input variables reported in Decision Analysis Model for Assessment of Tank Waste Remediation System Waste Treatment Strategies (McConville and Johnson 1995) has been specifically modified to support the evaluation of waste treatment alternatives which maintain the segregation of TRU waste from HLW. The uncertainty ranges for each input variable relevant to the HLW/TRU waste treatment process are listed in Tables A-8, A-9, and A-10, with the modified variables marked with an asterisk. 
WHC-SD-WM-ES-368

Revision 0

Table A-8. Life-Cycle Cost Input Variables. (2 Sheets)

\begin{tabular}{|c|c|c|c|c|c|}
\hline \multirow{2}{*}{$\begin{array}{c}\text { Technical } \\
\text { uncertainties }\end{array}$} & \multirow{2}{*}{ Description } & \multicolumn{3}{|c|}{$\begin{array}{l}\text { Range of solution for technical } \\
\text { uncertainty }\end{array}$} & \multirow[t]{2}{*}{$\begin{array}{c}\text { Spreadsheet variable } \\
\text { name }\end{array}$} \\
\hline & & $\begin{array}{l}\text { Low-range } \\
\text { value }\end{array}$ & $\begin{array}{l}\text { Mid-range } \\
\text { value }\end{array}$ & $\begin{array}{l}\text { High-range } \\
\text { value }\end{array}$ & \\
\hline \multirow[t]{2}{*}{$\begin{array}{l}\text { HLW/TRU waste } \\
\text { facility construction } \\
\text { cost } \\
\text { (Millions of } 1995 \\
\text { dollars) }\end{array}$} & $\begin{array}{l}10 \mathrm{MT} / \text { day Joule-heated melter facility } \\
\text { construction cost from WHC-SD-WM-ES-295, } \\
\text { page } 75 \text { (Boomer et al. 1994). The base } \\
\text { estimate was determined from Kaiser } \\
\text { Interactive Estimating (IEST) job } \# 436302 \text { and } \\
\text { assumes a } 40 \text { percent contingency. The high- } \\
\text { range value is } 25 \text { percent greater than the base } \\
\text { estimate and the low-range value assumes a } \\
25 \text { percent contingency. }\end{array}$ & 1673 & 1873 & 2342 & \multirow[t]{2}{*}{ hiwconstcost } \\
\hline & $\begin{array}{l}10.7 \mathrm{MT} / \text { day Joule-heated melter facility } \\
\text { construction cost determined from Kaiser IEST } \\
\text { job \#E11523/Z395. The } 10.7 \mathrm{MT} / \text { day facility } \\
\text { cost base estimate assumes a } 40 \text { percent } \\
\text { contingency, and is } \$ 100 \text { million (1995 dollars) } \\
\text { greater than the } 10 \mathrm{MT} / \text { day facility base } \\
\text { estimate. The } \$ 100 \text { million difference is based } \\
\text { on the difference between Kaiser IEST job } \\
\# \mathrm{E} 11523 / 2395 \text { and job \#436302. The high- } \\
\text { range value is } 25 \text { percent greater than the base } \\
\text { estimate and the low-range value assumes a } \\
25 \text { percent contingency. }\end{array}$ & $* 1762$ & 1973 & $* 2467$ & \\
\hline $\begin{array}{l}\text { Facility Modification } \\
\text { Cost } \\
\text { (Millions of } 1995 \\
\text { dollars) }\end{array}$ & $\begin{array}{l}\text { Facility Modification Cost to process TRU } \\
\text { waste separately from HLW is an additional } \\
\text { cost to the HLW facility construction cost and } \\
\text { is only applicable if TRU waste is segregated } \\
\text { from HLW (Craw ford and Manuel 1996). }\end{array}$ & $*_{2.1}$ & $*_{2.1}$ & $*_{2.1}$ & trumodcost \\
\hline $\begin{array}{l}\text { Interim storage } \\
\text { building construction } \\
\text { cost } \\
\text { (Millions of } 1995 \\
\text { dollars per building) }\end{array}$ & $\begin{array}{l}\text { Construction cost per interim storage building } \\
\text { from WHC-EP-0616, p. R-250 (Boomer et } \\
\text { al. 1993). Cost per building assumes } 1330 \\
\text { HLW canisters }\left(1.26 \mathrm{~m}^{3}\right) \text { per storage building } \\
\text { and no additional interim storage required for } \\
\text { TRU waste canisters }\left(0.71 \mathrm{~m}^{3}\right) \text {. }\end{array}$ & 106.1 & 1061 & 106.1 & interimstor \\
\hline \multirow[t]{2}{*}{$\begin{array}{l}\text { HLW/TRU waste } \\
\text { facility labor cost per } \\
\text { year } \\
\text { (Millions of } 1995 \\
\text { dollars/yr) }\end{array}$} & $\begin{array}{l}10 \text { MT/day facility: } \\
\text { The low-range value represents the staffing cost } \\
\text { for one facility from WHC-SD-WM-ES-295, } \\
\text { page } 77 \text { (Boomer et al. 1994) escalated to } 1995 \\
\text { dollars. The high-range value represents the } \\
\text { staffing cost for the HWVP Joule-heated melter } \\
\text { from WHC-EP-0616, page R-378 (Boomer et } \\
\text { al. 1993) escalated to } 1995 \text { dollars. The mid- } \\
\text { range value is the midpoint between the low } \\
\text { and high values. }\end{array}$ & $*_{47}$ & $* 60$ & $* 73$ & \multirow[t]{2}{*}{ hlwopcost } \\
\hline & $\begin{array}{l}10.7 \mathrm{MT} / \text { day facility: } \\
\text { The base estimate staffing costs are assumed to } \\
\text { be } 10 \text { percent greater than the } 10 \mathrm{MT} / \mathrm{day} \\
\text { facility. The high-range value is } 25 \text { percent } \\
\text { greater than the bose estimate and the low- } \\
\text { range value assumes a } 25 \text { percent contingency. }\end{array}$ & $* 59$ & $* 66$ & $* 83$ & \\
\hline
\end{tabular}


Table A-8. Life-Cycle Cost Input Variables. (2 Sheets)

\begin{tabular}{|c|c|c|c|c|c|}
\hline \multirow{2}{*}{$\begin{array}{c}\text { Technical } \\
\text { uncertainties }\end{array}$} & \multirow{2}{*}{ Description } & \multicolumn{3}{|c|}{$\begin{array}{l}\text { Range of solution for technical } \\
\text { uncertainty }\end{array}$} & \multirow[t]{2}{*}{$\begin{array}{c}\text { Spreadsheet variable } \\
\text { name }\end{array}$} \\
\hline & & $\begin{array}{l}\text { Low-range } \\
\text { value }\end{array}$ & $\begin{array}{l}\text { Mid-range } \\
\text { value }\end{array}$ & $\begin{array}{l}\text { High-range } \\
\text { value }\end{array}$ & \\
\hline $\begin{array}{l}\text { DST retrieval } \\
\text { operating cost } \\
\text { (millions of } 1995 \\
\text { dollars per year) }\end{array}$ & $\begin{array}{l}\text { Annual operating cost for mixer pump retrieval } \\
\text { is } \$ 48 \text { million (1995 dollars) from FY } 1996 \\
\text { TWRS MYPP, WHC-SP-1101, Rev. } 1 \text {. The } \\
\text { high-range value is } 10 \text { percent greater than the } \\
\text { base estimate, and the low-range value is } 10 \\
\text { percent fess than the base estimate. DST } \\
\text { retrieval continues throughout the HLW/TRU } \\
\text { waste immobilization process. }\end{array}$ & $* 43$ & * 48 & $* 53$ & dstopcost \\
\hline $\begin{array}{l}\text { Consumables cost per } \\
\text { MT immobilized } \\
\text { waste } \\
\text { (1995 dollars } \\
\text { per MT immobilized } \\
\text { waste) }\end{array}$ & $\begin{array}{l}\text { The consumable operating cost is based on the } \\
\text { mid-point of annual consumable operating costs } \\
\text { for a } 10 \mathrm{MT} / \text { day Joule-heated melter (Boomer } \\
\text { et al. 1994, page } 77 \text {, escalated to } 1995 \text { dollars) } \\
\text { and the HWVP melter (Boomer et al. } 1993 \text {, } \\
\text { page R-378, excluding errors identified in } \\
\text { utility costs and escalated to } 1995 \text { dollars). The } \\
\text { consumable cost per MT of glass produced was } \\
\text { determined by multiplying the mid-point } \\
\text { consumable cost per year and the TWRS } \\
\text { Process Flowsheet Rev. } 1 \text { Case HLW process } \\
\text { duration then dividing by the total mass of } \\
\text { HCW glass produced (i.e., } \$ 28 \mathrm{M} / \text { year } \mathrm{x} \\
13 \text { years/23,860 MT glass = } \$ 15,300 / \mathrm{MT} \text { glass } \\
\text { produced). The high-range value is } 25 \text { percent } \\
\text { greater than the base estimate, and the low- } \\
\text { range value assumes a } 25 \text { percent contingency. }\end{array}$ & $* 13,660$ & $*_{15}, 300$ & $* 19,125$ & hlwchemcost \\
\hline $\begin{array}{l}\text { Melter Replacement } \\
\text { Cost } \\
\text { (millions of } 1995 \\
\text { dollars per melter } \\
\text { replaced) }\end{array}$ & $\begin{array}{l}\text { Cost per metter replaced is } \$ 39 \text { million (1995 } \\
\text { dollars). The life span of a melter is estimated } \\
\text { to be } 2 \text { years (WSRC 1995, page 54). }\end{array}$ & 39 & 39 & 39 & meltrep \\
\hline \multirow{2}{*}{$\begin{array}{l}\text { Canister Costs } \\
\text { (thousands of } 1995 \\
\text { dollars per canister) }\end{array}$} & HLW Canister cost for $1.26 \mathrm{~m}^{3}$ canister. & 10 & 10 & 10 & hlwconcost \\
\hline & $\begin{array}{l}\text { Transuranic (TRU) Waste Canister cost for } \\
0.71 \mathrm{~m}^{3} \text { canister from (Crawford and Manuel } \\
\text { 1996). Low and mid-range values do not } \\
\text { include overpack and concrete shielding for pad } \\
\text { storage. High-range value includes overpack } \\
\text { and concrete shielding. }\end{array}$ & $* 7.2$ & 772 & $* 8.6$ & truconcost \\
\hline \multirow[t]{2}{*}{$\begin{array}{l}\text { Disposal Cost } \\
\text { (thousands of } 1995 \\
\text { dollars per canister) }\end{array}$} & $\begin{array}{l}\text { HLW Disposal Cost: The disposal cost for a } \\
1.26 \mathrm{~m}^{3} \text { HLW canister is assumed to be } 10 \\
\text { percent greater than the disposal cost for a } 0.62 \\
\mathrm{~m}^{3} \text { canister (DOE/RW 1993). The disposal } \\
\text { cost for the } 0.62 \mathrm{~m}^{3} \text { canister is } \$ 356,000 \text { per } \\
\text { canister (DOE/RW } 1995 \text { ) }\end{array}$ & *392 & $* 392$ & $* 392$ & candis \\
\hline & $\begin{array}{l}\text { TRU Waste Disposal Cost: The low and mid- } \\
\text { range disposal cost per } 0.71 \mathrm{~m}^{3} \text { canister is } \\
\text { estimated from a July } 1995 \mathrm{WIPP} \text { presentation, } \\
\text { (DOE-EM 1995). The high-range value is } 20 \\
\text { percent greater than the mid-range value. }\end{array}$ & $* 30$ & ${ }^{*} 30$ & $*_{36}$ & trudis \\
\hline
\end{tabular}

*Indicates a modification of variables reported in McConville and Johnson (1995). Shaded cells indicate "Base Case" values. 
WHC-SD-WM-ES-368

\section{Revision 0}

Table A-9. Process Duration Input Variables.

\begin{tabular}{|c|c|c|c|c|c|}
\hline \multirow[b]{2}{*}{ Technical uncertaintics } & \multirow{2}{*}{ Description } & \multicolumn{3}{|c|}{$\begin{array}{l}\text { Range of solution for technical } \\
\text { uncertainty }\end{array}$} & \multirow{2}{*}{$\begin{array}{c}\text { Spreadsheet } \\
\text { variable name }\end{array}$} \\
\hline & & $\begin{array}{l}\text { Low-range } \\
\text { value }\end{array}$ & $\begin{array}{l}\text { Mid-range } \\
\text { value }\end{array}$ & $\begin{array}{l}\text { High- } \\
\text { range } \\
\text { value }\end{array}$ & \\
\hline \multirow[t]{2}{*}{$\begin{array}{l}\text { High-level waste } \\
\text { (HLW) melter } \\
\text { throughput }(\mathrm{kg} / \mathrm{h})\end{array}$} & $\begin{array}{l}10 \mathrm{MT} / \text { day melter throughput in } \mathrm{kg} / \mathrm{hour} \text {. } \\
\text { The high-range estimate is } 15 \text { percent } \\
\text { greater than the base estimate. The low- } \\
\text { range estimate is } 15 \text { percent less than the } \\
\text { base estimate. }\end{array}$ & 354 & 417 & 479 & \multirow[t]{2}{*}{ hlwthput } \\
\hline & $\begin{array}{l}10.7 \mathrm{MT} / \text { day melter throughput in } \\
\mathrm{kg} / \mathrm{hour} \text {. The high-range estimate is } \\
15 \text { percent greater than the base estimate. } \\
\text { The low-range estimate is } 15 \text { percent less } \\
\text { than the base estimate. }\end{array}$ & *377 & $*_{444}$ & $*_{511}$ & \\
\hline $\begin{array}{l}\text { HLW facility total } \\
\text { operating efficiency } \\
\text { (TOE) }\end{array}$ & $\begin{array}{l}\text { Total operating efficiency (TOE) for } \\
10 \mathrm{MT} / \text { day facility and } 10.7 \mathrm{MT} / \text { day } \\
\text { facility }\end{array}$ & $50 \%$ & $60 \%$ & $70 \%$ & capfac \\
\hline $\begin{array}{l}\text { Melter life } \\
\text { (years) }\end{array}$ & $\begin{array}{l}\text { The life span of } 10 \mathrm{MT} / \text { day or } \\
10.7 \text { MT/day Joule-heated melter is } \\
\text { estimated to be } 2 \text { years in the Savannah } \\
\text { River Stte HLW System Plan, Rev.5, } \\
\text { page } 54 \text { (WSRC 1995) and the HWVP } \\
\text { Technical Data Package, Volume } 2 \\
\text { (WHC 1992). }\end{array}$ & $*_{1}$ & $*_{2}$ & $*_{3}$ & hlwunitlife \\
\hline $\begin{array}{l}\text { Metter replacement } \\
\text { duration } \\
\text { (months) }\end{array}$ & $\begin{array}{l}\text { Duration required to allow for melter } \\
\text { replacement at end of melter life. Five } \\
\text { months for replacement and restart is } \\
\text { assumed (WSRC 1995). }\end{array}$ & $*_{5}$ & $* 5$ & $*_{5}$ & outagedur \\
\hline $\begin{array}{l}\text { HLW/TRU waste } \\
\text { availability date }\end{array}$ & $\begin{array}{l}\text { Availability date for } 10 \mathrm{MT} / \text { day facility } \\
\text { and } 10+\mathrm{MT} / \text { day facility. Tri-Party } \\
\text { Agreement Milestone M-51-03 (HLW } \\
\text { process stant date) is December } 2009 \text {. }\end{array}$ & 2008 & 2009 & 2010 & hlwyear \\
\hline SST retrieval start date & $\begin{array}{l}\text { Year SST retrieval begins is based on Tri- } \\
\text { Party Agrcement Milestone M-45-05-T01 } \\
\text { which specifies initiating tank waste } \\
\text { retrieval from one SST } 12 / 31 / 2003 \text {. } \\
\text { INSIGHT Model assumes DST retrieval } \\
\text { operations begin when SST retrieval } \\
\text { begins, and end when HLW processing } \\
\text { ends. }\end{array}$ & 2004 & 2005 & 2006 & vSSTretstart \\
\hline Pretreatment start date & $\begin{array}{l}\text { Pretreatment is assumed to begin one year } \\
\text { after retrieval operations begin. }\end{array}$ & 2005 & 2007 & 2009 & preyear \\
\hline
\end{tabular}

*Indicates a modification of variables reported in McConville and Johnson (1995). Shaded cells indicate "Base Case" values. 
WHC-SD-WM-ES-368

Revision 0

Table A-10. Immobilized Waste Volume Input Variables. (2 Sheets)

\begin{tabular}{|c|c|c|c|c|c|}
\hline \multirow[b]{2}{*}{$\begin{array}{c}\text { Technical } \\
\text { uncertainties }\end{array}$} & \multirow[b]{2}{*}{ Description } & \multicolumn{3}{|c|}{$\begin{array}{c}\text { Range of solution for technical } \\
\text { uncertainty }\end{array}$} & \multirow[b]{2}{*}{$\begin{array}{l}\text { Spreadsheet } \\
\text { variable name }\end{array}$} \\
\hline & & $\begin{array}{l}\text { Low- } \\
\text { range } \\
\text { value }\end{array}$ & $\begin{array}{l}\text { Mid-range } \\
\text { value }\end{array}$ & $\begin{array}{l}\text { High- } \\
\text { range } \\
\text { value }\end{array}$ & \\
\hline \multirow{2}{*}{$\begin{array}{l}\mathrm{SiO}_{2} \text { minimum } \\
\text { immobilized } \\
\mathrm{HLW} / \mathrm{TRU} \text { waste } \\
\text { concentration limit }\end{array}$} & $\begin{array}{l}\text { Crystalline } \mathrm{HLW} / \mathrm{TRU} \text { waste form } \\
\text { minimum } \mathrm{SiO}_{2} \text { concentration limit. } \\
\text { (Glass Chemistry Workshop 1995) }\end{array}$ & $37 \%$ & $40 \%$ & $45 \%$ & \multirow[t]{2}{*}{$\mathrm{VSiO} 2$} \\
\hline & $\begin{array}{l}\text { Non-crystalline low temperature } \\
\mathrm{HLW} / \mathrm{TRU} \text { waste glass minimum } \mathrm{SiO}_{2} \\
\text { concentration limit. (Glass Chemistry } \\
\text { Workshop 1995) }\end{array}$ & $37 \%$ & $42 \%$ & $47 \%$ & \\
\hline \multirow{2}{*}{$\begin{array}{l}\mathrm{B}_{2} \mathrm{O}_{3} \text { minimum } \\
\text { immobilized } \\
\text { HLW/TRU waste } \\
\text { concentration limit }\end{array}$} & $\begin{array}{l}\text { Crystalline HLW/TRU waste form } \\
\text { minimum Boron concentration limit. } \\
\text { (Glass Chemistry Workshop 1995) }\end{array}$ & $0 \%$ & $3 \%$ & $5 \%$ & \multirow[t]{2}{*}{ vBoron } \\
\hline & $\begin{array}{l}\text { Non-crystalline low ternperature } \\
\text { HLW/TRU waste glass minimum Boron } \\
\text { concentration limit (Glass Chemistry } \\
\text { Workshop 1995). }\end{array}$ & $0 \%$ & $3 \%$ & $5 \%$ & \\
\hline $\begin{array}{l}\mathrm{Li}_{2} \mathrm{O} \text { minimum } \\
\text { immobilized } \\
\mathrm{HLW} / \mathrm{TRU} \text { waste } \\
\text { concentration limit }\end{array}$ & $\begin{array}{l}\text { Minimum } \mathrm{Li}_{2} \mathrm{O} \text { concentration limit for } \\
\text { crystalline or non-crystalline } \\
\text { HLW/TRU waste form (Orme 1995). }\end{array}$ & $2 \%$ & $2 \%$ & $2 \%$ & \\
\hline \multirow[t]{2}{*}{$\begin{array}{l}\mathrm{Al}_{2} \mathrm{O}_{3} \text { Maximum } \\
\text { immobilized } \\
\text { HLW/TRU waste } \\
\text { concentration limit }\end{array}$} & $\begin{array}{l}\text { Crystalline } \mathrm{HLW} / \mathrm{TRU} \text { waste form } \\
\text { maximum } \mathrm{Al}_{2} \mathrm{O}_{3} \text { concentration limit } \\
\text { (Glass Chemistry Workshop 1995). }\end{array}$ & $20 \%$ & $25 \%$ & $35 \%$ & \multirow[t]{2}{*}{ valhlwlim } \\
\hline & $\begin{array}{l}\text { HWVP Non-crystalline low-temperature } \\
\mathrm{HLW} \text { TRU waste glass maximum } \mathrm{Al}_{2} \mathrm{O}_{3} \\
\text { concentration limit (Orme 1995). }\end{array}$ & $10 \%$ & $11 \%$ & $15 \%$ & \\
\hline \multirow[t]{2}{*}{$\begin{array}{l}\mathrm{Cr}_{2} \mathrm{O}_{3} \text { Maximum } \\
\text { immobilized } \\
\text { HLW/TRU waste } \\
\text { concentration limit }\end{array}$} & $\begin{array}{l}\text { Crystalline } \mathrm{HLW} \text {.TRU waste form } \\
\text { maximumm } \mathrm{Cr}_{2} \mathrm{O}_{3} \text { concentration limit } \\
\text { (Glass Chemistry Workshop 1995). }\end{array}$ & $2 \%$ & $5 \%$ & $8 \%$ & \multirow[t]{2}{*}{ vcrhlwlim } \\
\hline & $\begin{array}{l}\text { Hanford waste vitrification plant } \\
\text { (HWVP) Non-crystalline low- } \\
\text { temperature } \mathrm{HLW} / \mathrm{TRU} \text { waste glass } \\
\text { maximum } \mathrm{Cr}_{2} \mathrm{O}_{3} \text { concentration limit } \\
\text { (Orme 1995). }\end{array}$ & $0.3 \%$ & $0.5 \%$ & $0.7 \%$ & \\
\hline \multirow[t]{2}{*}{$\begin{array}{l}\mathrm{Na}_{2} \mathrm{O} \text { Maximum } \\
\text { immobilized } \\
\text { HLW/TRU waste } \\
\text { concentration limit }\end{array}$} & $\begin{array}{l}\text { Crystalline HLW/TRU waste form } \\
\text { maximum Na } \mathrm{O} \text { concentration limit } \\
\text { (Glass Chemistry Workshop 1995). }\end{array}$ & $16 \%$ & $20 \%$ & $25 \%$ & \multirow[t]{2}{*}{ vnahiwlim } \\
\hline & $\begin{array}{l}\text { HWVP Non-crystalline low-temperature } \\
\text { HLW/TRU waste glass maximum } \mathrm{Na}_{2} \mathrm{O} \\
\text { concentration limit (Orme 1995). }\end{array}$ & $10 \%$ & $12.5 \%$ & $16 \%$ & \\
\hline
\end{tabular}


WHC-SD-WM-ES-368

Revision 0

Table A-10. Immobilized Waste Volume Input Variables. (2 Sheets)

\begin{tabular}{|c|c|c|c|c|c|}
\hline \multirow[b]{2}{*}{$\begin{array}{l}\text { Technical } \\
\text { uncertainties }\end{array}$} & \multirow[b]{2}{*}{ Description } & \multicolumn{3}{|c|}{$\begin{array}{l}\text { Range of solution for technical } \\
\text { uncertainty }\end{array}$} & \multirow[b]{2}{*}{$\begin{array}{l}\text { Spreadsheet } \\
\text { variable name }\end{array}$} \\
\hline & & $\begin{array}{l}\text { Low- } \\
\text { range } \\
\text { value }\end{array}$ & $\begin{array}{l}\text { Mid-range } \\
\text { value }\end{array}$ & $\begin{array}{l}\text { High- } \\
\text { range } \\
\text { value }\end{array}$ & \\
\hline \multirow{2}{*}{$\begin{array}{l}\text { NiO Maximum } \\
\text { immobilized } \\
\text { HLW/TRU waste } \\
\text { concentration limit }\end{array}$} & $\begin{array}{l}\text { Crystalline HLW/TRU waste form } \\
\text { maximum NiO concentration limit } \\
\text { (Glass Chemistry Workshop 1995). }\end{array}$ & $2 \%$ & $6 \%$ & $10 \%$ & \multirow[t]{2}{*}{ vrithwlim } \\
\hline & $\begin{array}{l}\text { Non-crystatline low-temperature } \\
\text { HLW/TRU waste glass maximum NiO } \\
\text { concentration limit (Glass Chemistry } \\
\text { Workshop 1995). }\end{array}$ & $1 \%$ & $2 \%$ & $3 \%$ & \\
\hline \multirow{2}{*}{$\begin{array}{l}\mathrm{ZrO}_{2} \text { Maximum } \\
\text { immobilized } \\
\text { HLW/TRU waste } \\
\text { concentration limit }\end{array}$} & $\begin{array}{l}\text { Crystalline } \mathrm{HLW} / \mathrm{TRU} \text { waste form } \\
\text { maximum } \mathrm{ZrO}_{2} \text { concentration limit } \\
\text { (Glass Chemistry Workshop 1995). }\end{array}$ & $10 \%$ & $20 \%$ & $30 \%$ & \multirow[t]{2}{*}{ varhlwwlim } \\
\hline & $\begin{array}{l}\text { HWVP Non-crystalline low-temperature } \\
\text { HLW/TRU waste glass maximum } \mathrm{ZrO}_{2} \\
\text { concentration limit (Orme 1995). }\end{array}$ & $9 \%$ & $10 \%$ & $11 \%$ & \\
\hline $\begin{array}{l}\text { Double-shell tank } \\
\text { heel }\end{array}$ & $\begin{array}{l}\text { Percentage of waste left behind is DSTs } \\
\text { after sluicing }\end{array}$ & ${ }^{*} 0 \%$ & $10 \%$ & $15 \%$ & dstheel \\
\hline $\begin{array}{l}\text { Single-shell tank } \\
\text { heel }\end{array}$ & $\begin{array}{l}\text { Percentage of waste left behind by the } \\
\text { primary sluicer and secondary } \\
\text { mechanical arm retrieval system. }\end{array}$ & $0 \%$ & $0.001 \%$ & $0.05 \%$ & sstheel \\
\hline
\end{tabular}

*Indicates a modification of variables reported in McConville and Johnson (1995).

anly the maximum concentration limits with a significant effect on cost, duration or volume are shown (see Figures A-1 through A-21). See WHC-EP-0874, Appendix D (McConville and Johnson 1995) for a complete listing of maximum concentration limits for immobilized HLW/TRU waste.

Shaded cells indicates "Base Case" values. 
WHC-SD-WM-ES-368

Revision 0

\section{A4.0 METHODS FOR EVALUATION}

The evaluation of the decision criteria for each of the four cases is conducted in two steps: (1) deterministic sensitivity analysis, and (2) probabilistic analysis. The INSIGHT Model communicates with a decision analysis software, Supertree ${ }^{1}$, to perform both analyses.

The deterministic sensitivity analysis is performed first to identify which input variable uncertainties have the most significant effect on the performance measure being evaluated. The result is a bar chart, known as a tornado chart, that ranks the input variables in descending order according to their influence on the performance measure calculation. Each. of the significant input variables are assigned probabilities to the high, mid, and low values of their uncertainty ranges. The performance measure is calculated for all possible combinations of the significant variable ranges and assigned probabilities. The result is a cumulative probability distribution over the full range of a performance measure.

\section{A4.1 DETERMINISTIC SENSITIVITY ANALYSIS}

The INSIGHT Model communicates with the decision analysis software, Supertree ${ }^{8}$, to perform the deterministic sensitivity analysis. Supertree calculates the deterministic sensitivity of input variable uncertainties with respect to a performance measure in four successive steps:

1. A base case value is selected from the range of each input uncertainty and the resulting performance measure is calculated. This base case performance measure value is only one possible combination of the many possible from the input variables. The base case value shown in the lower right corner of the tornado charts is the value calculated by the INSIGHT Model with all variables set to their base case values. All base case values included in the INSIGHT Model are listed in Section A3.0, Tables A-8 through A-10, and are indicated by a shaded cell.

2. An input variable is selected for evaluation.

a. The value of the input variable is changed from its base case value to its high value, leaving all the other input variables in the INSIGHT Model at their base case values.

b. The performance measure is calculated for the set of inputs described in (a).

${ }^{1}$ Supertree is a registered trademark of Strategic Decisions Group. 
c. The value of the selected input variable is then changed to its low value, leaving all the other input variables at their base case values.

d. The performance measure is calculated for the set of inputs described in (c).

e. The swing around the base case value of the performance measure is recorded.

f. All input variables are then reset to their base case values.

3. Another input variable is chosen for evaluation and the procedure in Step 2 is repeated until all input variables have been evaluated. Approximately 100 input . variables are included in the INSIGHT Model and are evaluated for each deterministic sensitivity analysis.

4. The input variables are ranked in descending order on a bar chart according to their influence on the performance measure calculation.

The product of the deterministic sensitivity analysis is a tornado chart. The tornado chart is a bar chart that is wide at the top and narrow at the bottom, suggesting the form of a tornado. Hence, its informal name "tornado chart" is often used. The input variables that significantly affect the calculation of a performance measure are those at the top of the tornado chart. Only the most significant variables are used in the subsequent probabilistic analysis. The deterministic sensitivity analysis step simplifies the probabilistic analysis by eliminating those variables having little or no effect on the calculation of the performance measures.

\section{A4.2 PROBABMISTIC ANALYSIS}

The probabilistic analysis is also performed by linking the decision analysis software, Supertree ${ }^{\circledast}$, to the INSIGHT Model. Each of the significant input variables identified by inspection of the tornado chart are assigned probabilities over the range of their possible values. For this report, the low and high values for each of the significant variables identified in the deterministic sensitivity analysis were assigned a probability of 0.25 , whereas the nominal value for each significant variable was assigned a probability of 0.5 .

The INSIGHT Model, in conjunction with the Supertree ${ }^{\$}$ software is used to calculate a probabilistic distribution for a specified performance measure and waste treatment strategy. A decision tree is constructed using the Supertree ${ }^{\$}$ software to relate each of the variables according to their influence on a performance measure. The Supertree ${ }^{\infty}$ software executes a series of commands that calculate the performance measure for each of the paths in the decision tree using the INSIGHT Model. The performance measure is calculated for all possible combinations of the significant variable ranges and assigned probabilities. The result is a cumulative probability distribution over the full range of the performance measure. 
WHC-SD-WM-ES-368

Revision 0

\section{A5.0 CASE STUDY RESULTS}

This section presents the deterministic and probabilistic results of the four case study evaluations for five of the six decision criteria: (1) total life-cycle cost, (2) life-cycle cost excluding disposal costs, (3) process duration, (4) volume of immobilized HLW produced, and (5) volume of immobilized TRU waste produced. The criterion, "volume and radioactivity of immobilized LAW produced," was determined to be the same for all cases and, therefore, was not included in the deterministic and probabilistic evaluations. The evaluations were performed using the algorithms discussed in Section A2.0, the associated variable uncertainty ranges listed in Section A3.0 and the evaluation method described in Section A4.0.

\section{A5.1 LIFE-CYCLE COST INCLUDING DISPOSAL}

The results of the life-cycle cost including disposal cost deterministic sensitivity and probabilistic analyses for the four case studies are shown in Figures A-1 through A-5. The life-cycle cost is determined as net present worth in 1995 dollars and includes only the HLW/TRU waste treatment elements of the TWRS Program (see Tables A-3, A-4, and A-5). The DST retrieval operating cost is included in the HLW/TRU waste life-cycle cost since DST retrieval operations continue throughout the HLW/TRU waste process duration. Costs for SST retrieval, pretreatment, and LAW processing remain the same for all four cases, and, therefore, are not included in the life-cycle cost evaluation.

The tornado charts resulting from the deterministic sensitivity analyses (Figures A-1 through A-4) indicate the sodium oxide and chromium oxide concentration limits in the immobilized waste form, aluminum separation efficiency, and facility construction cost are areas of great uncertainty for all four case studies. The uncertainty ranges for each of these variables are listed in Table A-8. A comparison of the "base case life-cycle cost" values shown on Figures A-1 through A-4, indicates only a slight variation among the case studies. The INSIGHT Model calculates a "base case life-cycle cost" of approximately $\$ 8.5$ billion (1995 dollars) for all four cases.

Figure A-5 shows the cumulative probability distributions resulting from the probabilistic evaluation of the top five input variables of each tornado chart. The cumulative probability distribution curves confirm the tornado chart interpretation that the variations in life-cycle cost among the four case studies are negligible. Figure A-5 also indicates the HLW/TRU waste life-cycle cost including disposal could actually range from $\$ 7$ billion (1995 dollars) to $\$ 11$ billion (1995 dollars). The "base case life-cycle cost" of $\$ 8.5$ billion (1995 dollars) represents a cumulative probability of only 20 to 30 percent for the four case studies. At 80 percent cumulative probability, the life-cycle cost is approximately $\$ 10$ billion (1995 dollars) or less for all four cases. 
Figure A-1. Case 1 Life-Cycle Cost Tornado Chart.

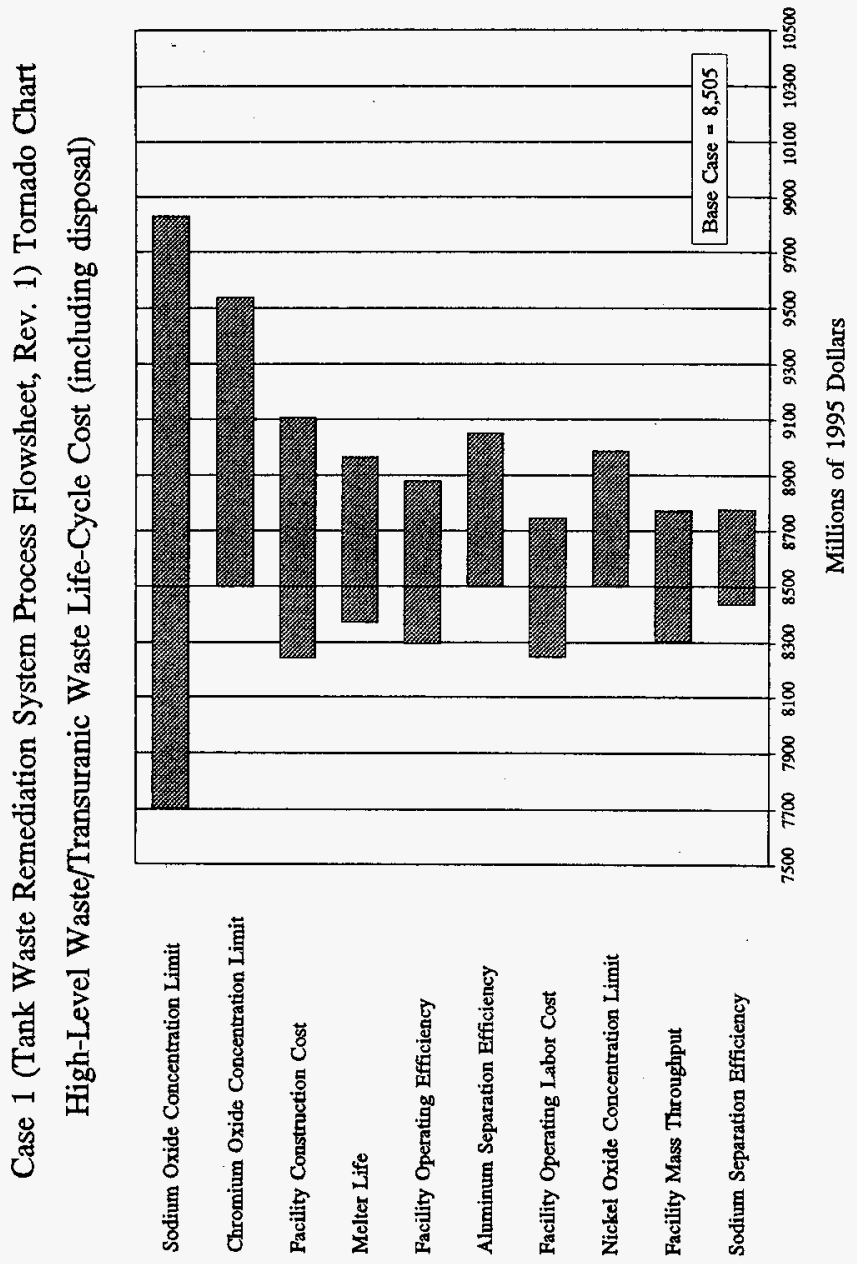


WHC-SD-WM-ES-368

Revision 0

Figure A-2. Case 2a Life-Cycle Cost Tornado Chart.

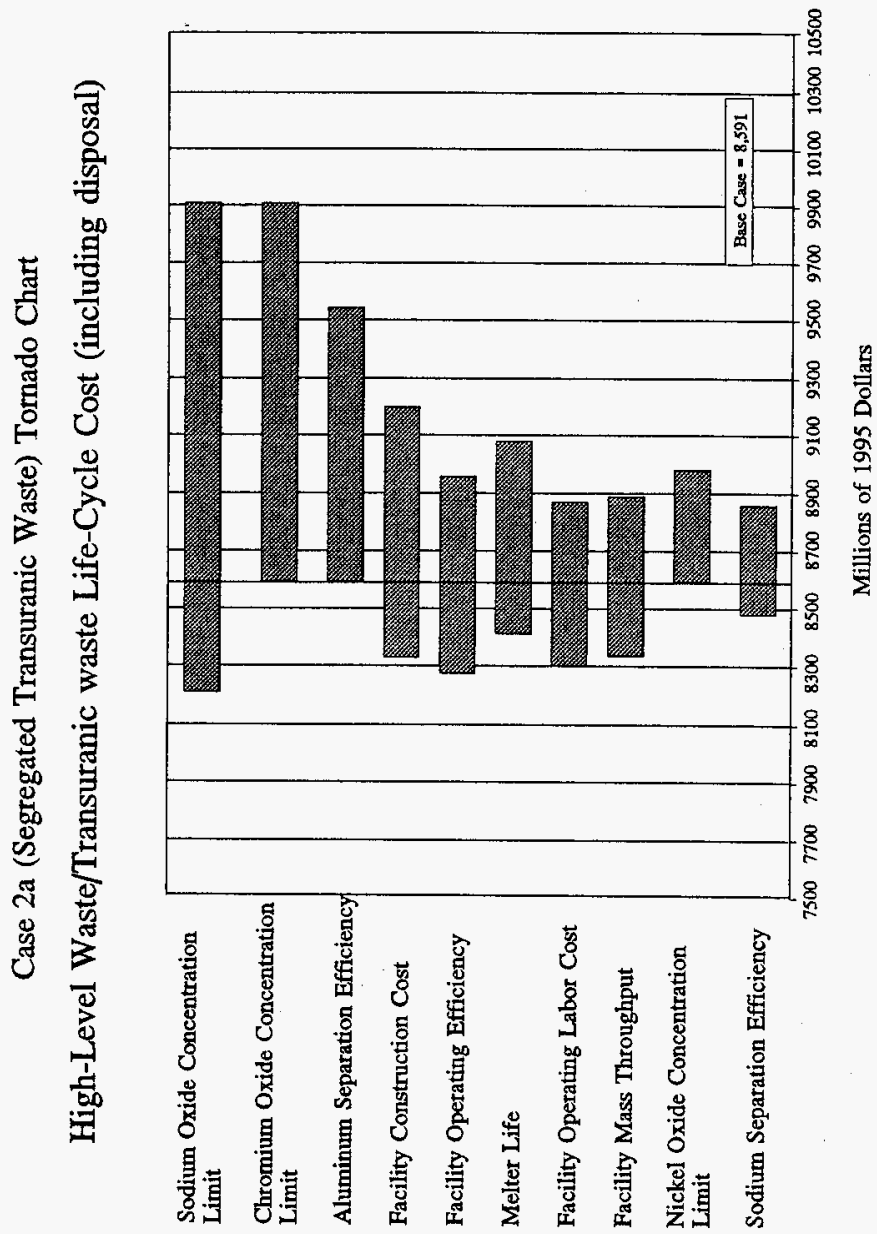


Figure A-3. Case 2b Life-Cycle Cost Tornado Chart.

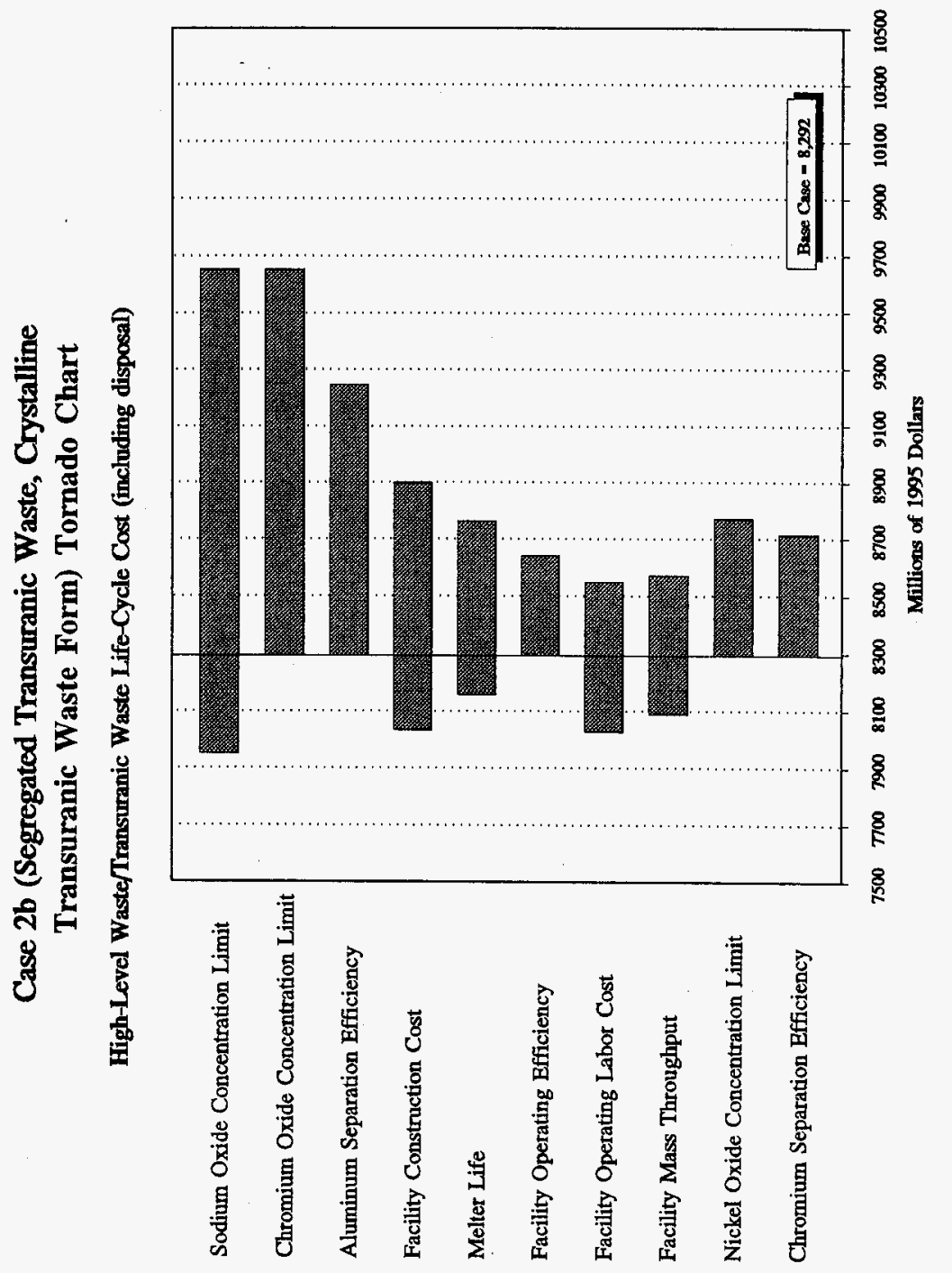




\section{Case 2c (Segregated Transuranic Waste, 10.7 MT/day Melter) Tornado Chart}

High-Level Waste/Transuranic Waste Life-Cycle Cost (including disposal)

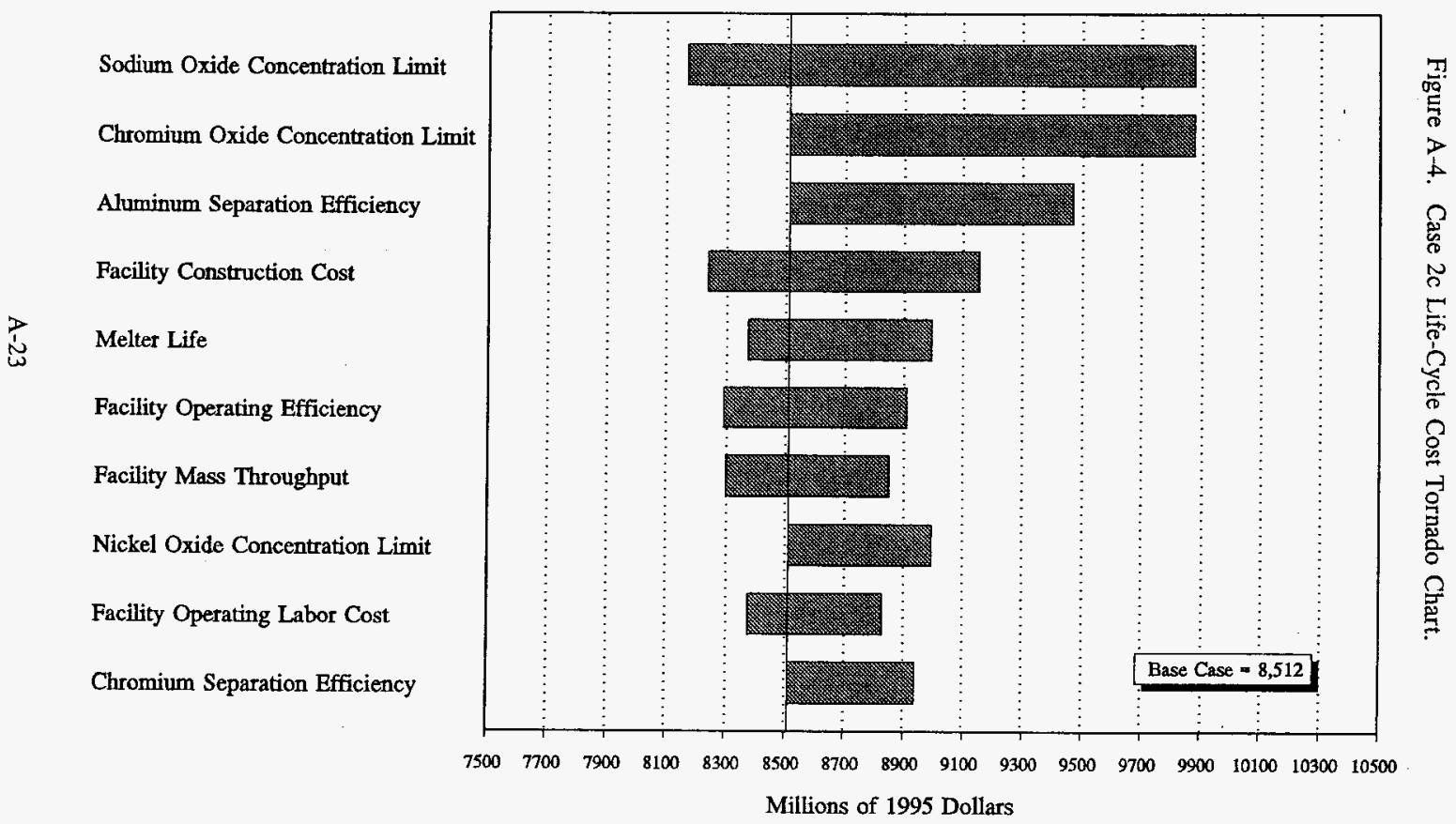


Figure A-5. Cases 1, 2a, 2b, 2c Life-Cycle Cost Probability Distributions.
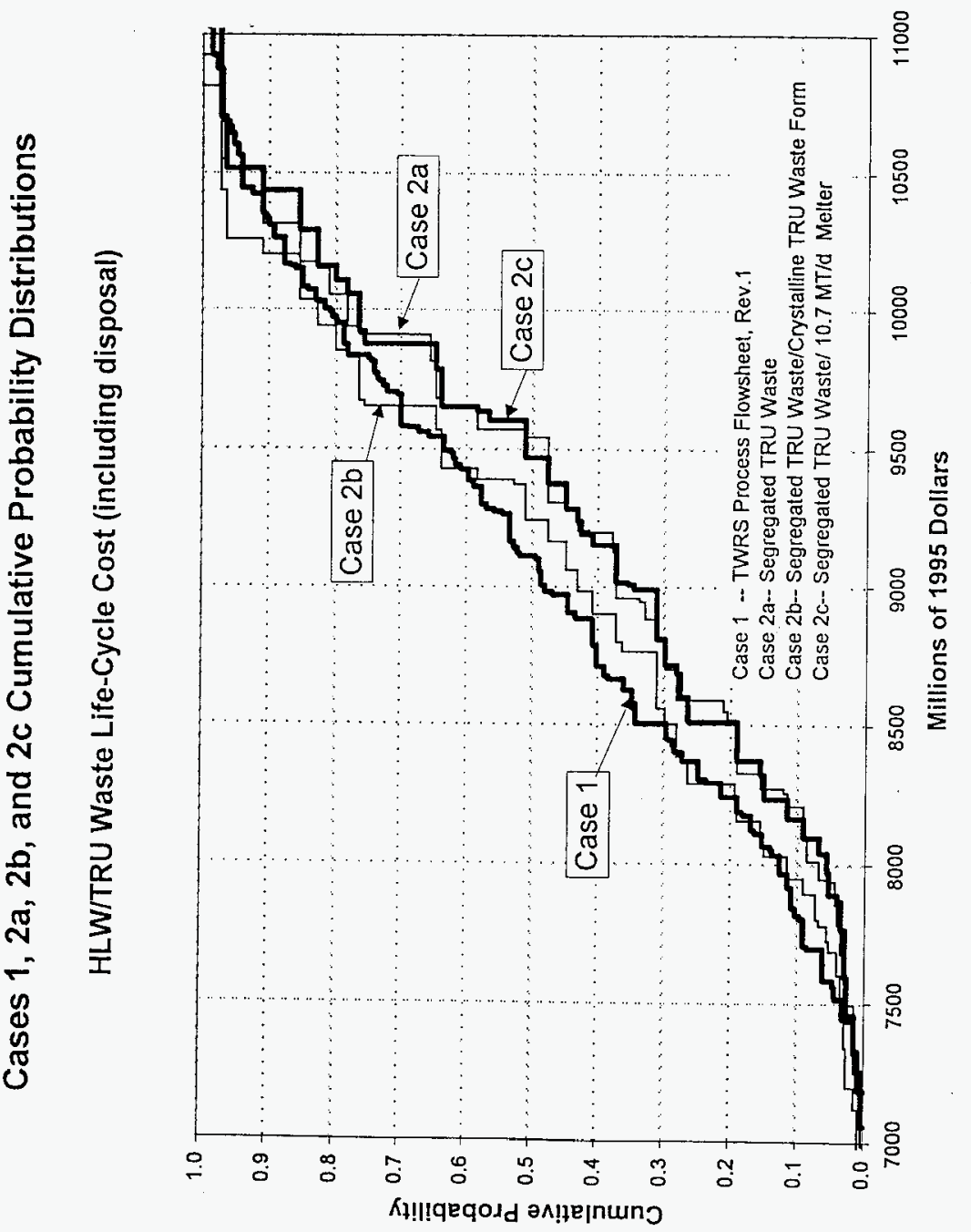
WHC-SD-WM-ES-368

Revision 0

\section{A5.2 LIFE-CYCLE COST EXCLUDING DISPOSAL COST}

The results of the life-cycle cost, excluding disposal cost, deterministic sensitivity and probabilistic analyses for the four case studies are shown in Figures A-6 through A-10. The life-cycle cost excluding disposal cost is determined as net present worth in 1995 dollars. The life-cycle cost excluding disposal cost includes only the HLW/TRU waste treatment elements of the TWRS Program but excludes costs for disposing of HLW and TRU waste (see Tables A-3, A-4, and A-5). The DST retrieval operating cost is included in the HLW/TRU waste life-cycle cost since DST retrieval operations continue throughout the HLW/TRU waste process duration. Costs for SST retrieval, pretreatment, and LAW processing remain the same for all four cases and, therefore, are not included in the lifecycle cost evaluation.

The tornado charts resulting from the deterministic sensitivity analyses (Figures A-6 through A-9) indicate the sodium oxide and chromium oxide concentration limits in the immobilized waste form, facility construction cost, melter life, and facility operating efficiency are areas of great uncertainty for all four case studies. The uncertainty ranges for each of these variables are listed in Table A-8. A comparison of the "base case life-cycle cost excluding disposal cost" values shown on Figures A-6 through A-9, indicates only a slight variation among the case studies. The INSIGHT Model calculates a "base case lifecycle cost excluding disposal cost" of approximately $\$ 6$ billion (1995 dollars) for all four cases.

Figure A-10 shows the cumulative probability distributions resulting from the probabilistic evaluation of the top five input variables of each life-cycle cost excluding disposal cost tornado chart (Figures A-6 through A-9). The cumulative probability distribution curves for life-cycle cost excluding disposal costs show that cost differences between Cases 1 and $2 b$ are negligible, and cost differences between Cases $2 \mathrm{a}$ and $2 \mathrm{c}$ are negligible. The chart also shows a constant variation between the two groups (i.e., Cases 1 and $2 b$ compared to Cases $2 a$ and $2 c$ ), with Cases 1 and $2 b$ always costing less than Cases $2 a$ and $2 \mathrm{c}$. When compared to the cumulative probability distribution curves for life-cycle cost including disposal costs (Figure A-5), it can be seen that the uncertainties associated with disposal costs cause the variations among the cases to become less distinctive.

Figure A-10 also indicates the HLW/TRU waste life-cycle cost excluding disposal could actually range from $\$ 5$ billion to $\$ 8$ billion for all four cases. The "base case lifecycle cost excluding disposal cost" of $\$ 6$ billion (1995 dollars) represents a cumulative probability of only 30 percent for Cases $2 a$ and $2 c$, and a cumulative probability of approximately 40 percent for cases 1 and $2 \mathrm{~b}$. At 80 percent cumulative probability, the lifecycle cost excluding disposal cost is approximately $\$ 6.7$ billion (1995 dollars) or less for Cases 1 and $2 b$, and $\$ 6.9$ billion (1995 dollars) or less for Cases $2 \mathrm{a}$ and $2 \mathrm{c}$. 
Revision 0

Figure A-6. Case 1 Life-Cycle Cost (Excluding Disposal) Tornado Chart.

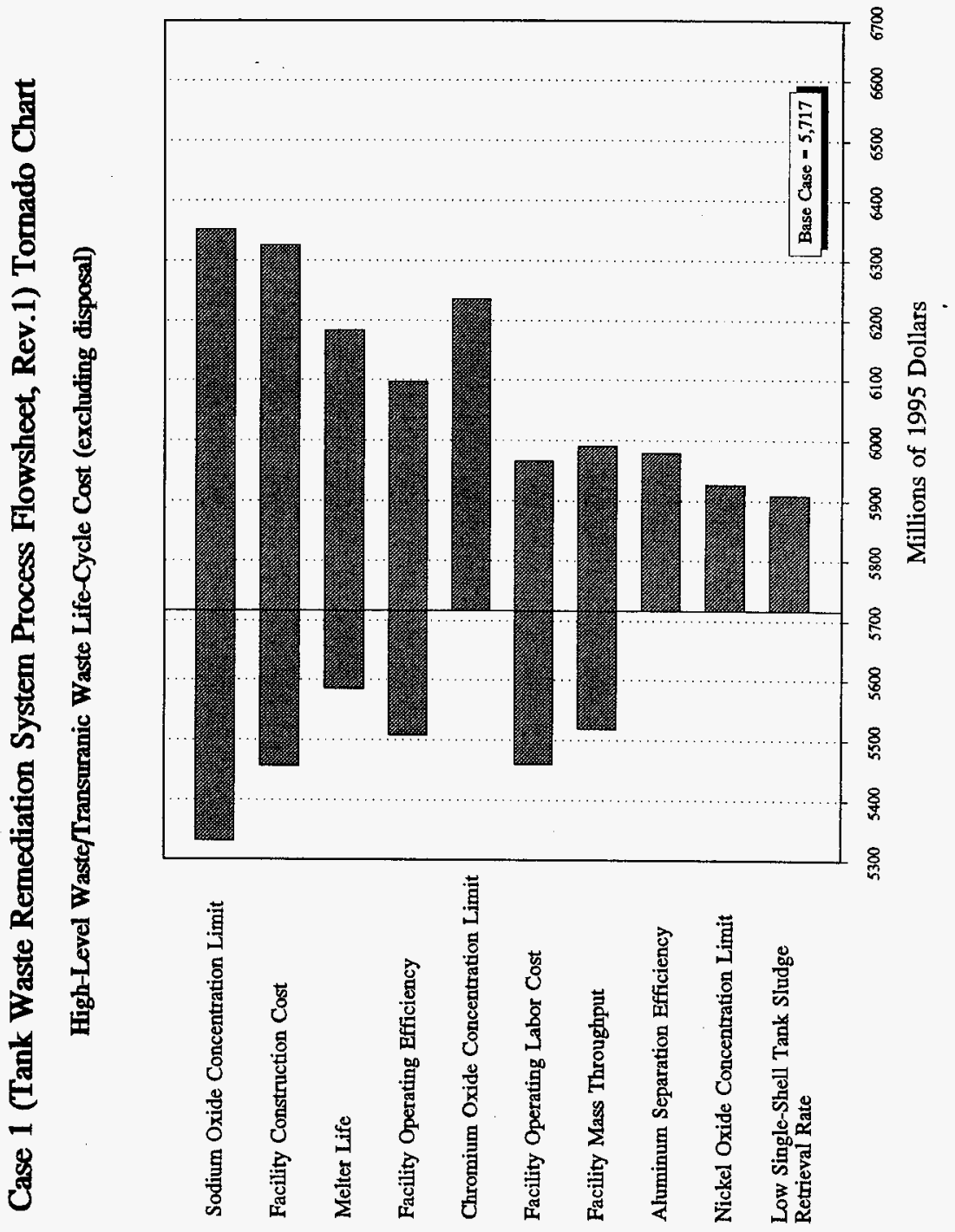


Figure A-7. Case 2a Life-Cycle Cost (Excluding Disposal) Tornado Chart.

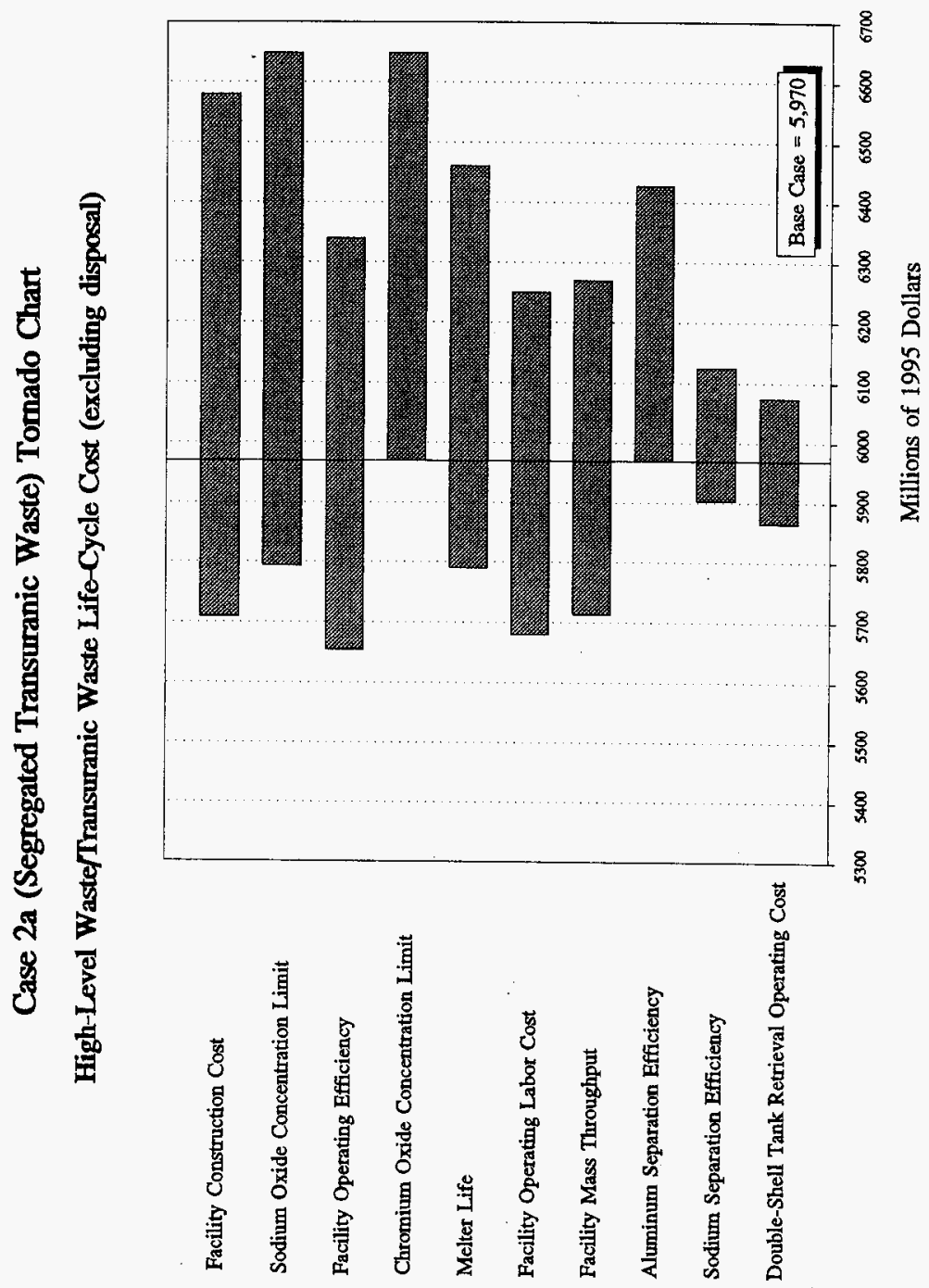


Case 2b (Segregated Transuranic Waste, Crystalline Transuranic Waste Form) Tornado Chart

High-Level Waste/Transuranic Waste Life-Cycle Cost (excluding disposal)

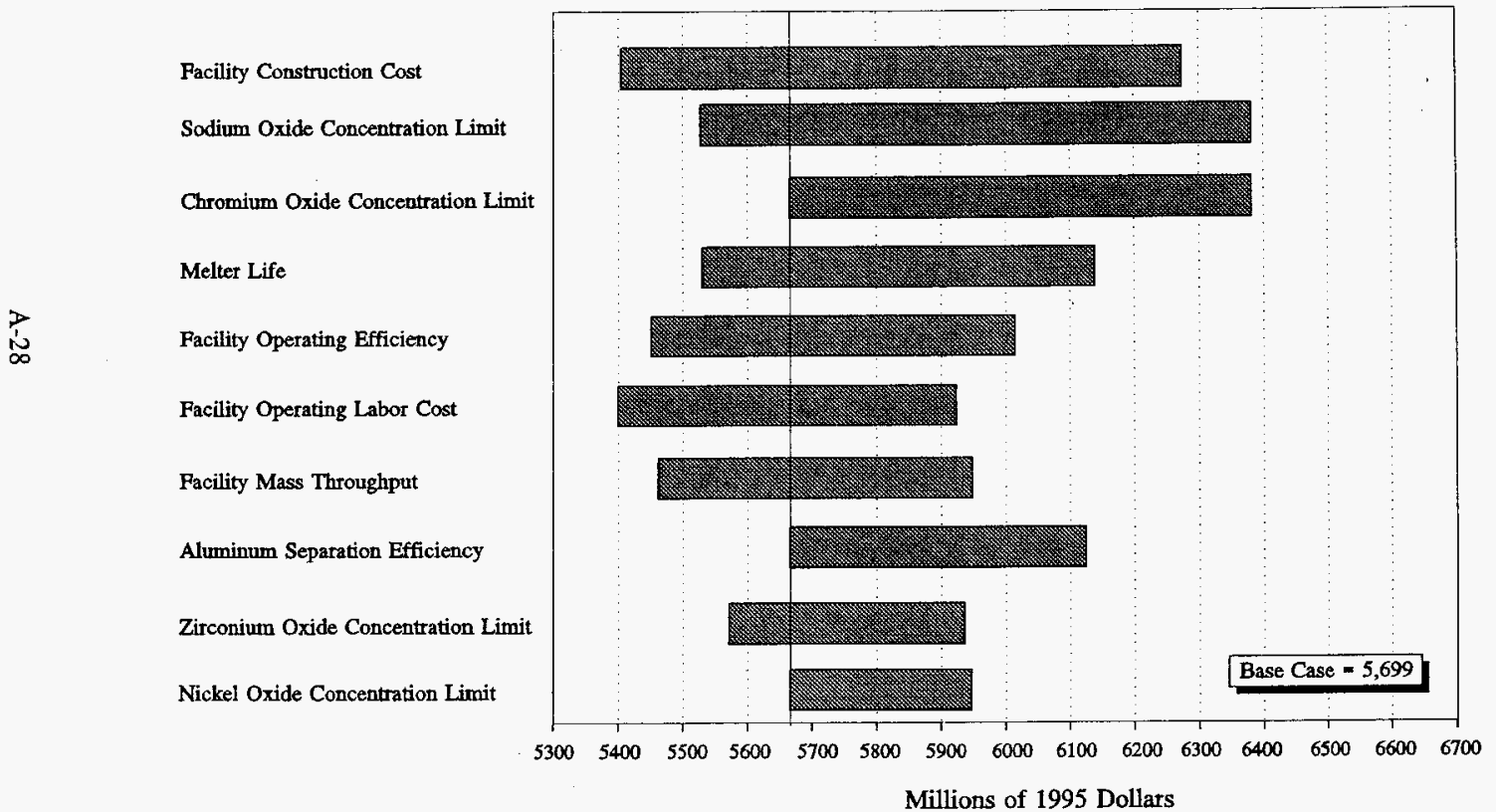

Millions of 1995 Dollars 
WHC-SD-WM-ES-368

Revision 0

Figure A-9. Case 2c Life-Cycle Cost (Excluding Disposal) Tornado Chart.

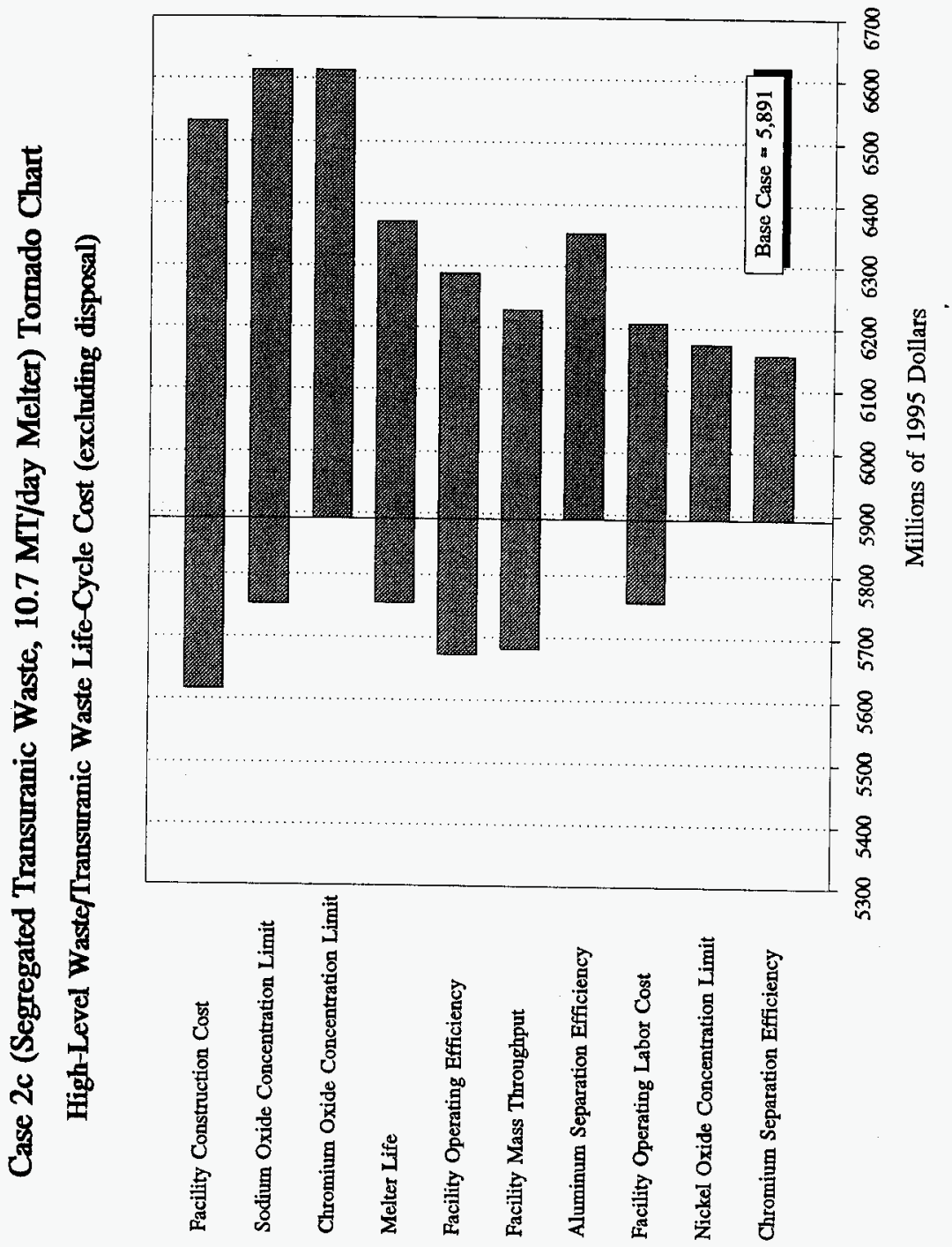


Cases 1, 2a, 2b, and 2c Cumulative Probability Distributions

HLW/TRU Waste Life-Cycle Cost (excluding disposal)

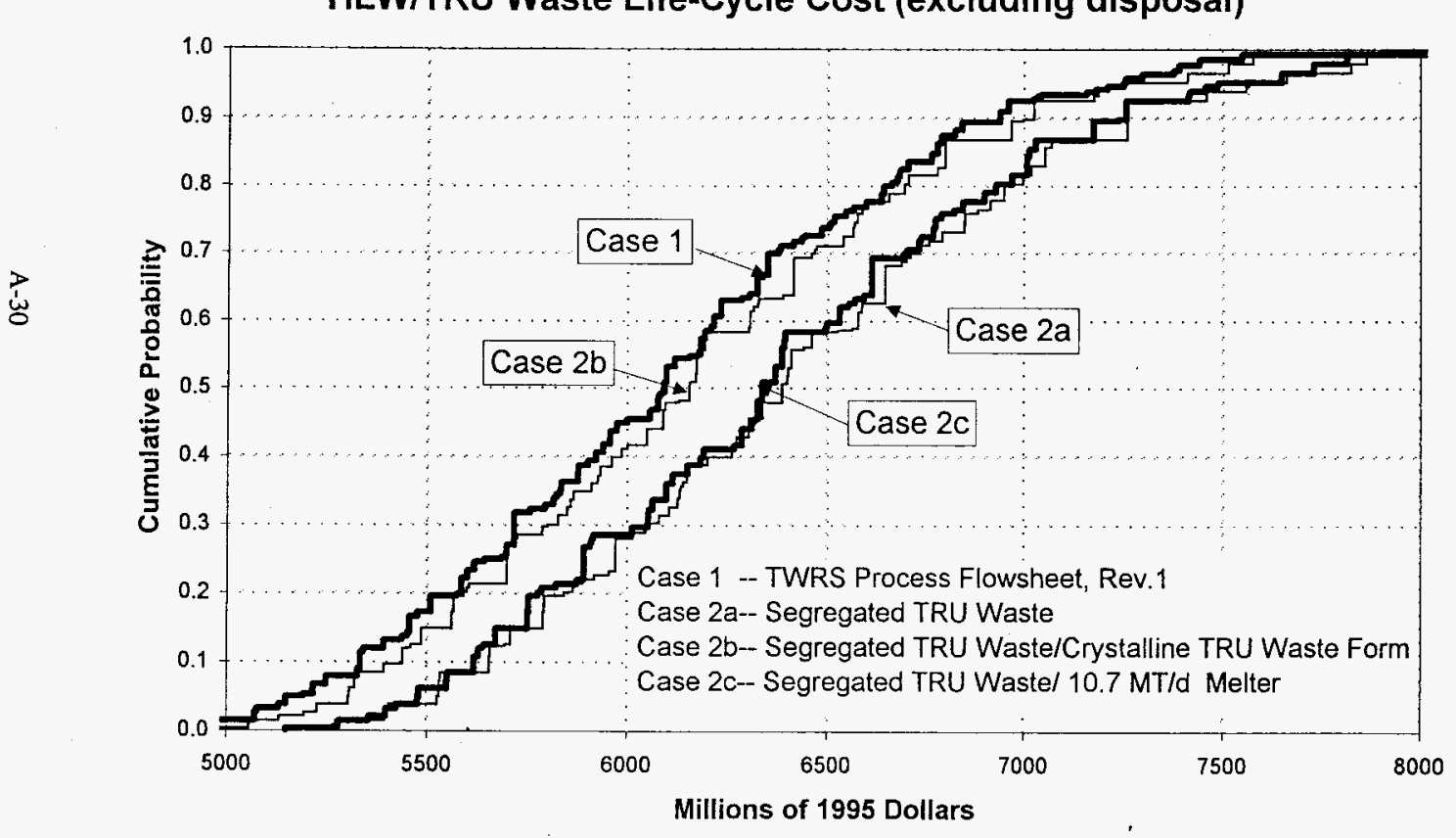


WHC-SD-WM-ES-368

Revision 0

\section{A5.3 PROCESS DURATION}

The results for the process duration deterministic sensitivity and probabilistic analyses for the four case studies are shown in Figures A-11 through A-15. The HLW/TRU waste process duration is determined as the time period (years) necessary to complete immobilization of the HLW and TRU tank wastes once tank waste retrieval has commenced (see Table A-6). The pretreatment and LAW process durations remain the same for all four cases and, therefore, are not included in the process duration evaluation.

The tornado charts resulting from the deterministic sensitivity analyses (Figures A-11 through 14) indicate that facility operating efficiency, facility mass throughput, melter life, sodium oxide and chromium oxide concentration limits in the immobilized waste form are areas of great uncertainty for all four case studies. The uncertainty ranges for each of these variables are listed in Table A-9. A comparison of the base case process duration values shown on Figures A-11 through A-15 indicates a variation of approximately three years among the case studies. The INSIGHT Model calculates a "base case process duration" of 13 years for Cases 1 and $2 c, 16$ years for Case 2a, and 14 years for Case $2 b$.

Figure A-15 shows the cumulative probability distributions resulting from the probabilistic evaluation of the top five input variables of each process duration tornado chart (Figures A-11 through A-14). Figure A-15 shows distinctive variations among the case studies. Cases 1 and $2 \mathrm{c}$ overlap and follow approximately the same curve. The two cases process the HLW and TRU waste in the shortest duration. The variation between Case $2 \mathrm{~b}$ and Cases 1 and $2 \mathrm{c}$ is distinct, but very small. Case $2 \mathrm{a}$ requires the longest process duration.

Figure A-15 indicates the HLW/TRU waste process duration could actually range from 8 to 26 years. Assuming the HLW/TRU waste process begins in 2009, the process duration must be 19 years or less to meet the Tri-Party Agreement mandated completion date of 2028 . The cumulative probability of meeting the Tri-Party Agreement completion date is approximately 90 percent for Cases 1 and $2 c, 80$ percent for Case $2 b$, and 75 percent for Case 2a.

The variation in process duration is expected since segregating the TRU waste from the HLW ultimately produces more immobilized waste, extending the process duration. The segregated TRU waste has a high zirconium concentration and the TRU waste volume is sensitive to the zirconium oxide concentration limit. Case $2 \mathrm{~b}$ produces a crystalline TRU waste form with a higher zirconium oxide concentration limit that reduces the immobilized TRU waste volume. Case $2 \mathrm{c}$ has a larger melter and canister handling capacity to accommodate the larger waste throughput in the same duration as Case 1 . 
WHC-SD-WM-ES-368

Revision 0

Figure A-11. Case 1 Process Duration Tornado Chart.

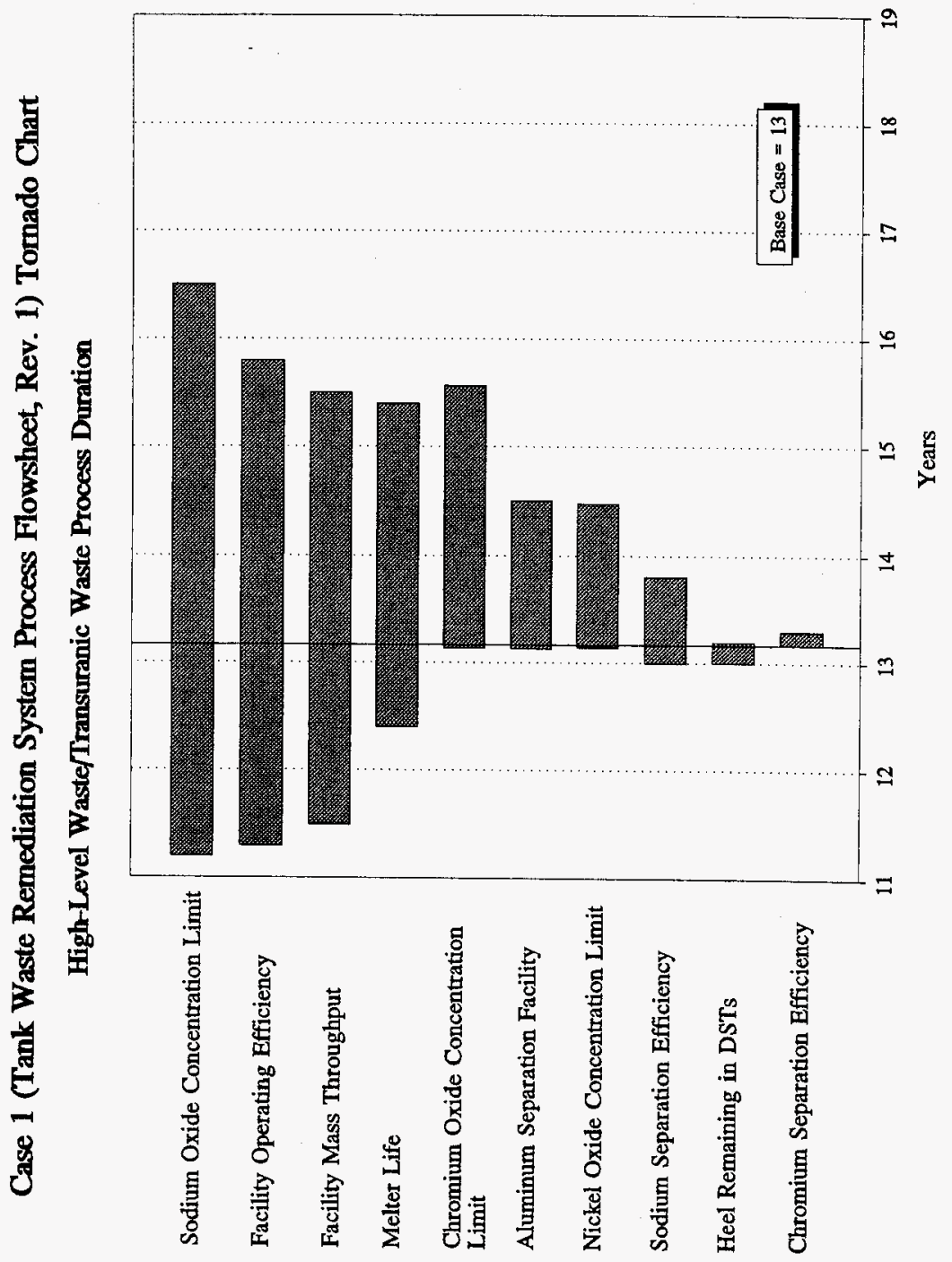




\section{Case 2a (Segregated Transuranic Waste) Tomado Chart}

\section{High-Level Waste/Transuranic Waste Process Duration}

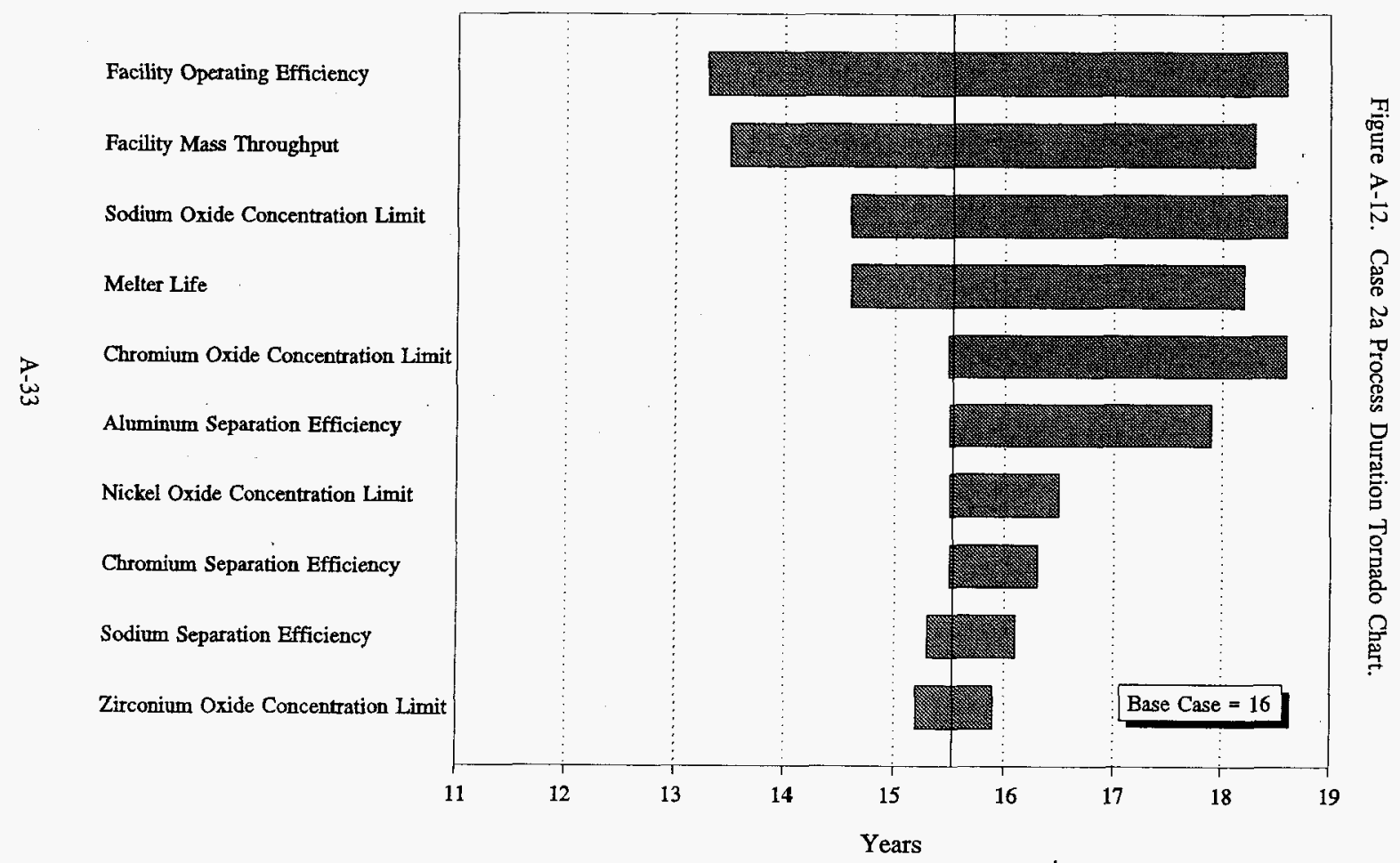


WHC-SD-WM-ES-368

Revision 0

Figure A-13. Case 2b Process Duration Tornado Chart.

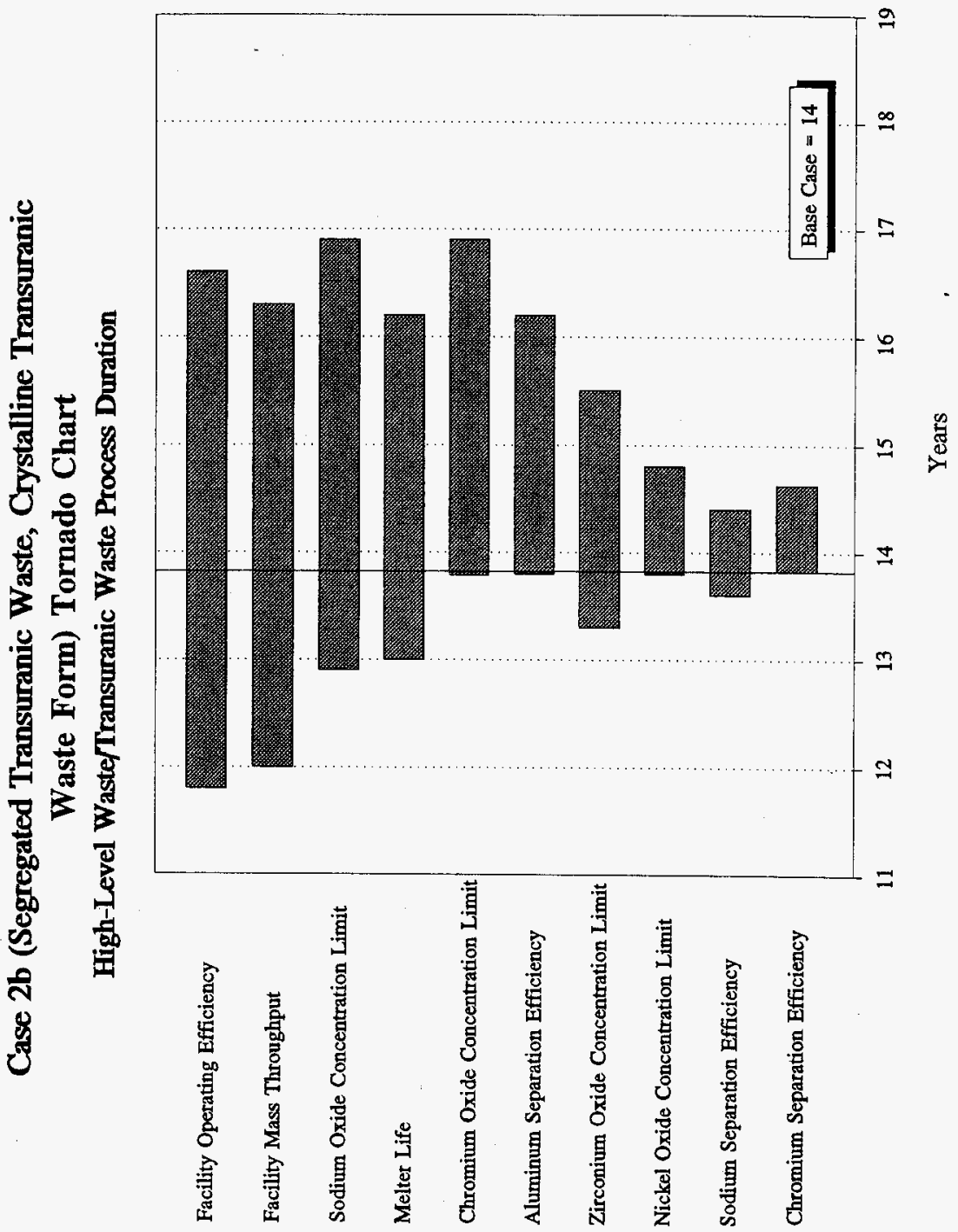




\section{Case 2b (Segregated Transuranic Waste, Crystalline Transuranic \\ Waste Form) Tornado Chart \\ High-Level Waste/Transuranic Waste Process Duration}

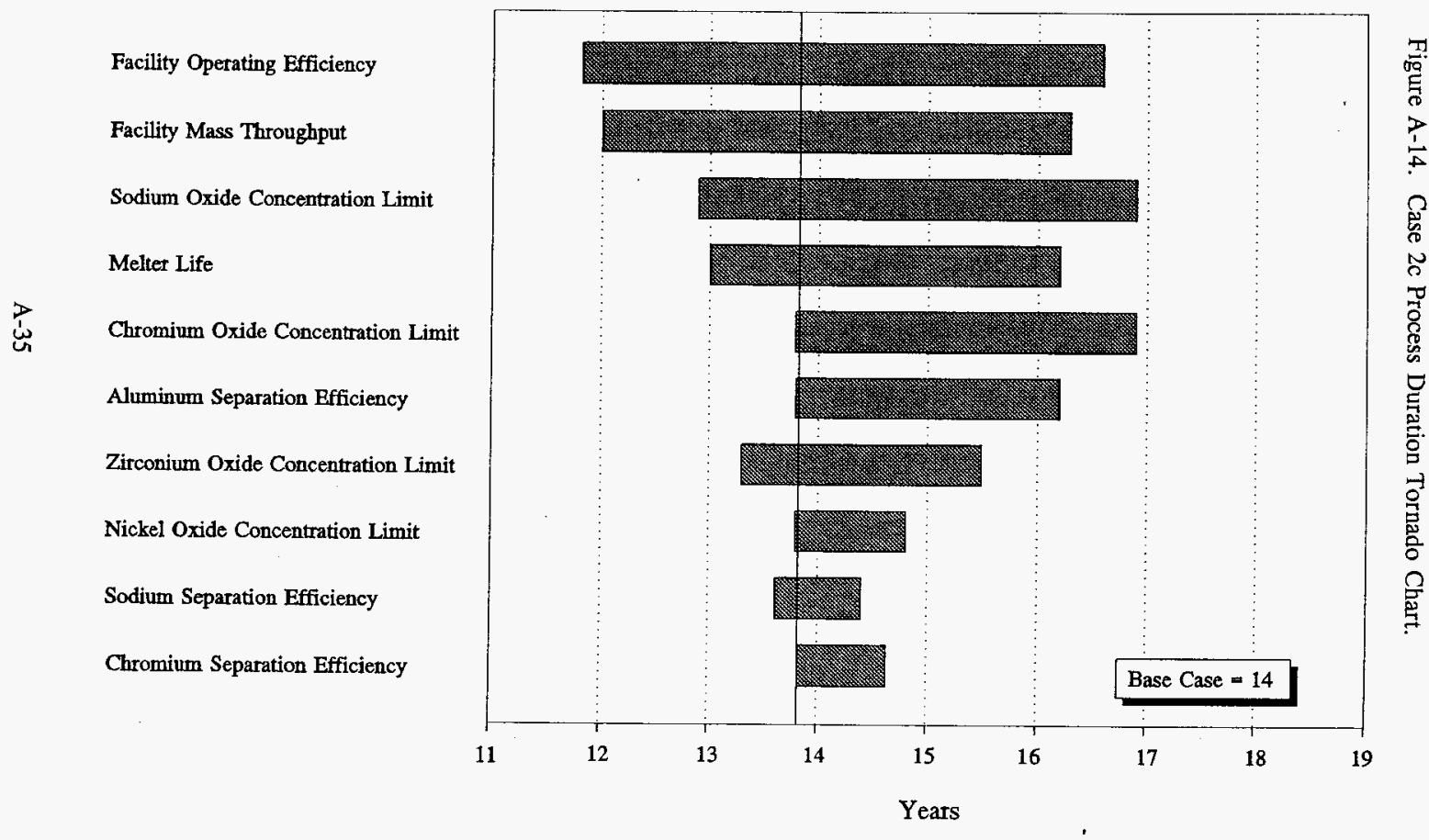


Cases 1, 2a, 2b, and 2c Cumulative Probability Distributions

\section{HLW/TRU Waste Process Duration}

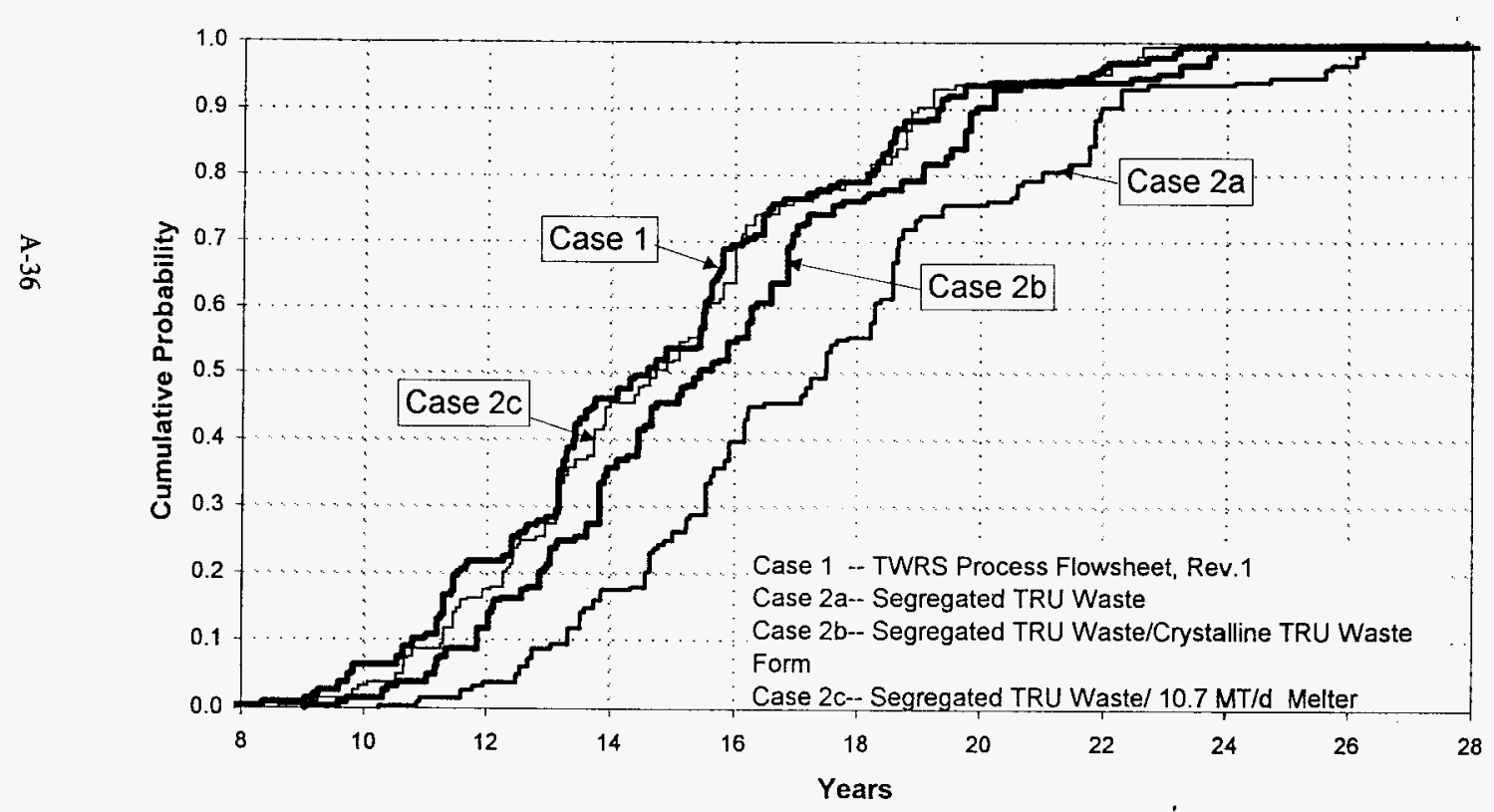


WHC-SD-WM-ES-368

Revision 0

\section{A5.4 VOLUME OF IMMOBILIZED HIGH-LEVEL WASTE PRODUCED}

The results of the immobilized HLW volume deterministic sensitivity and probabilistic analyses for the four case studies are shown in Figures A-16 through A-18. The immobilized HLW volume is determined as the number of $1.26 \mathrm{~m}^{3}$ containers produced for disposal in an offsite HLW repository (see Table A-7).

The tornado charts resulting from the deterministic sensitivity analyses (Figures A-16 and A-17) indicate the sodium oxide, chromium oxide, and nickel oxide concentration limits in the immobilized waste form, and the aluminum separation efficiency are areas of great uncertainty for all four case studies. The uncertainty ranges for each of these variables are listed in Table A-10. Figure A-16 shows the "base case" number of $1.26 \mathrm{~m}^{3} \mathrm{HLW}$ containers produced is approximately 7,100 for blended HLW and TRU waste (Case 1). Figure A-17 shows the "base case" number of $1.26 \mathrm{~m}^{3} \mathrm{HLW}$ containers is approximately 6,550 for the three segregated TRU waste Cases $2 a, 2 b$, and $2 c$.

Figure A-18 shows the cumulative probability distributions resulting from the probabilistic evaluation of the top five input variables of the two HLW volume tornado charts (Figures A-16 and A-17). The cumulative probability distribution curves for HLW volume indicate the number of $1.26 \mathrm{~m}^{3} \mathrm{HLW}$ containers produced could range from approximately 5,700 to 11,700 containers for blended HLW and TRU waste, and from 5,100 to 9,300 containers for segregated HLW and TRU waste. The segregated cases always produce fewer HLW canisters than the blended case. However, it is important to keep in mind the overall volume of immobilized HLW and TRU waste produced. 
WHC-SD-WM-ES-368

Revision 0

Figure A-16. Case 1 High-Level Waste Volume Tornado Chart.

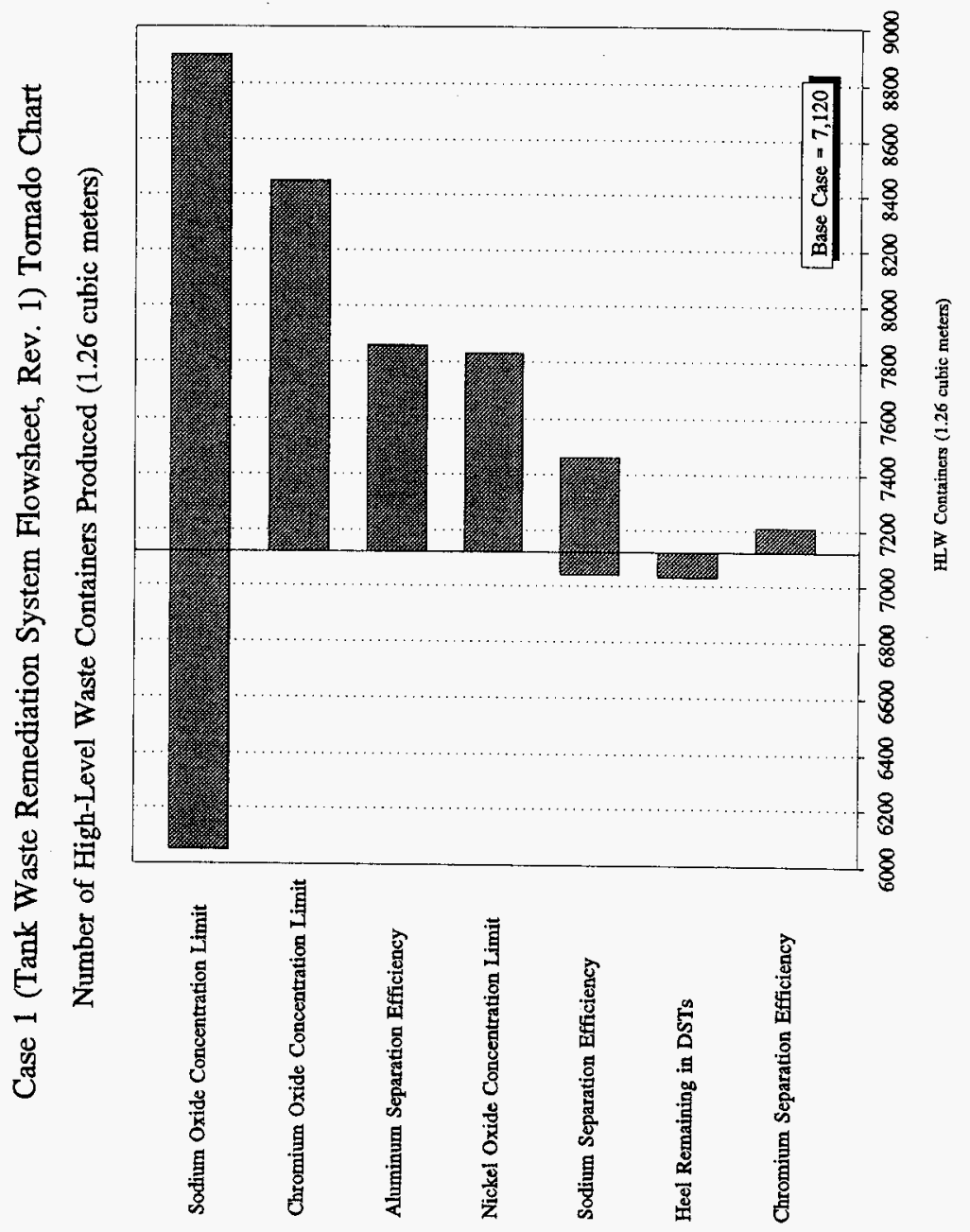


WHC-SD-WM-ES-368

Revision 0

Figure A-17. Cases 2a, 2b, 2c High-Level Waste Volume Tornado Chart.

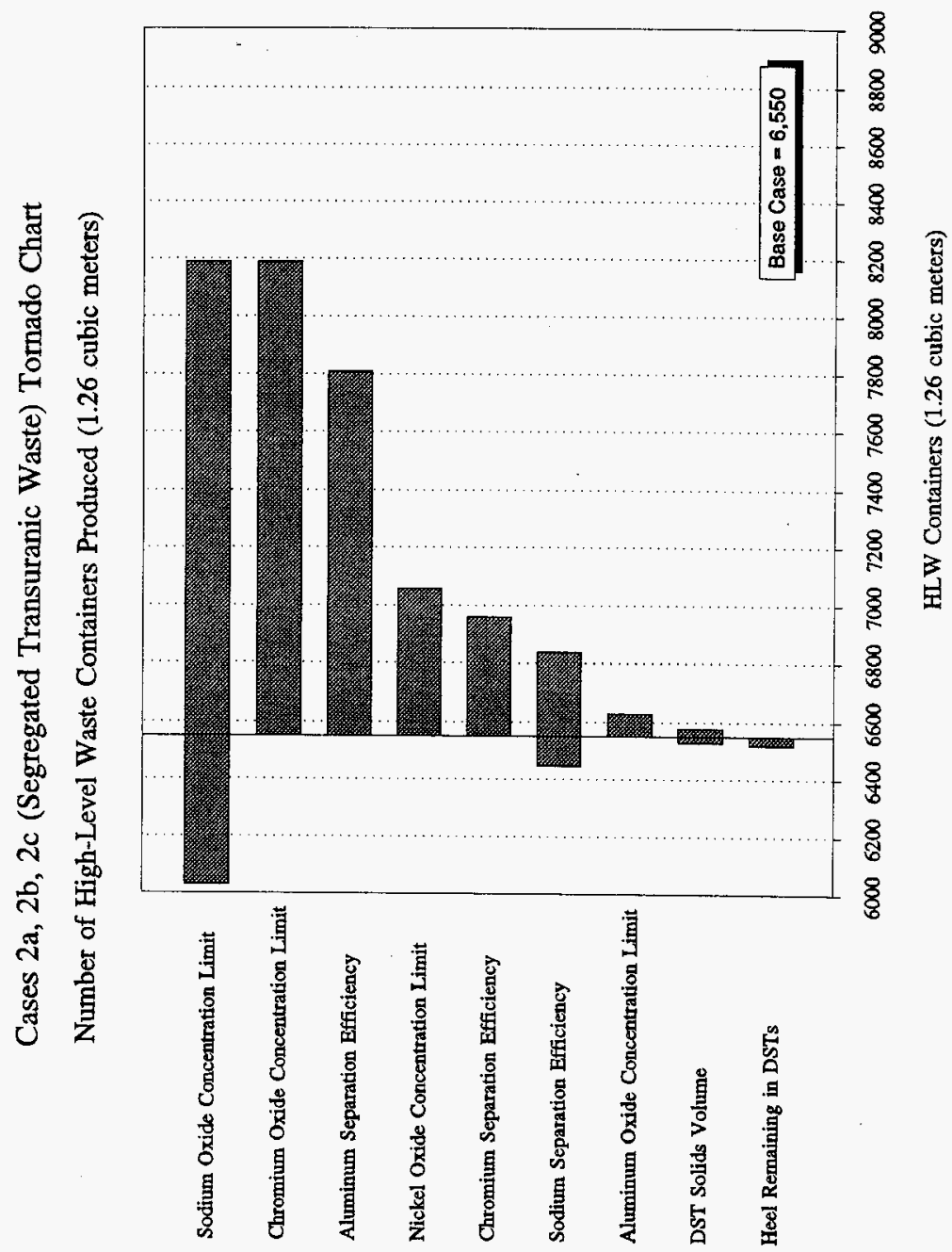


Cases 1, 2a, 2b, and 2c Cumulative Probability Distributions

\section{Number of HLW Containers Produced $(1.26 \mathrm{~m} 3)$}

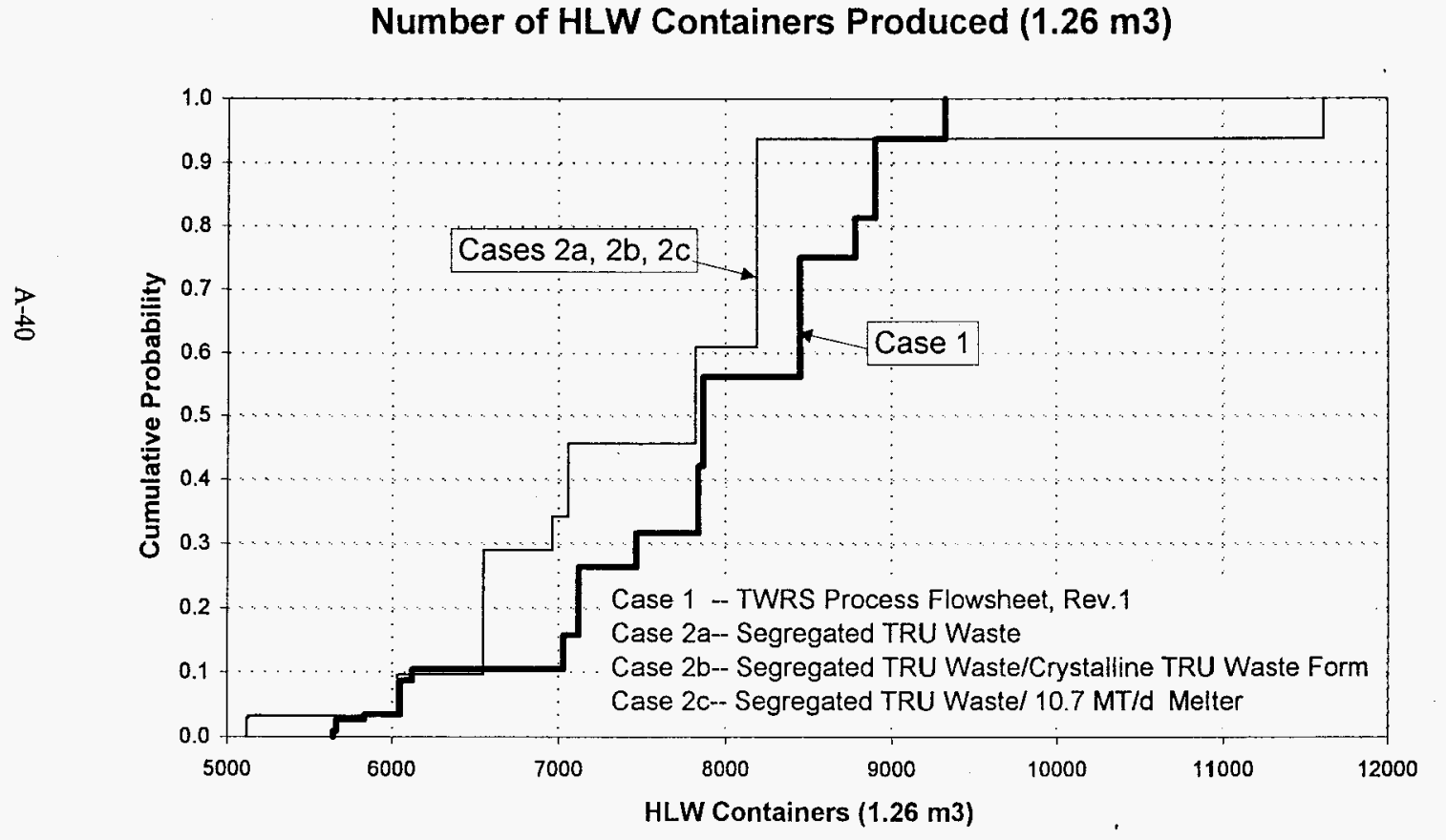


WHC-SD-WM-ES-368

Revision 0

\section{A5.5 VOLUME OF IMMOBLIZED TRANSURANIC WASTE PRODUCED}

The results of the immobilized TRU waste volume deterministic sensitivity and probabilistic analyses for the three segregated TRU waste case studies $(2 \mathrm{a}, 2 \mathrm{~b}, 2 \mathrm{c})$ are shown in Figures A-19 through A-21. The immobilized TRU waste volume is determined as the number of $0.71 \mathrm{~m}^{3}$ containers produced for disposal at WIPP (see Table A-7).

The tornado charts resulting from the deterministic sensitivity analyses (Figures A-19 and 20) indicate the zirconium oxide concentration limit in the immobilized waste form, and the heel remaining in the DSTs are areas of great uncertainty for the three segregated TRU waste Cases $(2 a, 2 b, 2 c)$. The uncertainty ranges for each of these variables are listed in Table A-10. Figure A-19 shows the "base case" number of $0.71 \mathrm{~m}^{3}$ TRU waste containers . produced is approximately 1,850 for the non-crystalline glass cases ( $2 \mathrm{a}$ and $2 \mathrm{c}$ ). Figure A-20 shows the "base case" number of $0.71 \mathrm{~m}^{3}$ TRU waste containers is approximately 925 for Case $2 b$, crystalline TRU waste form.

Figure A-21 shows the cumulative probability distributions resulting from the probabilistic evaluation of the two input variables of the TRU waste volume tornado charts (Figures A-19 and A-20). The cumulative probability distribution curves for TRU waste volume indicate the number of $0.71 \mathrm{~m}^{3}$ TRU waste containers produced could range from approximately 1,400 to 2,050 containers for non-crystalline TRU glass (cases $2 \mathrm{a}, 2 \mathrm{c}$ ), and from approximately 520 to 1,850 containers for a crystalline TRU waste form (case $2 b$ ). Since the segregated TRU waste has a high zirconium concentration, the immobilized TRU waste volume is sensitive to the zirconium oxide concentration limit. Case $2 \mathrm{~b}$ produces a crystalline TRU waste form with a higher zirconium oxide concentration limit that reduces the immobilized TRU waste volume. 
Cases $2 \mathrm{a}$ and $2 \mathrm{c}$ Tomado Chart

(Segregated Transuranic Waste, Segregated Transuranic Waste with 10.7 MT/d Melter)

Number of Transuranic Waste Containers Produced ( 0.71 cubic meters)

惡

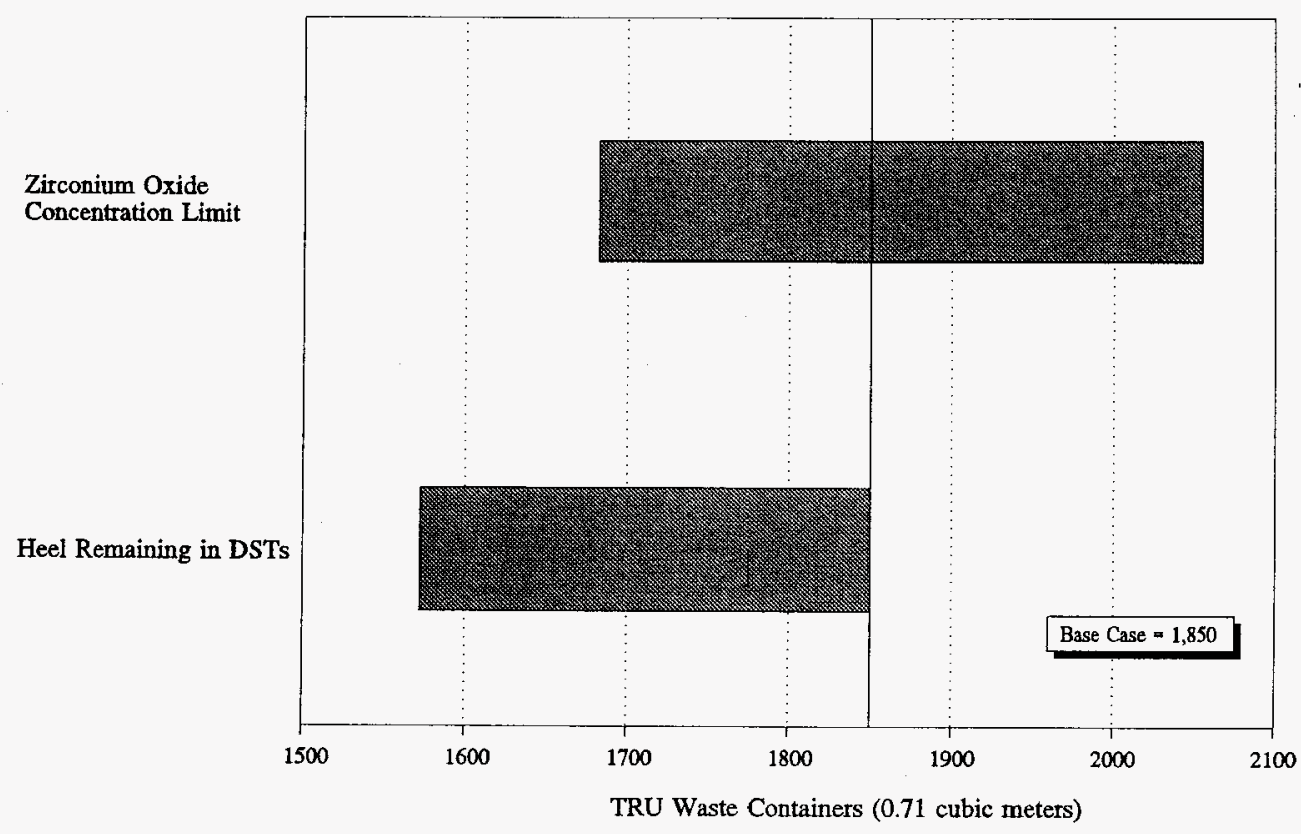




\section{Case 2b Tornado Chart}

(Segregated Transuranic Waste, Crystalline Transuranic Waste Form)

Number of Transuranic Waste Containers Produced ( 0.71 cubic meters)

\section{Zirconium Oxide}

Concentration Lmit

$\underset{1}{+}$

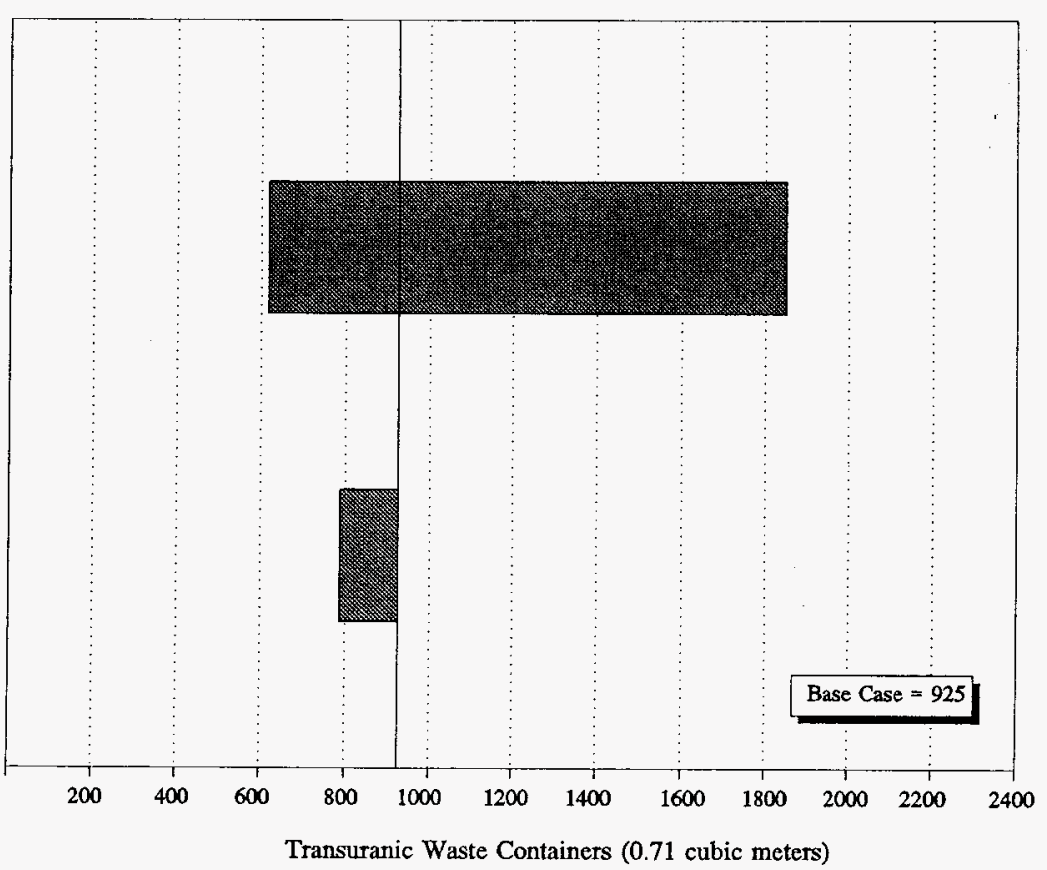

Heel Remaining in Double-Shell Tanks

Transuranic Waste Containers ( 0.71 cubic meters) 
Cases 2a, 2b, and $2 c$ Cumulative Probability Distributions

Number of TRU Waste Containers Produced $(0.71 \mathrm{~m} 3)$

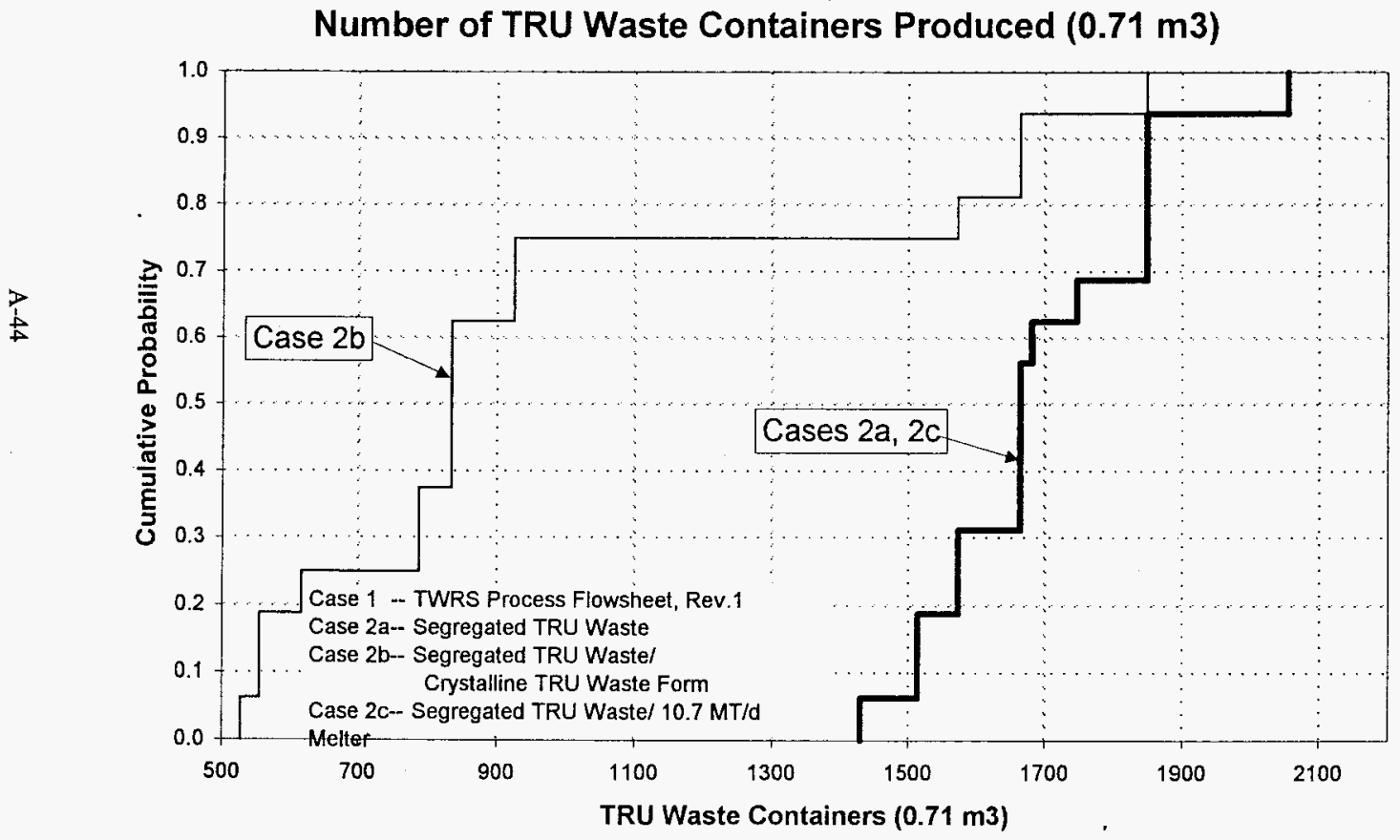


WHC-SD-WM-ES-368

Revision 0

\section{A6.0 REFERENCES}

DOE Order 5820.2A, Radioactive Waste Management, U.S. Department of EnergyHeadquarters, Washington, D.C.

Armacost, L. L., D. von Winterfeldt, J. Creighton, and M. Robershotte, 1994, Public Values Related to Decisions in the Tank Waste Remediation System Program, PNL-10107, Battelle Pacific Northwest Laboratory, Richland, Washington.

Bacon, R. F., 1996, Transmittal of Systems Requirements Review Action Plan to the U.S. Department of Energy, Richland Operations Office, 9650177, Letter to J. E. Kinzer dated January 15,1996, Westinghouse Hanford Company, Richland, Washington.

Boomer, K. D., S. K. Baker, A. L. Boldt, J. D. Galbraith, J. S. Garfield, C. E. Golberg, B. A. Higley, L. J. Johnson, M. J. Kupfer, R. M. Marusich, R. J. Parazin, A. N. Praga, G. W. Reddick, J. A. Reddick, E. J. Slaathaug, L. M. Swanson, T. L. Waldo, and C. E. Worcester, 1993, Tank Waste Technical Options Report, WHC-EP-0616, Westinghouse Hanford Company, Richland, Washington.

Boomer, K. D., J. M. Colby, T. W. Crawford, J. S. Garfield, J. D. Galbraith, C. E. Golberg, C. E. Leach, D. E. Mitchell, F. D. Nankani, E. J. Slaathaug, L. M. Swanson, T. L. Waldo, and C. M. Winkler, 1994, Tank Waste Remediation System Facility Configuration Study, WHC-SD-WM-ES-295, Westinghouse Hanford Company, Richland, Washington.

Colburn, R. P., 1995, Identification of Potential Transuranic Waste Tanks At The Hanford Site, WHC-SD-WM-ES-331, Westinghouse Hanford Company, Richland, Washington.

Crawford, T. C., 1995, Alternatives for High-Level Waste Forms, Containers, and Container Processing Systems, WHC-SD-WM-ES-348, prepared by Fluor Daniel Inc., Irvine, California, for Westinghouse Hanford Company, Richland, Washington.

Crawford, T. W. and A. F. Manuel, 1996, Technical Feasibility of Transuranic Tank Waste Processing in High-Level Waste Vitrification Facility, WHC-SD-WM-ES-386, Westinghouse Hanford Company, Richland, Washington.

DOE/CAO, 1995, Transuranic Waste Baseline Inventory, Rev. 2, Volume 1, DOE/CAO-95-1121, U.S. Department of Energy, Washington, D.C.

DOE-EM 1995, Waste Isolation Pilot Plant Overview, presentation by Douglas Tonkay, Transuranic Waste System Manager, Office of Waste Isolation Pilot Plant, Environmental Management, U.S. Department of Energy, Washington, D.C. 
WHC-SD-WM-ES-368

Revision 0

DOE-RW, 1993, Estimates for Disposal of Hanford Single-Shell Tank Waste in a Geologic Repository, Letter from H. H. Brandt, Director, Program Control and Administration Division, DOE-RW-133, to J. Tseng, Acting Director, Tank Waste Remediation System Division, EM-361, U.S. Department of Energy, Washington, D.C.

DOE-RW, 1995, Analysis of the Total System Life-Cycle Cost of the Civilian Radioactive Waste Management Program, DOE/RW-0479, U. S. Department of Energy Office of Civilian Radioactive Waste Management, Washington, D.C.

Ecology, DOE, and EPA, 1994, Hanford Federal Facility Agreement and Consent Order, as amended, Washington State Department of Ecology, U.S. Environmental Protection Agency, and the U.S. Department of Energy, Olympia, Washington.

Glass Chemistry Workshop, 1995, Glass Chemistry Workshop held August 4, 1995 to Determine Glass Component Limits for use in the INSIGHT Model, Technical Experts attending: A. L. Boldt, R. P. Colburn, B. A. Higley, S. L. Lambert, J. W. Shade, and C. E. Wilson, III, of Westinghouse Hanford Company, and X. Feng, P. R. Hrma, H. Li, and J. D. Vienna of Battelle Pacific Northwest National Laboratories, Richland, Washington.

Keeney, R. L., and D. von Winterfeldt, 1996, Value-Based Performance Measures for Hanford Tank Waste Remediation System Program, PNNL-10946, Battelle Pacific Northwest National Laboratory, Richland, Washington.

Kinzer, J. E., 1996, Tank Waste Remediation System (TWRS) Systems Requirements Review Action Plan, 95-TWR-129, Letter to Dr. A. L. Trego, Westinghouse Hanford Company (September 28, 1996), U.S. Department of Energy, Richland Operations Office, Richland, Washington.

Kosiancic, E. J., 1996, Remote Handled Transuranic Volume Estimates From Tank Waste Remediation System, Letter to D. D. Wodrich April 1, 1996, Westinghouse Hanford Company, Richland, Washington.

McConville, M. C. and M. E. Johnson, 1995, Decision Analysis Model for Assessment of Tank Waste Remediation System Waste Treatment Strategies, WHC-EP-0874, Westinghouse Hanford Company, Richland, Washington.

Orme, R. M., 1995, TWRS Process Flowsheet, WHC-SD-WM-TI-613, Rev. 1, Westinghouse Hanford Company, Richland, Washington.

Slaathaug, E. J., 1995, Tri-Party Agreement Alternative Engineering Data Package for the Tank Waste Remediation System Environmental Impact Statement, WHC-SD-WM-EV-104, Westinghouse Hanford Company, Richland, Washington. 
Slaathaug, E. J., W. A. Peiffer, and K. D. Boomer, 1995, Determine Waste Separations Process Trade Study, WHC-SD-WM-ES-356, Rev.0, Westinghouse Hanford Company, Richland, Washington.

WHC, 1992, Hanford Waste Vitrification Plant Technical Data Package, Volume 2, WHC-SD-HWV-DP-001, Westinghouse Hanford Company, Richland, Washington.

WHC, 1995, Tank Waste Remediation System Fiscal-Year 1996 Multi-Year Program Plan W.B.S. 1.1, WHC-SP-1101 Rev. 1a Vol. 1, Westinghouse Hanford Company, Richland, Washington.

WSRC, 1995, High-Level Waste System Plan, Revision 5, HLW-OVP-95-0031, Westinghouse Savannah River Company, Aiken, South Carolina. 
WHC-SD-WM-ES-368

Revision 0

This page intentionally left blank. 
WHC-SD-WM-ES-368

Revision 0

\section{APPENDIX B}

\section{DETAILED LIFE-CYCLE COST SUMMARY}


WHC-SD-WM-ES-368

Revision 0

This page intentionally left blank.

B-2 


\section{APPENDIX B}

\section{DETAILED LIFE-CYCLE COST SUMMARY}

Given user specified input parameters such as tank waste inventories, process conditions (e.g. glass waste form, crystalline or non-crystalline, etc.), and cost basis, the INSIGHT model calculates "base case" values for several performance measures. During the calculation of individual "base case" values, the factors that influence cost differences between the reference case 1 , and all other cases are as follows. For cases $2 \mathrm{a}$ and $2 \mathrm{c}$, segregation of TRU waste increases the total glass volume as shown in Table B-1. The volume of blended TRU glass is limited by the zirconium oxide limit. The total glass volume increases due to the limited volume of other TRU tank waste available to dilute the large quantity of zirconium in neutralized cladding removal waste stored in tanks 241-AW-103 and 241-AW-105. The number of canisters increase due to the increased glass volume and since the RH-TRU canister volume is about 44 percent less than the HLW canister. In case $2 b$, the TRU glass volume is half that of cases $2 a$ and $2 c$ since the TRU crystalline waste form can accommodate a larger quantity of zirconium.

Table B-1. Immobilized High-Level Waste and Transuranic Waste Volumes

\begin{tabular}{|l|c|c|c|c|c|}
\hline \multicolumn{2}{|c|}{} & $\begin{array}{c}\text { Case 1 } \\
\text { TWRS Process } \\
\text { Flowsheet, Rev. 1 }\end{array}$ & $\begin{array}{c}\text { Case 2a } \\
\text { Segregated } \\
\text { TRU Waste }\end{array}$ & $\begin{array}{c}\text { Case 2b } \\
\text { Segregated TRU } \\
\text { Waste, Crystalline } \\
\text { TRU Waste Form }\end{array}$ & $\begin{array}{c}\text { Case 2c } \\
\text { Segregated } \\
\text { TRU Waste, } \\
10.7 \text { MT/d } \\
\text { Melter }\end{array}$ \\
\hline $\begin{array}{l}\text { Figh-level } \\
\text { waste }\end{array}$ & $\begin{array}{c}\text { Containers } \\
\left(1.26 \mathrm{~m}^{3}\right)\end{array}$ & 7,120 & 6,550 & 6,550 & 6,550 \\
\cline { 2 - 6 } & Volume $\left(\mathrm{m}^{3}\right)$ & 8,970 & 8,250 & 8,250 & 8,250 \\
\hline \multirow{2}{*}{$\begin{array}{l}\text { Transuranic } \\
\text { waste }\end{array}$} & $\begin{array}{c}\text { Containers } \\
\left(0.71 \mathrm{~m}^{3}\right)\end{array}$ & $\mathrm{N} / \mathrm{A}$ & 1,850 & 925 & 1,850 \\
\cline { 2 - 6 } & Volume $\left(\mathrm{m}^{3}\right)$ & $\mathrm{N} / \mathrm{A}$ & 1,310 & 660 & 1,310 \\
\hline $\begin{array}{l}\text { Total } \\
\text { HLW/TRU } \\
\text { waste volume }\end{array}$ & Volume $\left(\mathrm{m}^{3}\right)$ & 8,970 & 9,560 & 8,910 & 9,560 \\
\hline
\end{tabular}

The increased number of canisters increases the vitrification and retrieval operating duration in cases $2 \mathrm{a}, \mathrm{b}$, and $\mathrm{c}$ as indicated by higher operating costs shown in Table B-2. The HLW facility capital cost increases about $\$ 100$ million (1995 dollars) for Case $2 \mathrm{c}$ to account for the increase plant capacity as shown in Table B-3. The HLW facility capital cost increases about $\$ 2$ million (1995 dollars) for Cases $2 a, 2 b, 2 c$ to account for two different canister sizes (Crawford 1996). A longer operating duration results in increased replacement melters and their associated cost. Interim storage costs decrease with segregated TRU waste 
because no dedicated interim storage is provided for TRU waste. The RH-TRU waste canisters would be temporarily stored in HLW interim storage space since the TRU is assumed to be shipped to WIPP within a year of immobilization.

Table B-2. Expense Cost Breakdown (Millions of 1995 Dollars).

\begin{tabular}{|c|c|c|c|c|}
\hline & $\begin{array}{c}\text { Case 1, } \\
\text { TWRS Process } \\
\text { Flowsheet } \\
\text { (Orme 1995) }\end{array}$ & $\begin{array}{c}\text { Case 2a, } \\
\text { Segregated } \\
\text { TRU Waste }\end{array}$ & $\begin{array}{c}\text { Case 2b } \\
\text { Segregated TRU } \\
\text { Waste, Crystalline } \\
\text { Waste Form }\end{array}$ & $\begin{array}{c}\text { Case 2c Segregated } \\
\text { TRU Waste, } \\
\text { 10.7 MT/d Melter }\end{array}$ \\
\hline Operating expense & 2,090 & 2,408 & 2,177 & 870 \\
\hline Labor & 790 & 932 & 829 & 389 \\
\hline Consumables & 365 & 389 & 363 & 79 \\
\hline Containers & 71 & 79 & 912 & 198 \\
\hline $\begin{array}{c}\text { Double-shell tank } \\
\text { retrieval operations }\end{array}$ & 186 & 1,008 & 180 & 791 \\
\hline Startup training & 742 & 743 & 743 & 3,190 \\
\hline $\begin{array}{l}\text { Decontamination and } \\
\text { decommissioning }\end{array}$ & 3,012 & 3,331 & 3,100 & \\
\hline Total expense cost & & & & 73 \\
\hline
\end{tabular}

$\mathrm{TRU}=$ Transuranic

TWRS $=$ Tank Waste Remediation System

Table B-3. Capital Cost Breakdown (Millions of 1995 Dollars).

\begin{tabular}{|l|c|c|c|c|}
\hline & $\begin{array}{c}\text { Case 1 } \\
\text { TWRS Process } \\
\text { Flowsheet, Rev. 1 }\end{array}$ & $\begin{array}{c}\text { Case 2a } \\
\text { Segregated TRU } \\
\text { Waste }\end{array}$ & $\begin{array}{c}\text { Case 2b } \\
\text { Segregated TRU } \\
\text { Waste, Crystalline } \\
\text { TRU Waste Form }\end{array}$ & $\begin{array}{c}\text { Case 2c } \\
\text { Segregated TRU } \\
\text { Waste, 10.7 } \\
\text { MT/d Melter }\end{array}$ \\
\hline Facility Capital Cost & 1,873 & $1,875^{\prime}$ & $1,875^{\mathrm{a}}$ & $1,975^{\mathrm{a}}$ \\
\hline Replacement Melters & 195 & 234 & 195 & 195 \\
\hline Interim Storage & 636 & 530 & 530 & 530 \\
\hline Total Capital Cost & 2,705 & 2,640 & 2,600 & 2,700 \\
\hline
\end{tabular}

The HLW facility capital cost increases about $\$ 2$ million (1995 dollars) for cases $2 a, 2 b, 2 c$ to account for two different canister sizes (Crawford 1996). 
HLW disposal costs decrease proportionally with the amount of TRU waste sent to WIPP as shown in Table B-4. TRU disposal costs are very minor compared to the total life cycie cost. The total life cycle cost differences between cases 1 and $2 \mathrm{a}$ or $2 \mathrm{c}$ are negligible. Cost savings in disposal costs are offset by additional operating costs (case 2a) or capital cost (case 2c). Total life cycle costs excluding disposal cost (Table B-5) indicate a $\$ 200$ million (1995 dollars) penalty for segregating TRU waste under the conditions of cases $2 \mathrm{a}$ and $2 \mathrm{c}$. Although case $2 \mathrm{~b}$ has potential of saving a few hundred million dollars, the incremental cost of developing, constructing, and operating a steep sloped bottom pour melter required to produce the crystalline waste form is not included in the estimate and would be expected to offset a portion of the potential savings.

Table B-4. Disposal Cost Breakdown (Millions of 1995 Dollars)

\begin{tabular}{|c|c|c|c|c|}
\hline & $\begin{array}{c}\text { Case 1, TWRS } \\
\text { Process Flowsheet } \\
\text { (Orme 1995) }\end{array}$ & $\begin{array}{c}\text { Case 2a, } \\
\text { Segregated TRU } \\
\text { Waste }\end{array}$ & $\begin{array}{c}\text { Case 2b, } \\
\text { Segregated TRU } \\
\text { Waste, Crystalline } \\
\text { TRU Waste Form }\end{array}$ & $\begin{array}{c}\text { Case 2c } \\
\text { Segregated TRU } \\
\text { Waste, 10.7 MT/d } \\
\text { Melter }\end{array}$ \\
\hline $\begin{array}{c}\text { Repository disposal } \\
\text { cost }\end{array}$ & 2,788 & 2,565 & 2,565 & 2,565 \\
\hline WIPP disposal cost & N/A & 55 & 28 & 55 \\
\hline Total disposal cost & 2,788 & 2,620 & 2,593 & 2,620 \\
\hline $\begin{array}{l}\text { TRU } \\
\text { TWRS }=\end{array}$ & $\begin{array}{l}\text { Transuranic } \\
\text { Tank Waste Remediation System }\end{array}$
\end{tabular}


WHC-SD-WM-ES-368

Revision 0

Table B-5. Life-Cycle Cost Breakdown (Millions of 1995 Dollars)a

\begin{tabular}{|l|c|c|c|c|}
\hline & $\begin{array}{c}\text { Case 1, } \\
\text { TWRS Process } \\
\text { Flowsheet (Orme } \\
1995)\end{array}$ & $\begin{array}{c}\text { Case 2a, } \\
\text { Segregated TRU } \\
\text { Waste }\end{array}$ & $\begin{array}{c}\text { Case 2b;" } \\
\text { Segregated TRU } \\
\text { Waste, } \\
\text { Crystalline TRU } \\
\text { Waste Form }\end{array}$ & $\begin{array}{c}\text { Case 2c, } \\
\text { Segregated TRU } \\
\text { Waste, 10.7 MT/d } \\
\text { Melter }\end{array}$ \\
\hline Expense cost & 3,012 & 3,331 & 3,100 & 3,190 \\
\hline Capital cost & 2,705 & 2,640 & 2,600 & 2,700 \\
\hline $\begin{array}{l}\text { Life-cycle cost excluding } \\
\text { disposal }\end{array}$ & 5,717 & 5,970 & 5,699 & 5,891 \\
\hline Disposal cost & 2,788 & 2,620 & 2,593 & 2,620 \\
\hline Total life-cycle cost & 8,505 & 8,591 & 8,292 & 8,512 \\
\hline
\end{tabular}

TRU $=$ Transuranic

TWRS $=$ Tank Waste Remediation System

${ }^{2}$ Costs shown here represent high-level and transuranic waste processing only. The total life-cycle cost does not include single-shell tank retrieval, pretreatment, or lowactivity waste processing.

${ }^{b}$ Case $2 \mathrm{~b}$ requires melter and glass form development which is not included in the life-cycle cost estimate.

Table B-6 summarizes the results of the life-cycle cost probabilistic evaluation. Lifecycle cost values are reported as a range, with the low value representing a 20 percent probability and the high value representing an 80 percent probability. The values were determined from the life-cycle cost probability distribution charts, Figures A-5 and A-10. It can be seen from Table B-6 and Figure A-5 that the variations in life-cycle cost including disposal cost among the four case studies are negligible. The probability distribution chart for life-cycle cost excluding life-cycle cost (Figure A-10) shows a constant variation between cases 1 and $2 b$ and cases $2 a$ and $2 c$, with cases 1 and $2 b$ always costing less. However, when compared to the cumulative probability distribution curves for life-cycle cost including disposal cost (Figure A-5), it can be seen that the uncertainties associated with disposal costs cause the variations among the cases to become less distinctive. 
WHC-SD-WM-ES-368

Revision 0

Table B-6. Life-Cycle Cost Probabilistic Summary (Millions of 1995 Dollars)."

\begin{tabular}{|l|c|c|c|c|}
\hline & \multicolumn{2}{|c|}{$\begin{array}{c}\text { Life-cycle cost including } \\
\text { disposal } \text { cost }^{\mathrm{b}}\end{array}$} & \multicolumn{2}{c|}{$\begin{array}{c}\text { Life-cycle cost excluding } \\
\text { disposal cost }\end{array}$} \\
\cline { 2 - 5 } & $\begin{array}{c}20 \% \\
\text { cumulative } \\
\text { probability }\end{array}$ & $\begin{array}{c}80 \% \\
\text { cumulative } \\
\text { probability }\end{array}$ & $\begin{array}{c}20 \% \\
\text { cumulative } \\
\text { probability }\end{array}$ & $\begin{array}{c}80 \% \\
\text { cumulative } \\
\text { probability }\end{array}$ \\
\hline $\begin{array}{l}\text { Case 1, TWRS Process } \\
\text { Flowsheet } \text { (Orme 1995) }\end{array}$ & 8,250 & 9,900 & 5,500 & 6,600 \\
\hline $\begin{array}{l}\text { Case 2a, Segregated } \\
\text { TRU Waste }\end{array}$ & 8,500 & 10,100 & 5,800 & 6,900 \\
\hline $\begin{array}{l}\text { Case 2b, }{ }^{c} \text { Segregated } \\
\text { TRU Waste, } \\
\begin{array}{l}\text { Crystalline TRU Waste } \\
\text { Form }\end{array}\end{array}$ & 8,250 & 9,800 & 5,600 & 6,700 \\
\hline $\begin{array}{l}\text { Case 2c, Segregated } \\
\text { TRU Waste, } \\
\text { 10.7 MT/d Melter }\end{array}$ & 8,500 & 10,200 & 5,750 & 6,900 \\
\hline
\end{tabular}

TRU = Transuranic

TWRS $=$ Tank Waste Remediation System

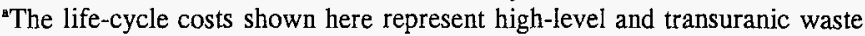
processing only. The costs do not include single-shell tank retrieval, pretreatment, or low-activity waste processing.

${ }^{b}$ Cumulative probabilities of 20 and 80 percent are representative of the range shown on the life-cycle cost including disposal probability distribution chart Figure A-5.

${ }^{c}$ Cumulative probabilities of 20 and 80 percent are representative of the range shown on the life-cycle cost excluding disposal probability distribution chart Figure A-10.

${ }^{\mathrm{d}}$ Case $2 \mathrm{~b}$ requires melter and glass form development which is not included in the life-cycle cost estimate. 
WHC-SD-WM-ES-368

Revision 0

This page intentionally left blank. 


\section{DISTRIBUTION SHEET}

\begin{tabular}{|c|c|c|c|c|c|}
\hline \multirow{2}{*}{$\begin{array}{l}\text { To } \\
\text { Distribution }\end{array}$} & \multirow{2}{*}{\multicolumn{3}{|c|}{$\begin{array}{l}\text { From } \\
\text { T. W. Crawford }\end{array}$}} & \multicolumn{2}{|l|}{ Page 1 of 1} \\
\hline & & & & \multicolumn{2}{|c|}{ Date $7 / 25 / 96$} \\
\hline \multirow{2}{*}{\multicolumn{4}{|c|}{$\begin{array}{l}\text { Project Titie/Work Order } \\
\text { Decision Document for Transuranic Tank Waste Disposal, } \\
\text { WHC-SD-WM-ES-368, Rev. } 0 \text {. }\end{array}$}} & \multicolumn{2}{|c|}{ EDT No. 608739} \\
\hline & & & & \multicolumn{2}{|l|}{ ECN No. } \\
\hline Name & MSIN & $\begin{array}{l}\text { Text } \\
\text { With All } \\
\text { Attach. }\end{array}$ & Text Only & $\begin{array}{l}\text { Attach.l } \\
\text { Appendix } \\
\text { Only }\end{array}$ & $\begin{array}{c}\text { EDT/ECN } \\
\text { Only }\end{array}$ \\
\hline
\end{tabular}

Central Files

DOE Reading Room

$\begin{array}{ll}\text { A3-88 } & x \\ H 2-53 & x\end{array}$

U.S. Department of Energy-Richland Operations office

C. P. Bader

D. D. Button

R. Carreon

R. A. Gilbert

J. K. Mcclusky

W. J. Taylor

H. J. Wacek

D. D. Wodrich

$\begin{array}{ll}S 7-50 & X \\ K 6-51 & X \\ K 6-51 & X \\ K 6-51 & X \\ S 7-54 & X \\ K 6-51 & X \\ S 7-54 & X \\ S 7-50 & X\end{array}$

Westinghouse Hanford Company

R. D. Claghorn

R. P. Colburn

T. W. Crawford (3)

J. S. Garfield

R. L. Gibby

J. W. Hales (2)

J. 0. Honeyman

M. E. Johnson

E. J. Kosiancic

C. M. McConvilie (3)

R. J. Murkowski

W. J. Powell

R. W. Powell

P. S. Schaus

D. J. Washenfelder

H5-49 X

H5-27 X

H5-49 X

H5-49 X

H5-27 X

81-17

G3-21

G3-21

H5-6I

H5- 49

H5- 03

H5- 49

H4-14

G3-21

H5-27

$x$
$x$

$x$

$x$

$x$

$X$
$X$

$x$

$x$

ICF Kaiser Hanford

S. K. Baker

H5-49 X 